Published in: Journal of Urban Economics, 2021, Article

\title{
Old sins cast long shadows: The Long-term impact of the resettlement of the Sudetenland on residential migration
}




\section{Old sins cast long shadows: The Long-term impact of the resettlement of the Sudetenland on residential migration}

\section{Abstract}

We analyze the long-term impact of the resettlement of the Sudetenland after World War II on residential migration. This event involved expulsion of ethnic Germans and almost complete depopulation of an area of a country and its rapid resettlement by 2 million Czech inhabitants. Results based on nearest neighbor matching and regression discontinuity design show a higher population churn in resettled areas that continues today. The populations in resettled areas and in the remainder of the country share similar values and do not differ statistically in terms of their propensity to give donations, attend social events, and participate in voluntary work. However, we observe that resettled settlements have fewer local club memberships, lower turnout in municipal elections, and less frequently organized social events. This finding indicates substantially lower local social capital in the resettled settlements that is likely to have caused higher residential migration. This explanation is consistent with theoretical models of the impact of social capital on migration decisions.

\footnotetext{
Masaryk University

Faculty of Economics and Administration
}

Authors:

Martin Guzi (ORCID: 0000-0001-9936-3175) / Masaryk University

Peter Huber (ORCID: 0000-0001-6263-6395) / Austrian Institute for Economic Research

Štěpán Mikula (ORCID: 0000-0003-1725-8561) / Masaryk University

Contact: stepan.mikula@econ.muni.cz

Creation date: 2019-07

Revision date: 2023-01

Keywords: Migration, Social Capital, Sudetenland

JEL classification: N44, Z10, R23, J15

Citation:

Guzi, M., Huber, P., Mikula, Š. (2019). Old sins cast long shadows: The Long-term impact of the resettlement of the Sudetenland on residential migration. MUNI ECON Working Paper n. 2019-07.

Brno: Masaryk University. https://doi.org/10.5817/WP_MUNI_ECON_2019-07 


\title{
Old sins cast long shadows: The long-term impact of the resettlement of the Sudetenland on residential migration*
}

\author{
Martin Guzi, Peter Huber, and Štěpán Mikula ${ }^{\dagger}$
}

July 31,2019

We analyze the long-term impact of the resettlement of the Sudetenland after World War II on residential migration. This event involved expulsion of ethnic Germans and almost complete depopulation of an area of a country and its rapid resettlement by 2 million Czech inhabitants. Results based on nearest neighbor matching and regression discontinuity design show a higher population churn in resettled areas that continues today. The populations in resettled areas and in the remainder of the country share similar values and do not differ statistically in terms of their propensity to give donations, attend social events, and participate in voluntary work. However, we observe that resettled settlements have fewer local club memberships, lower turnout in municipal elections, and less frequently organized social events. This finding indicates substantially lower local social capital in the resettled settlements that is likely to have caused higher residential migration. This explanation is consistent with theoretical models of the impact of social capital on migration decisions.

Keywords: Migration, Social Capital, Sudetenland

JEL Codes: N44, Z10, R23, J15

*Financial support by the Czech Science Foundation (grant No. 18-16111S) is gratefully acknowledged. We thank Alžběta Hanáčková, Barbora Kuklová and Marek Breza for excellent research assistance and Martin Halla, Benjamin Elsner, Tomáš Dvořák and Peter Egger, as well the participants of the 2017 research seminars at the University of Economics in Prague and the University of Stavanger, 2017, the $10^{\text {th }}$ Geoffrey J.D: Hewings Regional Economics Workshop in Vienna, the 2018 Slovak Economic Association Meeting, the 2018 Scottish Economic Society Annual Conference, the 2019 ISWG workshop in Vienna, the 2019 GFR Winterseminar in Matrei and the 2019 Annual Meeting of the Austrian Economic Association, the $33^{\text {rd }}$ Annual Conference of the European Society for Population Economics in Bath for helpful comments.

${ }^{\dagger}$ Martin Guzi: Department of Public Economics, Masaryk University. Address: Lipová 41a, Brno, Czech Republic. Email: martin.guzi@econ.muni.cz, Peter Huber: Austrian Institute for Economic Research. Address: Arsenal Objekt 20, Wien, Austria. Email: peter.huber@wifo.ac.at, Štěpán Mikula: Corresponding author. Department of Economics, Masaryk University. Address: Lipová 41a, Brno, Czech Republic. Phone: +420 724512 946. Email: stepan.mikula@econ.muni.cz. 


\section{Introduction}

A growing body of economic and political science research documents that the instances of forced emigration and mass murder that marked $20^{\text {th }}$ century European history had long-lasting and sizeable effects on the political attitudes (Acemoglu et al. 2011; Grosfeld et al. 2013), economic and educational outcomes (Acemoglu et al. 2011; Akbulut-Yuksel and Yuksel 2015) and scientific achievements (Waldinger 2010, 2011) of the affected regions. This evidence is mostly based on the mass murder and forced emigration of Jews in World War II (WWII) and suggests that these factors had substantially more long-lasting and sizeable effects than found in the related literature on the destruction of physical capital (Brakman et al. 2004; Waldinger 2016).

This paper adds to this literature by studying the long-term impact of the post-WWII mass expulsion of ethnic Germans from the area of today's Czech Republic (the so-called Sudetenland) on residential migration. Different from the literature, we study a case of an almost complete depopulation of an area and its rapid resettlement by another population group. This large-scale resettlement is particularly well suited to identify the effects of the complete destruction of the social structure of a community while leaving the physical capital intact. This is due to the size of the population exchange, which unlike the Holocaust affected all social groups in a region alike, the extraordinary speed with which ethnic Germans had to leave; the rapid resettlement that occurred in the follow-up of the expulsion; and the fleeing population having to leave behind virtually all their belongings which were seized by the new settlers.

This paper, therefore, also contributes to the mostly historical literature on this resettlement. In this literature, Daněk (1995) shows that 50 years after resettlement, the population in districts at least partially located in the Sudetenland is younger, less educated, more secularized, and ethnically more diverse compared with other districts of today's Czech Republic. By contrast, Testa (2019), in the paper most similar to this one, uses settlement-level data from the 2011 census and a spatial regression discontinuity design based on the borders drawn during the German occupation of the Czech territories from 1938 to 1945 (the so-called Munich Agreement line). He shows long-run effects of resettlement in population density, unemployment, sector composition, and educational attainment. In addition, using district-level data from several censuses since 1950, he finds evidence for higher emigration and immigration rates during communism among districts partially or completely located in the German Reich from 1938 to 1945 relative to adjacent districts.

We combine a unique settlement-level administrative dataset that includes all permanent residence changes in the years 1971 to 2015 with pre-WWII settlement-level data on the 
ethnic composition of settlements in 1930. This combination allows us to identify the causal effects of resettlement on residential migration by comparing settlements with more than $90 \%$ ethnic Germans in 1930 (which we refer to as new settlements) that were most strongly affected by resettlement to settlements with less than $10 \%$ ethnic German residents in 1930 (referred to as old settlements) and analyze the dynamics of the causal effects of resettlement on residential migration.

We employ two complementary identification strategies. First, we use a matching strategy to compare residential migration between matched settlements similar in size and located in geographical proximity. Second, we use a regression discontinuity (RD) design where the inference is based on a precise definition of the border between ethnic Germanand Czech-dominated areas before WWII. The results obtained from both identification strategies are essentially identical and indicate that resettlement led to a long-lasting increase in residential migration from and to the new settlements that survived such important institutional changes as the transition from a planned to a market economy, the dissolution of Czechoslovakia and accession to the European Union, and the many economic changes that occurred in the Czech Republic in that period. Thus, even at the end of our observation period, in 2015 (i.e., 70 years after the resettlement), emigration and immigration rates in settlements were still 0.4 percentage points higher (relative to a baseline of $2.3 \%$ for emigration and $2.9 \%$ for immigration) than among the comparison settlement. In addition, the effects of resettlement on emigration dominate over those on immigration at the beginning of the period studied, such that net immigration from new settlements initially increased as well. This effect, however, levels off to zero after the mid-1980s.

We examine two alternative causal mechanisms that could potentially explain this long-term impact of resettlement. First, the impetus for higher residential migration may be population sorting, whereby individuals moving to the Sudetenland in the postwar period were more mobile groups among the Czech population at the time, and the higher propensity to move is transmitted across generations. Second, the impact of resettlement could result from the destruction of social capital and its impact on migration decisions. By analyzing auxiliary datasets we provide evidence in favor of the latter mechanism. We find that populations in the treated and comparison settlements share similar values and do not differ statistically in terms of their inclination to give donations, attend social events, and participate in voluntary work. People in treated settlements, however, have fewer local club memberships, less frequently organized social events, and lower turnout rates in municipal elections. We therefore argue that lower social capital in treated settlements is likely to have caused persistently higher residential migration. This explanation accords with many of the descriptions of these settlements by historians (Glassheim 2006; Vaněk 1996; Čapka 
et al. 2005; Spurný 2011; Matějka 2008) and is consistent with theoretical models of the impact of social capital on migration decisions (e.g., David et al. 2010; Bräuninger and Tolciu 2011).

The remainder of the paper is structured as follows. Section two provides the historical background of the resettlement. Section three presents the data. Section four introduces the identification strategies used. Section five describes the results. Section six discusses the mechanism driving the results, and section seven concludes.

\section{Historical background}

\subsection{Ethnic Germans in the Czech Republic}

Germans had been settling in the area of today's Czech Republic since the $13^{\text {th }}$ century. Compared with the Jewish population studied in the literature, ethnic Germans in the Czech territory never belonged to a discriminated group (e.g., Alexander 2008; Meixner 1988). During the Austro-Hungarian Empire, of which today's Czech Republic was a part of from the $16^{\text {th }}$ century to 1918 , ethnic Germans tended to be more privileged relative to the Czech population partly because they spoke the official language of the empire. They were, however, clearly segregated from the Czech population and mainly resided in the northern, western, and southern parts of today's Czech Republic, the so-called Sudetenland ${ }^{1}$ (Figures 1 and 2) which, except for a short period from 1938 to 1945 under German occupation, was always administered in the same manner as the rest of the country.

Ethnic tensions between Czechs and Germans arose in the second half of the $19^{\text {th }}$ century and continued after the break-up of the Austro-Hungarian Empire, when ethnic Germans comprised $29.5 \%$ of the population of today's Czech Republic, according to the last pre-WWII population census in 1930 (see CZSO 2014). Historical records document a number of complaints from German representatives during the interwar period inter alia about limited access to employment in the state bureaucracy, the closing of German language schools, and the asymmetric impact of land reforms in the 1920s. Yet, according to many accounts (e.g., Glassheim 2000) minority policy in Czechoslovakia was one of the most liberal in Central and Eastern Europe at the time. Ethnic tensions severely intensified only with the economic crisis in 1933 and the increasing popularity of German nationalist political parties. Under the Munich Accord in 1938 the Sudetenland was annexed by the German Reich and remained under German rule until the end of WWII.

1. The word Sudetenland is used in common language to denote the territories settled by the ethnic Germans before World War II. 
Figure 1: Share of ethnic Germans in settlements in 1930

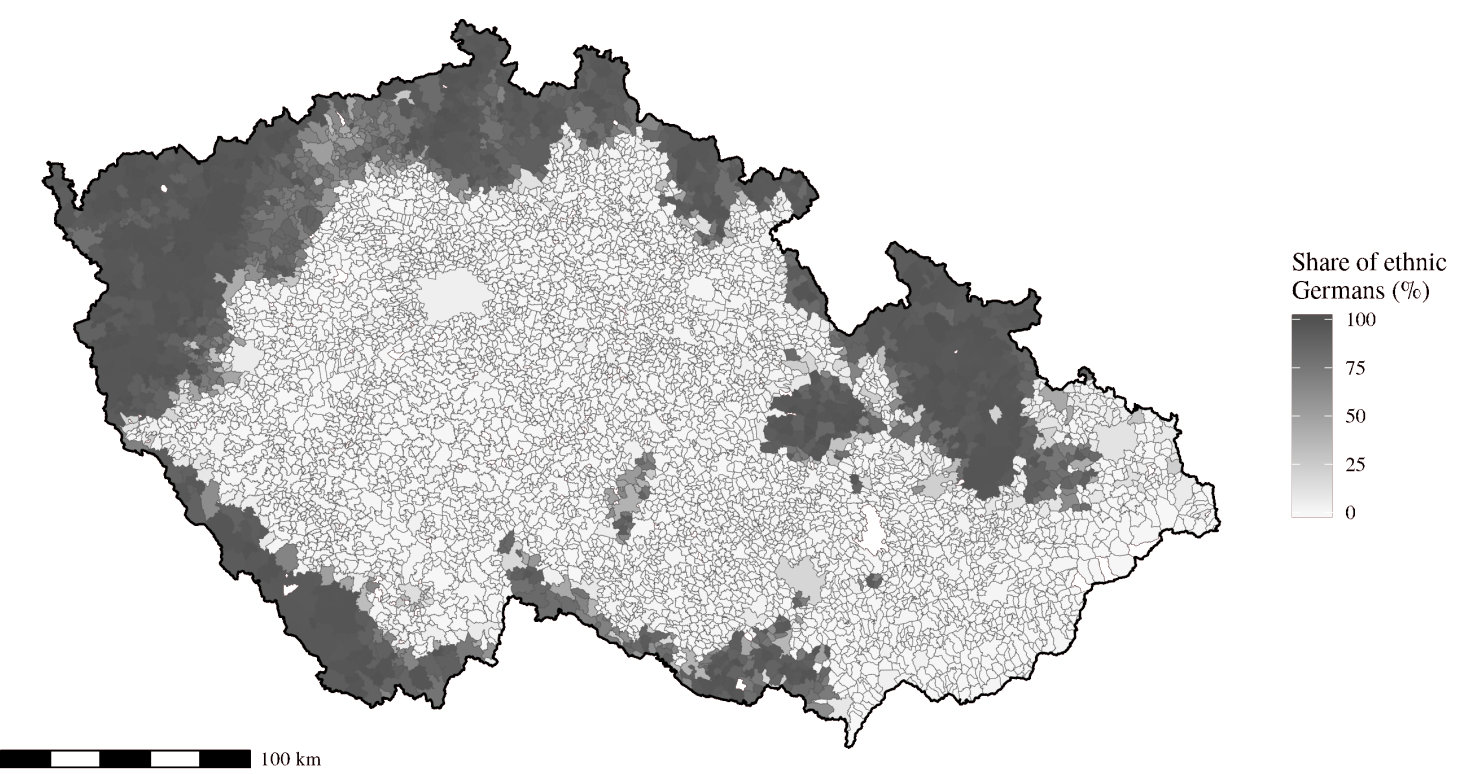

Source: CZSO, own calculations.

Note: The ethnic German population is defined according to the primarily spoken language. The 1930 settlement-level data on ethnic Germans is harmonized with 6,168 settlements defined in the 2011 census by using matching rules provided by the CZSO. 
Figure 2: Distribution of settlements by the share of ethnic Germans in 1930

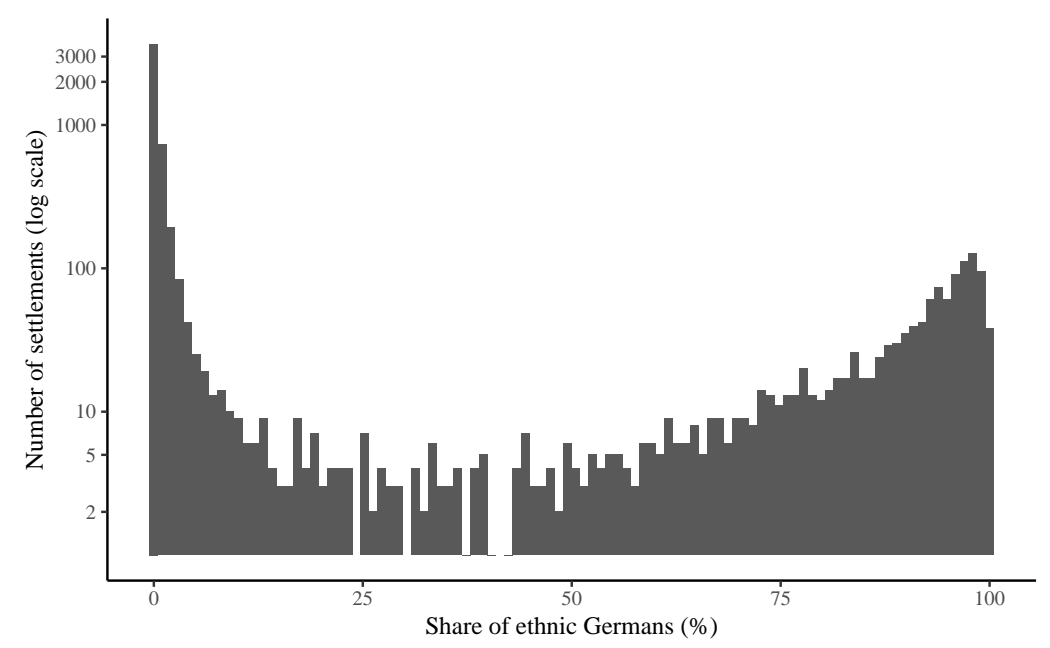

Source: CZSO, own calculations.

Note: The ethnic German population is defined according to the primarily spoken language. The 1930 settlement-level data on ethnic Germans is harmonized with 6,168 settlements defined in the 2011 census by using matching rules provided by the CZSO.

\subsection{Expulsion of the Germans and resettlement}

In the aftermath of WWII, the ethnic Germans were held responsible for the Nazi atrocities and considered traitors. This perspective ultimately led to their expulsion, which started with the end of WWII in May 1945 and proceeded in two waves. The initial phase, referred to as "wild expulsion", was poorly organized and controlled within a vague legal framework. Up to 800,000 Germans left the country in this phase until the autumn of 1945 (Wiedemann 2016). The second more organized phase continued from January to October 1946 and followed the agreements of the Potsdam Conference. The mass transportation during the second phase reduced the prewar population of ethnic Germans of 3 million to 200 to 300 thousand (Gerlach 2017). The share of ethnic Germans in the Czech population decreased from $29.5 \%$ (based on the 1930 census) to $1.8 \%^{2}$ based on the first postwar census in 1950 (CZSO 2014).

The process of resettlement occurred in parallel with the expulsion. Initially, people were encouraged through newspapers and radio broadcasting to seize German properties and were supported by Czech soldiers, militias, and security forces (Glassheim 2000). During the wild expulsion, between 500,000 and 900,000 new settlers arrived in the

2. Data on ethnicity from the 1930 and 1950 censuses are not fully comparable due to methodological changes. Nevertheless, estimates of historians are very similar to the 1950 census data. According to Staněk (1991) there were 216,545 inhabitants of non-Slavic origin in 1947. The remaining Germans were also subjected to an internal relocation policy (Dvořák 2013). 
Sudetenland. ${ }^{3}$ The massive population inflows of ethnic Czechs continued until the spring of 1947, and more modest migration continued until the early 1950s (Wiedemann 2016). According to Gerlach (2010), almost 2 million new ethnic Czech settlers had arrived to Sudetenland by May 1947, while earlier estimates by Radvanovský (2001) suggest an influx of 1.5 million over the first 2 years of resettlement.

\subsection{Characteristics of settlers}

For the Czech citizens the resettlement process offered a unique opportunity to improve their economic and social status by acquiring a house and small piece of land (the official limit was 0,13 square kilometers) ${ }^{4}$ and thus also seizing the expellees' other property, ${ }^{5}$ obtaining a better job, or becoming a national administrator ${ }^{6}$ of seized properties (Wiedemann 2016). The weak regulation (and often chaotic nature) of the resettlement process makes it difficult to map the socioeconomic characteristics of settlers. Wiedemann (2016), Čapka et al. (2005) and Školl (1983) characterize settlers as young, often married couples, landless persons, small farmers, second-born children (with low prospects for family inheritance), or individuals who had worked in the civil services or nonagricultural sector.

The resettlement policy aimed to attract people primarily from areas that were geographically proximal and climatically similar in order to increase the chances of settlers establishing economically and socially functional communities (Wiedemann 2016). Historic records document that settlers almost exclusively moved from other settlements of today's Czech Republic ${ }^{7}$ and over rather short distances. For example, Školl (1983) documents that only $16 \%$ of the settlers in Břeclav district moved less than $10 \mathrm{~km}$, and $39 \%$ moved more than $100 \mathrm{~km}$ (Figure A.1 and Table A.1 in the Appendix). Settlers likely moved in smaller groups, however. Detailed statistics on the original settlement of settlers in the Břeclav district reveal that $12 \%$ of settlers were from the same origin settlement

3. Radvanovský (2001) estimates that 514,515 settlers arrived in Sudetenland by September 16, 1945. Wiedemann (2016) claims that their numbers reached 696,554 by mid-October and 862,706 by the end of 1945.

4. Čapka et al. (2005) document that $91 \%$ of the settlers in the villages around Mikulov previously owned land with acreage less than 0.03 square kilometers, and the typical acreage redistributed to settlers around Mikulov was 0.05 to 0.08 square kilometers.

5. The expellees could keep $30 \mathrm{~kg}$ and later $50 \mathrm{~kg}$ of their belongings (excluding valuables) during the more organized phase of the expulsion (Gerlach 2017). The settlers had to pay for the acquired property. Prices were low, however. The price for land was set as the value of two yearly crops and the price of a house was 1-3 times the yearly rent. Ten percent of the total price was due at the time of property acquisition. The remainder was payable in the following 15 years. Settlers could pay in cash or kind and a substantial part of the liabilities was never paid (Wiedemann 2016).

6. This was a trustee who could manage an enterprise (or large farm) on behalf of the state with the prospect of becoming the owner (Gerlach 2017).

7. Školl (1983) notes that in the Břeclav district, located at the border with Slovakia and Austria, 90.3\% of settlers were Czech, 2.1\% were Slovak, and 7.6\% were of other nationalities (Table A.3 in the Appendix). 
and $29 \%$ of settlers originated from the four most important settlements (Table A.2 in the Appendix). Čapka et al. (2005) describe Sobotín in North Moravia as a settlement with a large group of settlers from the same original settlement, but even in this example, the settlers from the same original settlement comprise less than $20 \%$.

These major migratory movements resulted in two types of settlements. The old settlements were mainly inhabited by ethnic Czechs before WWII and were therefore not subject to expulsion and resettlement. The new settlements were mainly inhabited by ethnic Germans before WWII and thus lost most of their original population together with their human and social capital. The resettlement process brought new inhabitants to the emptied settlements who were allowed to seize the property left behind by the expellees but had to re-establish all social contacts anew.

\section{Data}

\subsection{Migration and population data}

We investigate how this resettlement affected the subsequent migration behavior in the affected settlements. The immigration and emigration rates as the key dependent variables of this analysis are taken from administrative records of permanent residence changes provided by the Czech Statistical Office (CZSO) for the period 1971 to $2015 .{ }^{8}$ These rates provide the number of movers from and to settlements as a percentage of the population on January 1.9 This data is highly reliable because residents of former Czechoslovakia (and of the current Czech Republic) are legally obliged to register changes of their permanent address. This registration also defines the constituency in municipal elections and associations with preferential access to local public services such as healthcare, elementary schools, kindergartens, and subsidized accommodations for university students.

We obtain the share of ethnic Germans in each settlement from the 1930 population census (the last census before WWII), in which ethnicity is defined according to the language primarily spoken in the household. ${ }^{10}$ We use this data to identify treatment and comparison settlements and to construct the ethnic border. From population censuses in the years 1980, 1991, 2001, and 2011 we obtain the age and education structure of settlements.

8. Data is available at www.czso.cz/csu/czso/databaze-demografickych-udaju-za-obce-cr. We have data for 6,168 settlements due to some records being lost prior to digitalization; this is an unbalanced panel. The baseline model is estimated with pooled data on all settlements, and we address concerns that relate to missing observations in the robustness analysis in Section 5.3.

9. Annual population data are obtained from the CZSO. We remove obvious outliers (i.e., the top $1 \%$ of emigration and immigration rates) from the data. In the robustness analysis in section 5.3 we show that the inclusion of outliers slightly increases the estimated effects.

10. Data from the 1930 census was digitalized by the authors (Appendix B). Matching rules provided by the CZSO were applied to harmonize settlements such as in the 2011 census. 
Table 1 presents descriptive statistics of the pooled sample. We report averages and standard errors of migration variables, population, and the share of ethnic Germans in 1930 separately for the new and old settlements. The emigration rates were on average higher in the 1970s and 1980s compared with later periods, and the immigration rates are more stable over time. Both emigration and immigration rates are consistently higher in the new settlements relative to old settlements throughout the observation period, but this difference narrows in later periods.

\subsection{Local social capital and values data}

We augment this data with administrative data on election turnout (i.e., the percentage of eligible voters who cast a ballot) in all free and voluntary municipal elections held in the Czech Republic provided by the CZSO and survey data on values, civic participation, and charitable activities collected in 2003 and 2004, respectively, and describe this data in detail in the Appendix of this paper. These survey data are, according to our review of the literature, the only publicly available data in the Czech Republic that allow us to examine shared norms and values at the settlement level. The 2003 survey (Majerová et al. 2003) was conducted in two waves. In the first wave, mayors of 1,324 settlements were asked about the frequency of events organized by local clubs and green activities. In the second wave, 1,287 residents in 223 settlements were asked about club membership, participation at locally organized events, donations, and volunteer work. The 2004 survey (Majerová et al. 2004) asked 1,518 respondents in 220 settlements about the importance of values in their life (i.e., nature and environment, a job, relationships, faith and spiritual values, hobbies, housing, friendship, family life and children, and material conditions).

\subsection{Geographical data}

Since our identification strategies require geographic information, we geocode all settlementlevel data using the reference points defined by the $\mathrm{CZSO}^{11}$ and obtain altitude and terrain roughness data for each settlement using remotely sensed elevation data from Shuttle Radar Topography Mission (SRTM) 1 Arc-Second Global. ${ }^{12}$ Altitude is measured as the elevation at the reference point. Terrain roughness is calculated as the average of terrain roughness around the reference point ${ }^{13}$ such that higher values indicate rougher terrain.

11. These are placed in the social center of settlements (i.e., typically in front of the town hall or church)

12. The SRTM data for the Czech Republic are transformed into approximately $30 \times 40$ meter tiles, which is the maximum homogeneous resolution available for the SRTM data of the Czech Republic. Terrain roughness is calculated as the mean of the absolute differences between the altitude of a tile and the altitudes of its eight surrounding tiles (Wilson et al. 2007).

13. We use a $1.6 \mathrm{~km}$ radius throughout because this is the median radius of settlements in the Czech Republic. 
Table 1: Descriptive statistics

\begin{tabular}{|c|c|c|c|c|c|}
\hline & \multirow[b]{3}{*}{ Period } & \multicolumn{3}{|c|}{ Settlements } & \multirow{2}{*}{$\begin{array}{c}\text { Difference } \\
\text { (2)-(3) }\end{array}$} \\
\hline & & All & New & Old & \\
\hline & & (1) & (2) & (3) & (4) \\
\hline Settlements (n) & & 6,168 & 751 & 4,808 & \\
\hline Share of ethnic Germans (\%) & 1930 & $\begin{array}{l}18.43 \\
(0.45)\end{array}$ & $\begin{array}{c}95.92 \\
(0.10)\end{array}$ & $\begin{array}{c}0.48 \\
(0.02)\end{array}$ & $95.43^{* * *}$ \\
\hline Population (n) & 1930 & $\begin{array}{r}1,725.54 \\
(172.51)\end{array}$ & $\begin{array}{r}1,997.30 \\
(117.27)\end{array}$ & $\begin{array}{c}1,319.73 \\
(202.09)\end{array}$ & $677.57^{* *}$ \\
\hline \multirow[t]{5}{*}{ Emigration rate $(\%)$} & 1971-1979 & $\begin{array}{l}3.50 \\
(0.008)\end{array}$ & $\begin{array}{c}5.05 \\
(0.03)\end{array}$ & $\begin{array}{l}3.19 \\
(0.008)\end{array}$ & $1.85^{* * *}$ \\
\hline & 1980-1989 & $\begin{array}{l}3.11 \\
(0.008)\end{array}$ & $\begin{array}{c}4.34 \\
(0.03)\end{array}$ & $\begin{array}{l}2.88 \\
(0.008)\end{array}$ & $1.46^{* * *}$ \\
\hline & 1990-1999 & $\begin{array}{l}2.44 \\
(0.006)\end{array}$ & $\begin{array}{c}3.12 \\
(0.02)\end{array}$ & $\begin{array}{l}2.29 \\
(0.007)\end{array}$ & $0.83^{* * *}$ \\
\hline & 2000-2009 & $\begin{array}{l}2.37 \\
(0.006)\end{array}$ & $\begin{array}{c}3.09 \\
(0.02)\end{array}$ & $\begin{array}{l}2.21 \\
(0.007)\end{array}$ & $0.88^{* * *}$ \\
\hline & 2010-2015 & $\begin{array}{l}2.51 \\
(0.008)\end{array}$ & $\begin{array}{c}3.26 \\
(0.03)\end{array}$ & $\begin{array}{c}2.34 \\
(0.008)\end{array}$ & $0.92^{* * *}$ \\
\hline \multirow[t]{5}{*}{ Immigration rate $(\%)$} & $1971-1979$ & $\begin{array}{l}2.38 \\
(0.009)\end{array}$ & $\begin{array}{c}3.38 \\
(0.03)\end{array}$ & $\begin{array}{l}2.14 \\
(0.009)\end{array}$ & $1.24^{* * *}$ \\
\hline & 1980-1989 & $\begin{array}{l}2.35 \\
(0.008)\end{array}$ & $\begin{array}{c}3.14 \\
(0.03)\end{array}$ & $\begin{array}{l}2.19 \\
(0.009)\end{array}$ & $0.95^{* * *}$ \\
\hline & 1990-1999 & $\begin{array}{l}2.41 \\
(0.008)\end{array}$ & $\begin{array}{c}3.21 \\
(0.03)\end{array}$ & $\begin{array}{c}2.24 \\
(0.009)\end{array}$ & $0.97^{* * *}$ \\
\hline & 2000-2009 & $\begin{array}{l}3.03 \\
(0.009)\end{array}$ & $\begin{array}{c}3.64 \\
(0.03)\end{array}$ & $\begin{array}{l}2.90 \\
(0.01)\end{array}$ & $0.74^{* * *}$ \\
\hline & 2010-2015 & $\begin{array}{l}3.05 \\
(0.01)\end{array}$ & $\begin{array}{c}3.53 \\
(0.03)\end{array}$ & $\begin{array}{c}2.94 \\
(0.01)\end{array}$ & $0.59^{* * *}$ \\
\hline \multirow[t]{5}{*}{ Net immigration rate $(\%)$} & $1971-1979$ & $\begin{array}{c}-1.12 \\
(0.01)\end{array}$ & $\begin{array}{c}-1.67 \\
(0.04)\end{array}$ & $\begin{array}{c}-1.05 \\
(0.01)\end{array}$ & $-0.62^{* * *}$ \\
\hline & 1980-1989 & $\begin{array}{c}-0.76 \\
(0.01)\end{array}$ & $\begin{array}{c}-1.20 \\
(0.03)\end{array}$ & $\begin{array}{l}-0.69 \\
(0.01)\end{array}$ & $-0.51^{* * *}$ \\
\hline & 1990-1999 & $\begin{array}{l}-0.02 \\
(0.009)\end{array}$ & $\begin{array}{c}0.09 \\
(0.03)\end{array}$ & $\begin{array}{l}-0.05 \\
(0.01)\end{array}$ & $0.14^{* * *}$ \\
\hline & 2000-2009 & $\begin{array}{l}0.67 \\
(0.009)\end{array}$ & $\begin{array}{c}0.55 \\
(0.03)\end{array}$ & $\begin{array}{c}0.70 \\
(0.01)\end{array}$ & $-0.14^{* * *}$ \\
\hline & 2010-2015 & $\begin{array}{c}0.54 \\
(0.01)\end{array}$ & $\begin{array}{c}0.28 \\
(0.04)\end{array}$ & $\begin{array}{c}0.61 \\
(0.01)\end{array}$ & $-0.33^{* * *}$ \\
\hline
\end{tabular}

Note: Columns (1) to (3) contain means and standard errors (in parentheses). Column (4) contains differences in means between old and new settlements and their statistical significance with ${ }^{\dagger}=p<0.1,{ }^{*}=p<0.05$, ${ }^{* *}=p<0.01,{ }^{* * *}=p<0.001$. 


\section{Identification strategies}

We apply two complementary identification strategies. The first strategy is a (spatial) matching strategy (e.g., Becker et al. 2015): its advantage is that it does not require the definition of an ethnic border between the formerly German- and Czech-dominated settlements, and its identification assumption is that no unobserved cofounding factors affect the migration rates of the settlements in the analysis. The second strategy is an RD design (Dell 2010; Becker et al. 2015; Egger and Lassmann 2015; Oto-Peralías and Romero-Ávila 2017). This provides a larger set of observations than in the matching procedure and relies on the weaker identification assumption that all unobserved confounding variables affecting migration decisions vary smoothly at the ethnic border. It, however, requires the definition of an ethnic border between the formerly German- and Czech-dominated settlements.

\subsection{Matching strategy}

The matching estimates apply on nearest neighbor matching (with replacement) based on a Euclidean distance measure ${ }^{14}$ using population in 1930 and geographic distance as matching variables. Population in 1930 is included as a pretreatment variable to control for important unobservable man-made amenities of agglomerations (e.g., provision of public services, infrastructure, hospitals, cinemas, or sports stadiums and others) that may affect migration. Distance, by contrast, is used to mitigate the effect of unobserved settlement characteristics such as the distance to regional capital, economic conditions, natural and man-made amenities, which also influence migration decisions.

We conduct three versions of the matching procedure. These differ in the maximum distance and population differences allowed for. In a first Version these maxima are 5 kilometers and 500 inhabitants. In a second Version they are 10 kilometers and 250 inhabitants. In the third and least restrictive Version they are 10 kilometers and 500 inhabitants. Depending on these restrictions the matching procedure provides between 46 and 179 matched pairs (Figure 3).

For each matching Version we estimate the following specification by ordinary least squares:

$$
y_{i t}=\phi_{p}+\gamma \mathrm{NS}_{i}+\beta \mathbf{Z}_{i}+\phi_{t}+\eta_{i t}
$$

14. The standardized Euclidean distance $d$ between two settlements is calculated as $d_{\mathrm{AB}}=\sqrt{g_{A B}^{2}+p_{A B}^{2}}$, where $g$ is the geographical distance between settlements adjusted for the earth's curvature, and $p$ is the population difference. Both $g$ and $p$ are normalized variables with zero mean and unit variance across all settlement pairs eligible for matching. A new settlement is matched with an old settlement that minimizes $d$. 
where $y_{i t}$ is one of the three outcome variables (emigration, immigration, and net immigration rates) defined for settlement $i$ in year $t, \phi_{p}$ is a match-specific intercept, $\mathrm{NS}_{i}$ is an indicator variable for a new settlement, and $\mathbf{Z}_{i}$ includes geographical variables (log of altitude, the terrain roughness, and the log of shortest distance to the Czech border). The year fixed effects $\phi_{t}$ are included to control for changes in institutions and economic developments affecting all settlements alike, and $\eta_{i t}$ is the error term. To study the development of the effects of resettlement over time we estimate Equation (2), which includes the interactions of $\mathrm{NS}_{i}$ with year fixed effects $\phi_{t}$ as follows:

$$
y_{i t}=\phi_{p}+\gamma_{t} \mathrm{NS}_{i}+\beta \mathbf{Z}_{i}+\phi_{t}+\eta_{i t}
$$

To assess the match quality, we present a series of balance tests for pretreatment and time-invariant exogenous variables in Table 2. The results suggest matched settlements are well-balanced in terms of geographical variables and population in 1930. New settlements, however, are located closer to the Czech border than old settlements, with this difference being statistically significant but small in absolute terms (between 1.3 to 2.7 kilometers). This finding was expected because of the geography of the Sudetenland. Nonetheless, we include distance to the Czech border in the model to control for the following: settlements closer to the border may be generally less attractive places to live. ${ }^{15}$

15. Further, we address this issue in our falsification tests in Section 5.3. 
Figure 3: Matched pairs of settlements by maximum permitted geographical distance and population differences (First part)

(a) Version 1

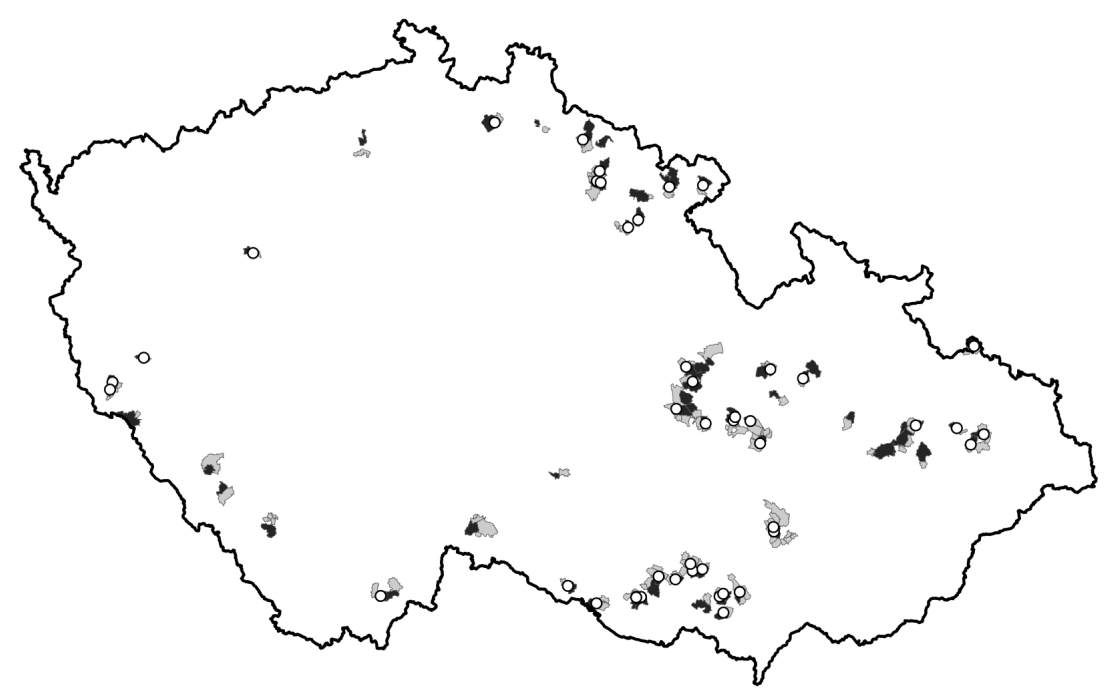

(b) Version 2

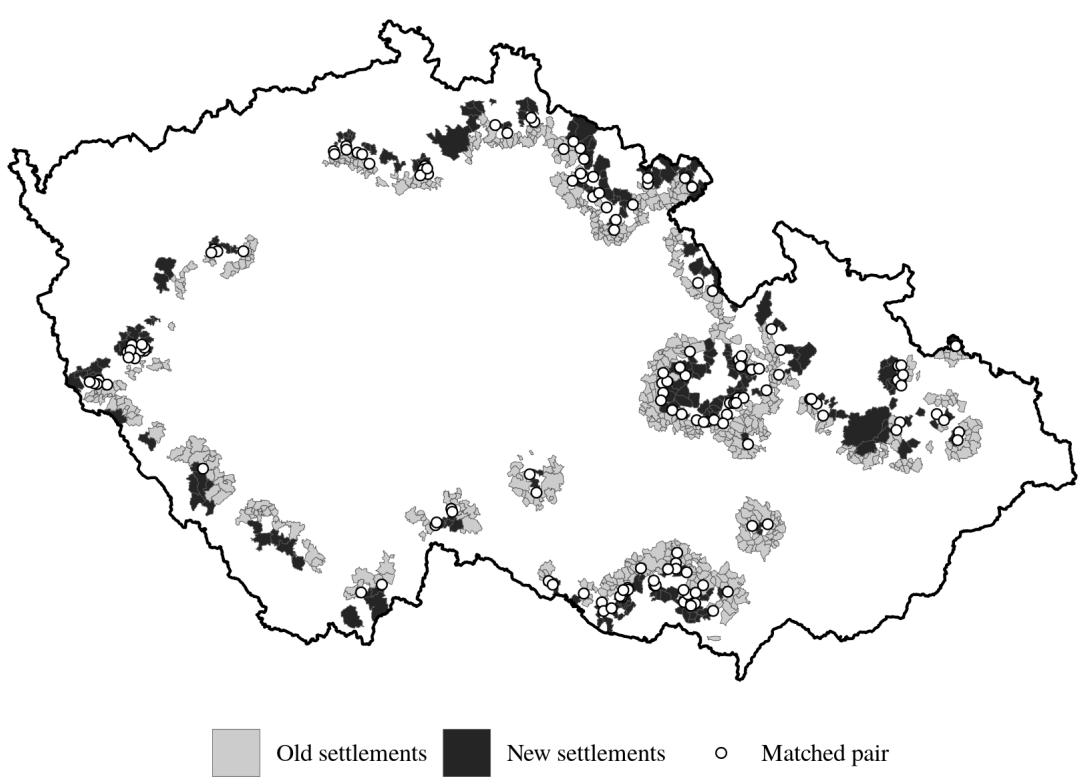


Figure 3: Matched pairs of settlements by maximum permitted geographical distance and population differences (Continued)

(c) Version 3

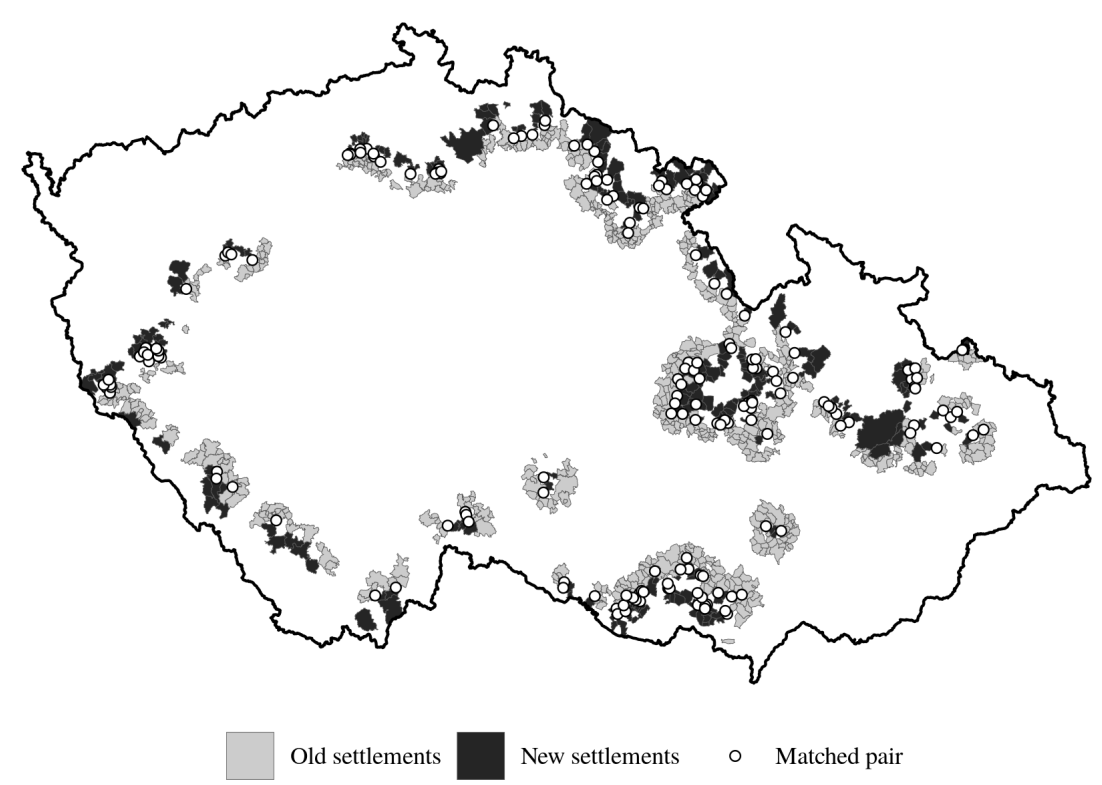

Source: CZSO, own calculations.

Note: In Version 1 settlements are matched only if they are located less than $5 \mathrm{~km}$ from each other and their population difference is less than 500 inhabitants. In Versions 2 and 3 these maxima are $10 \mathrm{~km}$ and 250 inhabitants, and $10 \mathrm{~km}$ and 500 inhabitants, respectively. 
Table 2: Balance tests for matched pairs

\begin{tabular}{|c|c|c|c|c|c|c|}
\hline & \multicolumn{6}{|c|}{ Matching version } \\
\hline & \multicolumn{2}{|c|}{ Version 1} & \multicolumn{2}{|c|}{ Version 2} & \multicolumn{2}{|c|}{ Version 3} \\
\hline & $\begin{array}{c}\text { Old } \\
\text { settlements }\end{array}$ & $\begin{array}{c}\text { New } \\
\text { settlements }\end{array}$ & $\begin{array}{c}\text { Old } \\
\text { settlements }\end{array}$ & $\begin{array}{c}\text { New } \\
\text { settlements }\end{array}$ & $\begin{array}{c}\text { Old } \\
\text { settlements }\end{array}$ & $\begin{array}{c}\text { New } \\
\text { settlements }\end{array}$ \\
\hline & (1) & (2) & (3) & (4) & (5) & (6) \\
\hline Altitude (meters) & $\begin{array}{l}348.304 \\
(19.691)\end{array}$ & $\begin{array}{l}353.598 \\
(18.840)\end{array}$ & $\begin{array}{l}362.827 \\
(10.604)\end{array}$ & $\begin{array}{l}385.405^{*} \\
(10.904)\end{array}$ & $\begin{array}{l}376.866 \\
(10.107)\end{array}$ & $\begin{array}{l}395.824 \\
(10.159)\end{array}$ \\
\hline Terrain roughness & $\begin{array}{c}2.699 \\
(0.188)\end{array}$ & $\begin{array}{c}2.574 \\
(0.203)\end{array}$ & $\begin{array}{c}2.679 \\
(0.112)\end{array}$ & $\begin{array}{c}2.800 \\
(0.112)\end{array}$ & $\begin{array}{c}2.798 \\
(0.099)\end{array}$ & $\begin{array}{c}2.910 \\
(0.102)\end{array}$ \\
\hline Distance to the country border $(\mathrm{km})$ & $\begin{array}{l}27.280 \\
(2.332)\end{array}$ & $\begin{array}{l}25.901^{* *} \\
(2.256)\end{array}$ & $\begin{array}{l}27.692 \\
(1.270)\end{array}$ & $\begin{array}{l}24.968^{* * *} \\
(1.202)\end{array}$ & $\begin{array}{l}26.622 \\
(1.168)\end{array}$ & $\begin{array}{l}24.005^{* * *} \\
(1.097)\end{array}$ \\
\hline Population $^{\mathrm{a}}$ & $\begin{array}{c}832.718 \\
(9.914)\end{array}$ & $\begin{array}{l}831.254 \\
(12.011)\end{array}$ & $\begin{array}{c}821.441 \\
(7.527)\end{array}$ & $\begin{array}{r}819.232 \\
(7.809)\end{array}$ & $\begin{array}{r}882.305 \\
(7.746)\end{array}$ & $\begin{array}{r}921.772 \\
(8.351)\end{array}$ \\
\hline Maximum geographical distance (meters) & \multicolumn{2}{|c|}{5000} & \multicolumn{2}{|c|}{10000} & \multicolumn{2}{|c|}{10000} \\
\hline Maximum difference in population & \multicolumn{2}{|c|}{500} & \multicolumn{2}{|c|}{250} & \multicolumn{2}{|c|}{500} \\
\hline Mean geographical distance (meters) & \multicolumn{2}{|c|}{4135.2} & \multicolumn{2}{|c|}{8112.6} & \multicolumn{2}{|c|}{7909.4} \\
\hline Mean difference in population & \multicolumn{2}{|c|}{206.4} & \multicolumn{2}{|c|}{118.6} & \multicolumn{2}{|c|}{214.6} \\
\hline Number of matched pairs & \multicolumn{2}{|c|}{46} & \multicolumn{2}{|c|}{147} & \multicolumn{2}{|c|}{179} \\
\hline
\end{tabular}

Note: In Version 1 settlements are matched only if they are located less than $5 \mathrm{~km}$ from each other and their population difference is less than 500 inhabitants. In Versions 2 and 3 these maxima are $10 \mathrm{~km}$ and 250 inhabitants, and $10 \mathrm{~km}$ and 500 inhabitants, respectively. Table 2 reports means (and White-Huber standard errors in parentheses) with statistical significance of differences in means between old and new settlements with ${ }^{\dagger}=p<0.1,{ }^{*}=p<0.05,{ }^{* *}=p<0.01,{ }^{* * *}=p<0.001$. For geographical variables tests for differences in means control for matched pair fixed effects. Tests for difference in population additionally control for the log of altitude, terrain roughness, and $\log$ of distance to the country border. P-values are calculated using White-Huber standard errors. 


\subsection{Regression discontinuity design and the definition of the ethnic border}

The RD design relies on a weaker identification assumption because it allows all unobserved variables affecting residential migration to vary smoothly at the cutoff defined by the ethnic border (e.g., Lee and Lemieux 2010). It also provides a larger number of observations on which the inference can be based. We estimate the following specification:

$$
y_{i t}=\gamma \mathrm{NS}_{i}+f\left(d_{i}\right)+\beta \mathbf{Z}_{i t}+\phi_{r}+\phi_{t}+\phi_{s}+\xi_{i t}
$$

where all symbols have the same interpretation as in Equation (1), $f\left(d_{i}\right)$ is an RD polynomial of the distance $\left(d_{i}\right)$ of the respective settlement from the ethnic border, $\phi_{r}$ are region fixed effects that control for any region-specific features of the outcome variable (or equivalently for the border segment) ${ }^{16}$ and $\phi_{s}$ are population fixed effects (decile as of 1930).

To analyze the dynamics of the causal effect we introduce interactions with year fixed effects as follows:

$$
y_{i t}=\gamma_{t} \mathrm{NS}_{i}+f\left(d_{i}\right) \lambda_{t}+\beta \mathbf{Z}_{i t}+\phi_{r}+\phi_{t}+\phi_{s}+\xi_{i t}
$$

such that the year fixed effect $\phi_{t}$ is interacted with the dummy for new settlements $\left(\mathrm{NS}_{i}\right)$ and with the RD polynomial $f\left(d_{i}\right)$ to account for possible changes in unobservables over time.

To define the ethnic border, we treat all settlements with a minority (less than 50\%) of ethnic Germans in 1930 as Czech settlements and all settlements with a majority of ethnic Germans in 1930 as German settlements. ${ }^{17}$ The ethnic border is then located at the border of German settlements contingent to a Czech settlement. ${ }^{18}$ This delineation yields a compact Czech territory in the center of today's Czech Republic surrounded by what once were German settlements in the south, west, and north of the country and a few former German enclaves surrounded by Czech settlements and Czech enclaves surrounded by former German settlements. From these, we removed two enclaves (one new and one old settlement, respectively) that were smaller than 10 square kilometers to ensure that we could define a border region sufficiently wide for an RD regression.

16. The Czech Republic is administratively divided into 14 regions ("kraj"). We checked that the borders of regions do not coincide with the ethnic border (Figure A.2 in the Appendix).

17. For the construction of the ethnic border we use the administrative areas of settlements from a series of maps (ArcČR 500 Version 3.3) developed by ARCDATA PRAHA, which are used for all geospatial visualization (https://www.arcdata.cz/produkty/geograficka-data/arccr-500).

18. Alternatively, the Munich Agreement border could be used instead of an ethnic border. In Figure A.3 in the Appendix, we map differences between two definitions of a border line. Since expulsion affected all ethnic Germans irrespective of whether they lived in the part of the country that was part of the German Reich or not, our definition of ethnic border provides an exact identification of the effects of resettlement. 
The distance of settlements to the ethnic border is defined by the distance of their reference points to the ethnic border. The estimation sample in the RD approach includes all new and old settlements located within 15 kilometers of the ethnic border to ensure symmetry in the number of observations at certain distances on both sides of the ethnic border (Figure 4). Figure 5 shows discontinuity plots for the geographic variables and the share of the German-speaking population in 1930 living on each side of the ethnic border for the estimation sample. There are no visible discontinuities in altitude, terrain roughness, distance to the Czech border, and population in 1930, but there is a sizeable discontinuity in the share of Germans at the cutoff. 
Figure 4: The ethnic border between Czech- and German-dominated settlements and settlements within a 15-km band around the border

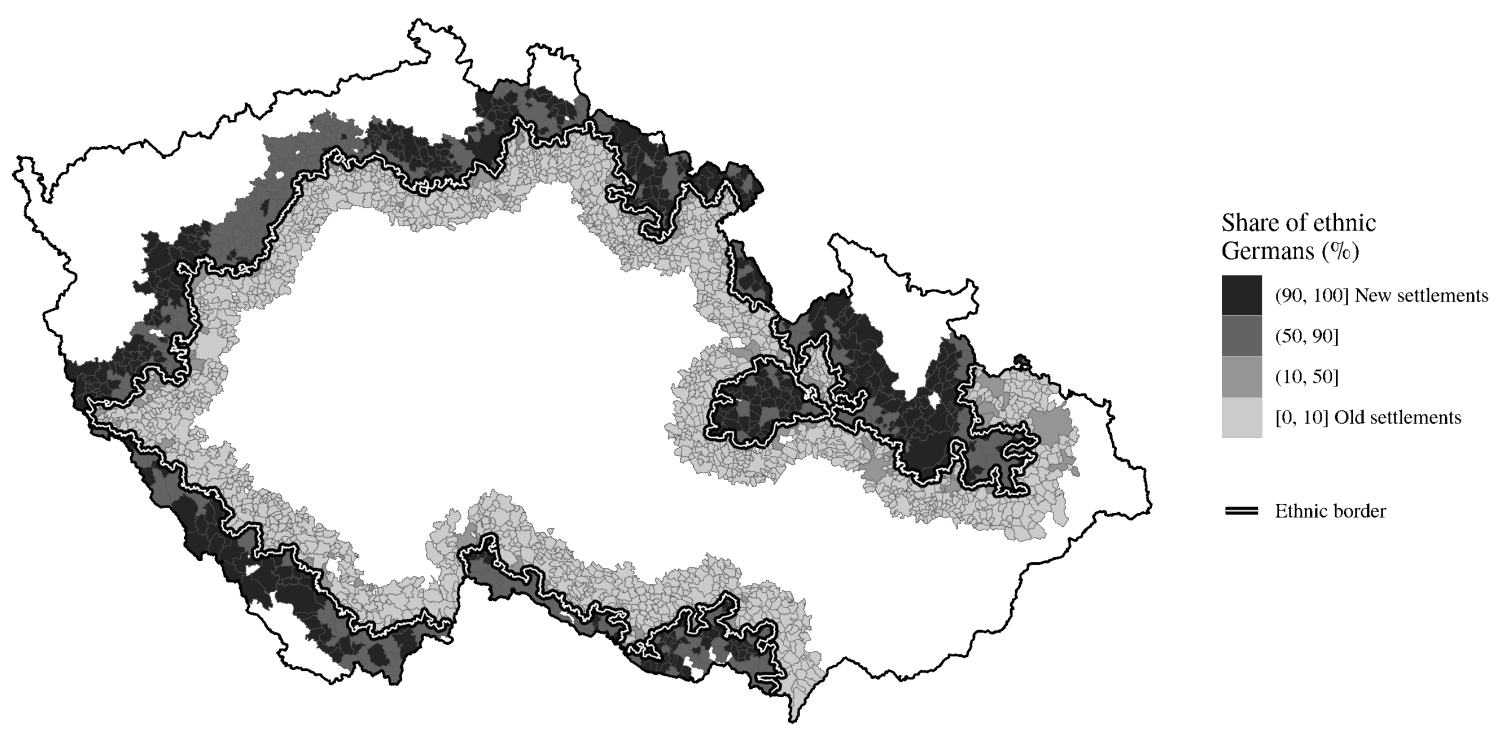

Source: CZSO, own calculations. 
Figure 5: Discontinuity plots of geographic variables, population, and share of ethnic Germans

(a) Share of ethnic Germans in 1930

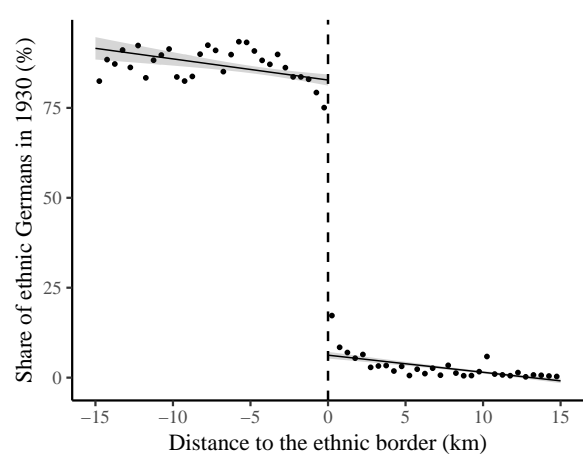

(c) Terrain roughness

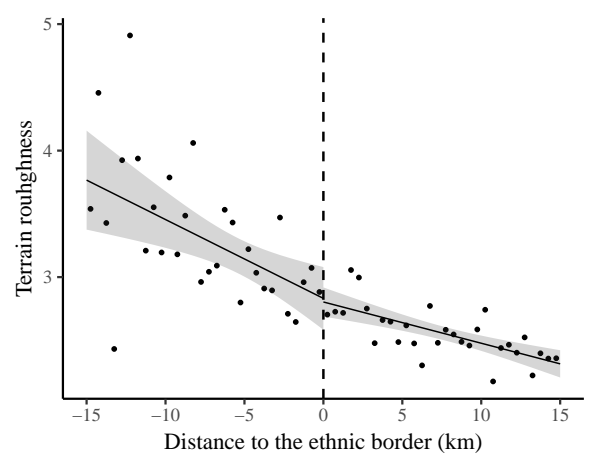

(b) Altitude

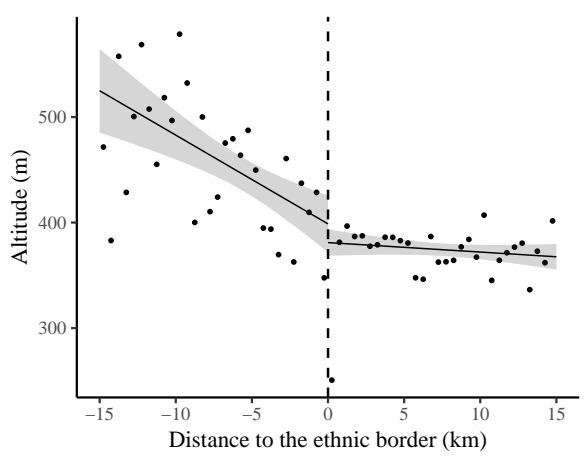

(d) Distance to the country border

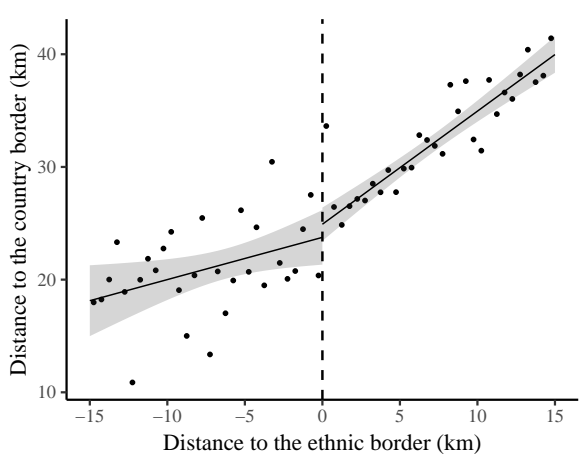

(e) Population in 1930

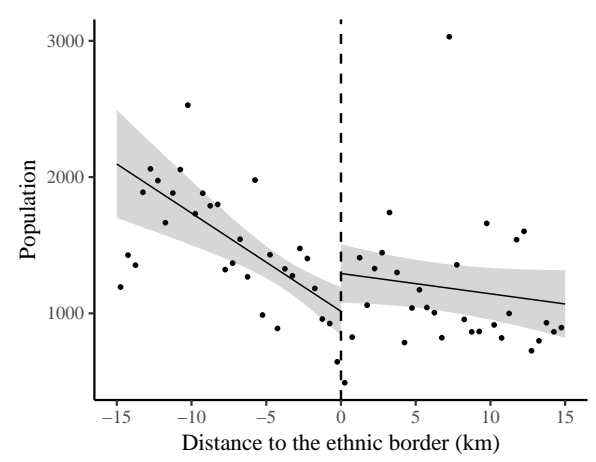

Source: CZSO, SRTM, own calculations.

Note: New settlements have negative distances to the ethnic border, and old settlements have a positive one. Settlements are aggregated to bins of $0.5 \mathrm{~km}$ represented by points. The smoothing lines are parametric linear predictions and shaded areas represent $95 \%$ confidence intervals. 


\section{Results}

\subsection{Baseline results}

Table 3 presents the baseline estimates of the parameter of interest $(\gamma)$ of Equation (1) from three versions of matching (in Columns (1) to (3)) and estimates of Equation (3) with three different RD polynomials (in Columns (4) to (6)).

These estimates suggest that, irrespective of the identification strategy used, resettlement increased emigration rates from the treated settlements by 0.6 to 0.7 percentage points and immigration rates by approximately 0.4 to 0.5 percentage points on average in the years 1971 to 2015 . Both these effects are statistically significant at the $5 \%$ level in all estimations. In addition, according to the results net immigration decreased by 0.1 to 0.3 percentage points per year on average in the studied period. These effects are also statistically significant in all versions of the estimate except for the RD estimation with a third-order RD polynomial.

\subsection{Effects over time}

Baseline estimates apply to the average of the years 1971 to 2015. In this period, today's Czech Republic underwent several notable political and institutional changes, such as the fall of the communist regime, subsequent transition from a planned to a market economy, dissolution of Czechoslovakia, and accession to the European Union. Also in that period, the original settlers in the resettled areas went through almost their entire life cycle as an individual born at the beginning of resettlement in 1945 would have been 70 years old in 2015. To study the dynamics of the effect of resettlement we estimate Equation (2) with the least restrictive matching specification (Version 3) because it provides the largest number of observations and Equation (4) using a linear RD polynomial because it minimizes the Bayesian Information Criterion (BIC).

Estimates of the year-treatment interaction terms are plotted in Figures 6 and 7. The effects are once more highly consistent across two identification strategies and indicate a particularly pronounced increase in emigration and immigration rates in the treatment settlements in the 1970s and mid-1980s. In the 1970s, emigration rates were as much as 2 percentage points and immigration rates as much as 1.5 percentage points higher in the new settlements (relative to a baseline emigration rate in the old settlements of $3.2 \%$ and an immigration rate to the old settlements of $2.1 \%$ ). The overall effect on net migration in this period was negative, that is, new settlements' population decreased because of emigration. This decrease may be due to the return of (potentially disappointed) original settlers or their grown descendants. By the mid-1980s the gap in net immigration rates, however, narrowed 
Table 3: Impact of the resettlement on migration rates

\begin{tabular}{|c|c|c|c|c|c|c|}
\hline & \multicolumn{6}{|c|}{ Identification strategy } \\
\hline & \multicolumn{3}{|c|}{ Matching strategy } & \multicolumn{3}{|c|}{ RD strategy } \\
\hline & \multicolumn{3}{|c|}{ Matching version } & \multicolumn{3}{|c|}{ RD polynomial } \\
\hline & Version 1 & Version 2 & Version 3 & $1^{\text {st }}$ order & $2^{\text {nd }}$ order & $3^{\text {rd }}$ order \\
\hline & (1) & (2) & (3) & (4) & (5) & (6) \\
\hline & \multicolumn{6}{|c|}{$\begin{array}{l}\text { Dependent variable: } \\
\text { Emigration rate }(\%)\end{array}$} \\
\hline New settlement $(=1)$ & $\begin{array}{l}0.583^{* * *} \\
(0.083)\end{array}$ & $\begin{array}{l}0.702^{* * *} \\
(0.050)\end{array}$ & $\begin{array}{l}0.746^{* * *} \\
(0.041)\end{array}$ & $\begin{array}{l}0.740^{* * *} \\
(0.063)\end{array}$ & $\begin{array}{l}0.697^{* * *} \\
(0.093)\end{array}$ & $\begin{array}{l}0.579^{* * *} \\
(0.134)\end{array}$ \\
\hline Adjusted $\mathrm{R}^{2}$ & 0.176 & 0.217 & 0.217 & 0.168 & 0.168 & 0.168 \\
\hline Observations & 3,342 & 10,404 & 12,788 & 82,423 & 82,423 & 82,423 \\
\hline & \multicolumn{6}{|c|}{$\begin{array}{l}\text { Dependent variable: } \\
\text { Immigration rate }(\%)\end{array}$} \\
\hline New settlement $(=1)$ & $\begin{array}{l}0.467^{* * *} \\
(0.076)\end{array}$ & $\begin{array}{l}0.534^{* * *} \\
(0.055)\end{array}$ & $\begin{array}{l}0.463^{* * *} \\
(0.062)\end{array}$ & $\begin{array}{l}0.517^{* * *} \\
(0.070)\end{array}$ & $\begin{array}{l}0.458^{* * *} \\
(0.103)\end{array}$ & $\begin{array}{l}0.379^{*} \\
(0.149)\end{array}$ \\
\hline Adjusted $\mathrm{R}^{2}$ & 0.118 & 0.125 & 0.134 & 0.089 & 0.089 & 0.089 \\
\hline \multirow[t]{2}{*}{ Observations } & 3,342 & 10,404 & 12,788 & 82,423 & 82,423 & 82,423 \\
\hline & \multicolumn{6}{|c|}{$\begin{array}{c}\text { Dependent variable: } \\
\text { Net immigration rate }(\%)\end{array}$} \\
\hline New settlement $(=1)$ & $\begin{array}{c}-0.117^{* *} \\
(0.045)\end{array}$ & $\begin{array}{l}-0.168^{* * *} \\
(0.049)\end{array}$ & $\begin{array}{l}-0.283^{* * *} \\
(0.058)\end{array}$ & $\begin{array}{l}-0.224^{* * *} \\
(0.063)\end{array}$ & $\begin{array}{c}-0.240^{* *} \\
(0.093)\end{array}$ & $\begin{array}{l}-0.199 \\
(0.132)\end{array}$ \\
\hline Adjusted $\mathrm{R}^{2}$ & 0.119 & 0.136 & 0.139 & 0.095 & 0.095 & 0.095 \\
\hline Observations & 3,342 & 10,404 & 12,788 & 82,423 & 82,423 & 82,423 \\
\hline
\end{tabular}

Note: Estimates from Equations (1) and (3) in the main text. Matching estimates: In Version 1 settlements are matched only if they are located less than $5 \mathrm{~km}$ from each other and their population difference is less than 500 inhabitants. In Versions 2 and 3 these maxima are $10 \mathrm{~km}$ and 250 inhabitants, and $10 \mathrm{~km}$ and 500 inhabitants, respectively. All estimates control for pair fixed effects, year fixed effects, log of altitude, terrain roughness, and log of the distance to the country border. RD strategy: Only settlements within a $15 \mathrm{~km}$ band around the ethnic border are considered. Results control for year fixed effects, an RD polynomial, and region fixed effects, population fixed effect, log of altitude, terrain roughness, and log of the distance to the country border. Symbols represent statistical significance of differences in means between old and new settlements with ${ }^{\dagger}=p<0.1,{ }^{*}=p<0.05,{ }^{* *}=p<0.01,{ }^{* * *}=p<0.001$. Values in brackets are clustered standard errors. 
and stabilized at a level comparable to those of the old settlements for the remainder of the observation period.

Emigration rates from the new settlements, however, were statistically significantly higher than in old settlements in all years except for 2013. Furthermore, these differences declined during the 1970s to the mid-1980s but then remained at approximately 0.4 percentage points higher in the new than the old settlements for the rest of the observation period. Similar observations apply to immigration rates, although these differences are not statistically significant in all years.

This stability of the estimates for the effects on immigration and emigration from the mid-1980s to 2015 implies that the effect was affected neither by the many political and institutional changes experienced by the Czech Republic in that time period nor by the rapidly changing macroeconomic environment. There are no visible changes in the causal impact at the time of fall of the Iron Curtain and the start of economic transition (1989), dissolution of Czechoslovakia (1993), and the accession to the European Union (2004). Similarly, the estimates are very stable throughout the deep (so-called transition) recession at the beginning of the 1990s, the Czech currency crisis in 1997 and the following recession, the economic crisis in the late 2000s, and the great depression of 2009.

\subsection{Falsification tests and robustness}

One concern regarding these findings is that-as aforementioned-the new settlements are located closer to the German border. This could threaten the interpretation of our results because the causal effects of resettlement if settlements closer to the border of the country are in general less attractive for living. This may be of particular relevance in the context of communist Czechoslovakia before 1989 because in those times, due to heavy policing of the border, borders to "Western countries" were particularly unattractive places to live. We therefore conduct two falsification tests to address this concern where we counter-factually shift the ethnic border of the Sudetenland 5 kilometers away from, respectively, 5 kilometers toward the border of the Czech Republic. These placebo treatments (Table 4) indicate no statistically significant differences between settlements at the counterfactual ethnic border for emigration and net immigration rates irrespective of where the border is shifted. For immigration rates, however, statistically significant effects (at the 5\% level) are found only when the ethnic border is shifted toward the border of the Czech Republic and when using second- or third- order polynomials for estimation.

Six additional robustness tests are conducted: we (1) use the 1950 population as a matching and control variable, (2) conduct the RD analysis and define treated settlements as settlements with a share of ethnic Germans of $50 \%$ or more and all others as a control group, (3) check that the results are not due to historical institutional differences arising 
Figure 6: Impact of the resettlement on migration rates by year (Matching strategy)

(a) Emigration rate

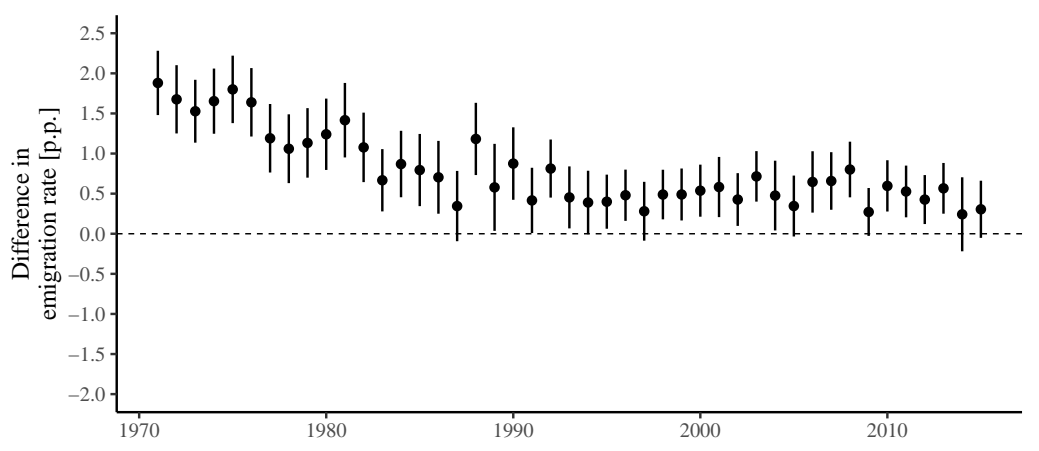

(b) Immigration rate

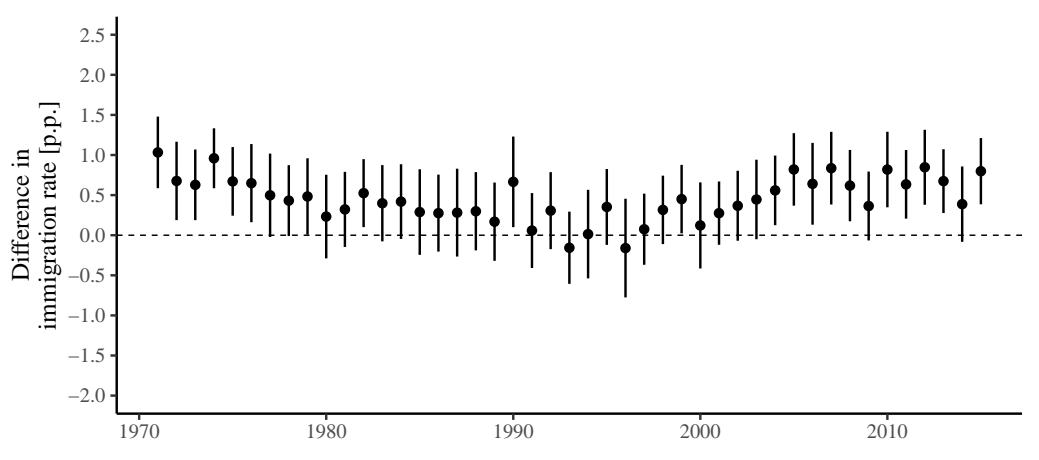

(c) Net immigration rate

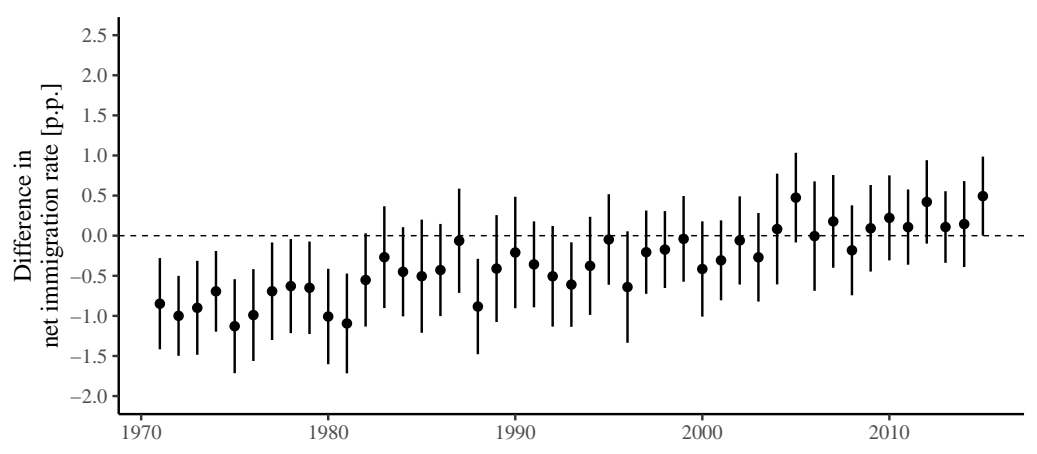

Note: Figure reports estimates of the impact of the resettlement on the migration rates from Equation (2). Settlements are matched allowing for maximum geographical distance of $10 \mathrm{~km}$ and difference in population of 500 persons (Version 3). All estimates control for pair fixed effects, year fixed effects, log of altitude, terrain roughness, and $\log$ of the distance to the country border. Points represent the point estimates and the associated bars the $95 \%$ confidence intervals of the estimates. Standard errors are clustered by settlement. 
Figure 7: Impact of the resettlement on migration rates by year (RD strategy)

(a) Emigration rate

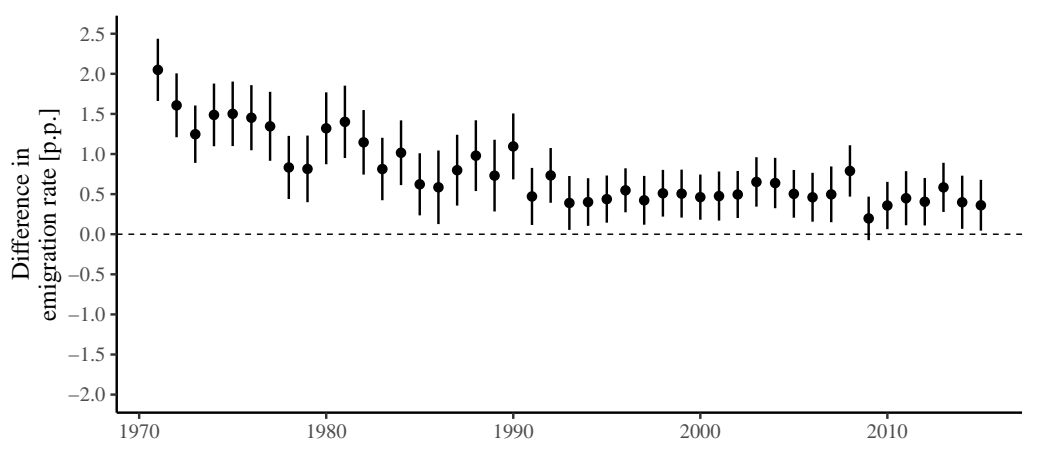

(b) Immigration rate

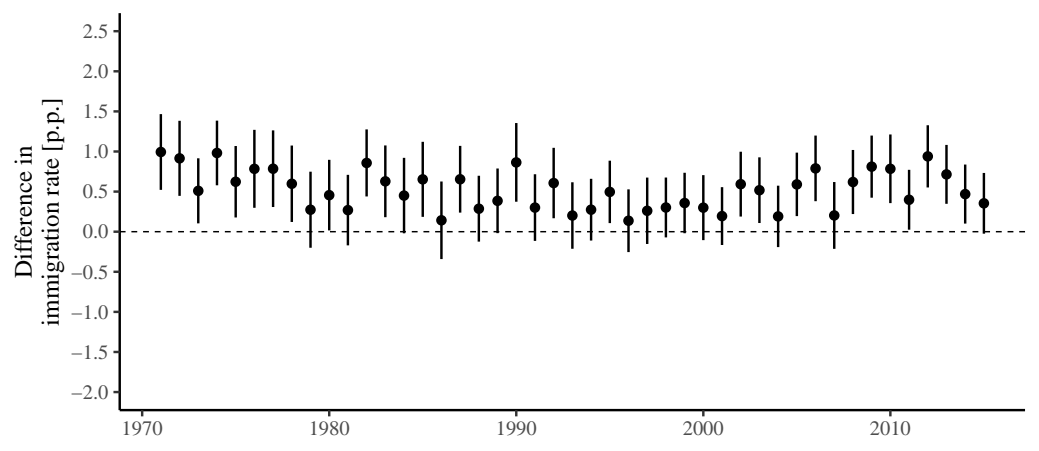

(c) Net immigration rate

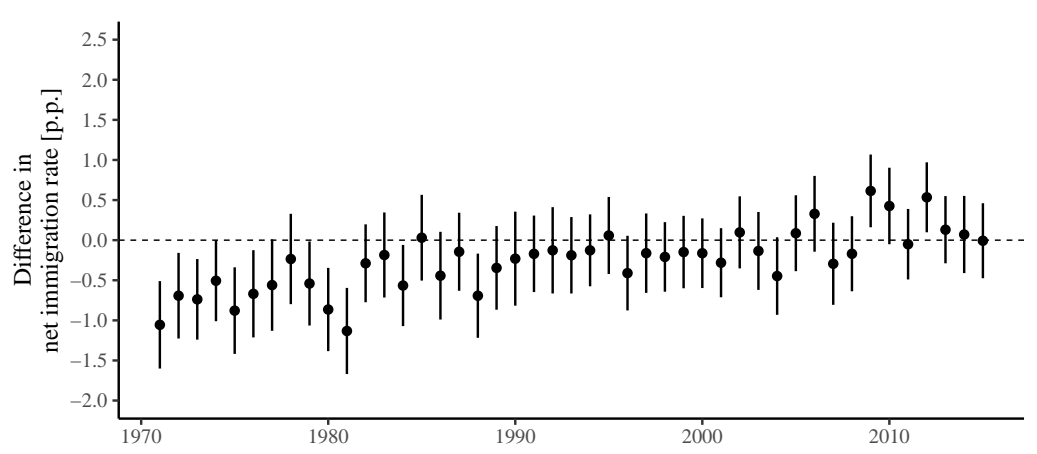

Note: Figure reports estimates of the impact of the resettlement on the migration rates from Equation (4). Only settlements within a $15 \mathrm{~km}$ band around the ethnic border are considered. Results control for the interaction of the year fixed effects with the dummy variable for new settlement, interaction of year fixed effect with a first-order polynomial forcing function, and region fixed effects, year fixed effects, population fixed effect, $\log$ of altitude, terrain roughness, and $\log$ of the distance to the country border. Points represent the point estimates and the associated bars the $95 \%$ confidence intervals of the estimates. Standard errors are clustered by settlement. 
Table 4: Placebo tests

\begin{tabular}{|c|c|c|c|c|c|c|}
\hline & \multicolumn{6}{|c|}{ Placebo test } \\
\hline & \multirow{2}{*}{\multicolumn{3}{|c|}{$\begin{array}{c}\text { Placebo test on the sample } \\
\text { of new settlements } \\
\text { (shift of the ethnic border } \\
\text { by } 5 \mathrm{~km} \text { towards the country border) } \\
\text { Polynomial forcing function }\end{array}$}} & \multirow{2}{*}{\multicolumn{3}{|c|}{$\begin{array}{c}\begin{array}{c}\text { Placebo test on the sample } \\
\text { of old settlements } \\
\text { (shift of the ethnic border }\end{array} \\
\text { by } 5 \mathrm{~km} \text { outwards the country border) } \\
\text { Polynomial forcing function }\end{array}$}} \\
\hline & & & & & & \\
\hline & $1^{\text {st }}$ order & $2^{\text {nd }}$ order & $3^{\text {rd }}$ order & $1^{\text {st }}$ order & $2^{\text {nd }}$ order & $3^{\text {rd }}$ order \\
\hline & (1) & (2) & (3) & (4) & (5) & (6) \\
\hline & \multicolumn{6}{|c|}{$\begin{array}{l}\text { Dependent variable: } \\
\text { Emigration rate }(\%)\end{array}$} \\
\hline Placebo new settlement $(=1)$ & $\begin{array}{c}0.046 \\
(0.133)\end{array}$ & $\begin{array}{c}0.303 \\
(0.203)\end{array}$ & $\begin{array}{c}0.351 \\
(0.273)\end{array}$ & $\begin{array}{c}0.005 \\
(0.049)\end{array}$ & $\begin{array}{c}0.025 \\
(0.076)\end{array}$ & $\begin{array}{c}0.003 \\
(0.104)\end{array}$ \\
\hline Adjusted $\mathrm{R}^{2}$ & 0.226 & 0.227 & 0.228 & 0.110 & 0.110 & 0.111 \\
\hline \multirow[t]{2}{*}{ Observations } & 15,070 & 15,070 & 15,070 & 67,353 & 67,353 & 67,353 \\
\hline & \multicolumn{6}{|c|}{$\begin{array}{l}\text { Dependent variable: } \\
\text { Immigration rate }(\%)\end{array}$} \\
\hline Placebo new settlement $(=1)$ & $\begin{array}{c}0.136 \\
(0.138)\end{array}$ & $\begin{array}{l}0.414^{*} \\
(0.195)\end{array}$ & $\begin{array}{r}0.533^{*} \\
(0.264)\end{array}$ & $\begin{array}{c}0.015 \\
(0.080)\end{array}$ & $\begin{array}{c}0.003 \\
(0.123)\end{array}$ & $\begin{array}{l}-0.021 \\
(0.172)\end{array}$ \\
\hline Adjusted $\mathrm{R}^{2}$ & 0.070 & 0.070 & 0.070 & 0.078 & 0.078 & 0.078 \\
\hline \multirow[t]{2}{*}{ Observations } & 15,070 & 15,070 & 15,070 & 67,353 & 67,353 & 67,353 \\
\hline & \multicolumn{6}{|c|}{$\begin{array}{c}\text { Dependent variable: } \\
\text { Net immigration rate }(\%)\end{array}$} \\
\hline Placebo new settlement $(=1)$ & $\begin{array}{c}0.090 \\
(0.120)\end{array}$ & $\begin{array}{c}0.111 \\
(0.178)\end{array}$ & $\begin{array}{c}0.182 \\
(0.226)\end{array}$ & $\begin{array}{c}0.010 \\
(0.077)\end{array}$ & $\begin{array}{c}-0.021 \\
(0.118)\end{array}$ & $\begin{array}{c}-0.023 \\
(0.168)\end{array}$ \\
\hline Adjusted $\mathrm{R}^{2}$ & 0.124 & 0.124 & 0.124 & 0.090 & 0.090 & 0.090 \\
\hline Observations & 15,070 & 15,070 & 15,070 & 67,353 & 67,353 & 67,353 \\
\hline
\end{tabular}

Note: Estimates based on (3) in the main text. Only settlements within a $15 \mathrm{~km}$ band around the ethnic border are considered. Results control for year fixed effects, an RD polynomial, and region fixed effects, population fixed effect, log of altitude, terrain roughness, and $\log$ of the distance to the country border. Symbols represent statistical significance of differences in means between old and new settlements with $\dagger=p<0.1,{ }^{*}=p<0.05,{ }^{* *}=p<0.01,{ }^{* * *}=p<0.001$. Values in brackets are clustered standard errors. 
from the times when the Sudetenland belonged to German Reich (i.e., from 1938 to 1945) by focusing only on matches where both old and new settlements were located in the German Reich, (4) exclude the settlements located in the northeast of the Czech Republic characterized by a large number of ethnic border irregularities, (5) use a balanced panel dataset, and (6) include outliers omitted in the previous analysis. ${ }^{19}$

Table 5 reports the results of these robustness tests for the least restrictive matching specification (Version 3) and the RD estimates using a linear RD polynomial. The estimates are highly robust and comparable to our baseline results. Throughout the estimated coefficients for the emigration rate the range is between 0.7 and 0.9 percentage points, and those for the immigration rate are between 0.5 and 0.7 percentage points. The changes in results are thus mostly smaller than 0.1 percentage points relative to our baseline estimates. The estimates for the net immigration rate are less robust. This is statistically significant at the 5\% level only, when excluding the part of Sudetenland located in the northeast of the Czech Republic and when including outliers.

In summary, this evidence is consistent with a strong medium-term causal negative impact of resettlement on net immigration on new settlements, which could be associated with return or onward migration of the original settlers (or their children). More important, this evidence suggests a long-lasting effect of resettlement on immigration and emigration rates and thus the population churn. This implies a persistently lower attachment of people in new settlements that continued to persist even 70 years after the beginning of resettlement.

19. A detailed description for these robustness tests is in the Appendix C, which also reports results for other versions of the matching and RD estimates. 
Table 5: Robustness tests

\begin{tabular}{|c|c|c|c|c|c|c|c|}
\hline & & \multicolumn{6}{|c|}{ Identification strategy } \\
\hline & & \multicolumn{3}{|c|}{ Matching strategy } & \multicolumn{3}{|c|}{ RD strategy } \\
\hline & & \multicolumn{3}{|c|}{ Dependent variable: } & \multicolumn{3}{|c|}{ Dependent variable: } \\
\hline & & $\begin{array}{l}\text { Emigration } \\
\text { rate }(\%)\end{array}$ & $\begin{array}{l}\text { Immigration } \\
\text { rate }(\%)\end{array}$ & $\begin{array}{c}\text { Net } \\
\text { immigration } \\
\text { rate }(\%)\end{array}$ & $\begin{array}{l}\text { Emigration } \\
\text { rate }(\%)\end{array}$ & $\begin{array}{l}\text { Immigration } \\
\text { rate }(\%)\end{array}$ & $\begin{array}{c}\text { Net } \\
\text { immigration } \\
\text { rate }(\%)\end{array}$ \\
\hline & & (1) & $(2)$ & (3) & (4) & (5) & (6) \\
\hline (1) & The 1950 population as a matching and control variable & $\begin{array}{l}0.758^{* * *} \\
(0.052)\end{array}$ & $\begin{array}{l}0.509^{* * *} \\
(0.047)\end{array}$ & $\begin{array}{c}-0.249^{* * * *} \\
(0.044)\end{array}$ & $\begin{array}{l}0.712^{* * *} \\
(0.062)\end{array}$ & $\begin{array}{l}0.549^{* * *} \\
(0.071)\end{array}$ & $\begin{array}{c}-0.163^{* *} \\
(0.062)\end{array}$ \\
\hline (2) & The RD analysis with an alternative definition of treated and control settlements & & & & $\begin{array}{l}0.653^{* * *} \\
(0.043)\end{array}$ & $\begin{array}{l}0.435^{* * *} \\
(0.049)\end{array}$ & $\begin{array}{l}-0.218^{* * *} \\
(0.044)\end{array}$ \\
\hline (3) & Check on the impact of institutional differences & $\begin{array}{l}0.915^{* * *} \\
(0.065)\end{array}$ & $\begin{array}{l}0.529^{* * *} \\
(0.084)\end{array}$ & $\begin{array}{l}-0.386^{* * *} \\
(0.070)\end{array}$ & & & \\
\hline (4) & $\begin{array}{l}\text { Exclusion of a part of ethnic border characterized by a large number } \\
\text { of ethnic border irregularities from the RD analysis }\end{array}$ & & & & $\begin{array}{l}0.744^{* * *} \\
(0.081)\end{array}$ & $\begin{array}{l}0.547^{* * *} \\
(0.093)\end{array}$ & $\begin{array}{r}-0.197^{*} \\
(0.080)\end{array}$ \\
\hline (5) & Using balanced panel & $\begin{array}{l}0.785^{* * *} \\
(0.055)\end{array}$ & $\begin{array}{l}0.471^{* * *} \\
(0.096)\end{array}$ & $\begin{array}{l}-0.314^{* * *} \\
(0.090)\end{array}$ & $\begin{array}{l}0.828^{* * *} \\
(0.078)\end{array}$ & $\begin{array}{l}0.478^{* * *} \\
(0.080)\end{array}$ & $\begin{array}{c}-0.350^{* * *} \\
(0.068)\end{array}$ \\
\hline (6) & Including outliers & $\begin{array}{l}0.838^{* * *} \\
(0.061)\end{array}$ & $\begin{array}{l}0.585^{* * *} \\
(0.085)\end{array}$ & $\begin{array}{c}-0.252^{* * *} \\
(0.068)\end{array}$ & $\begin{array}{l}0.884^{* * *} \\
(0.083)\end{array}$ & $\begin{array}{l}0.717^{* * *} \\
(0.100)\end{array}$ & $\begin{array}{c}-0.167^{*} \\
(0.084)\end{array}$ \\
\hline
\end{tabular}

Note: Table reports estimates from Equations (1) and (3) in the main text. Matching estimates are based on Version 3 of the matching and control for pair fixed effects, year fixed effects, log of altitude, terrain roughness, and log of the distance to the country border. RD strategy considers only settlements within a $15 \mathrm{~km}$ band around the ethnic border. Results control for year fixed effects, a linear RD polynomial, and region fixed effects, population fixed effect, log of altitude, terrain roughness, and log of the distance to the country border. Symbols represent statistical significance of differences in means between old and new settlements with ${ }^{\dagger}=p<0.1{ }^{*}=p<0.05$, ${ }^{* *}=p<0.01,{ }^{* * *}=p<0.001$. Values in brackets are clustered standard errors. 


\section{Mechanisms}

One potential explanation for this long-term impact of resettlement on residential migration is a persistent reduction in social capital in treated settlements. This explanation accords with many of the descriptions of these settlements by historians (Vaněk 1996; Glassheim 2006; Matějka 2008; Čapka et al. 2005; Spurný 2011) and is consistent with theoretical models of the impact of social capital on migration decisions (e.g., David et al. 2010; Bräuninger and Tolciu 2011). These show that if social capital yields utility and can be only partially transferred across settlements, individuals may choose to forego a financially profitable move of residence to derive utility from social capital. With endogenous social capital investments such models generate two stable equilibria. The first has low social capital and high mobility, and the second has high social capital and low mobility (Bräuninger and Tolciu 2011). Thus, in terms of these models, the destruction of social capital in new settlements could have moved these settlements to a low social capital and high mobility equilibrium.

An alternative explanation could be based on the self-selection of settlers to new settlements: Because it is highly likely that the Sudetenland was resettled by the more mobile groups among the Czech population at the time, it could be that either migration-related values were transferred across generations among the population of the resettled settlements or that the resettled settlements are still populated by more mobile population groups to this day.

To assess the plausibility of these alternative explanations we examine further data sets that are informative regarding the impact of differences in the age and education structure of the population between the old and new settlements as well as differences in values, election turnout, and other social capital measures between the new and old settlements.

\subsection{Controlling for differences in population structure}

In a first exercise we are interested in whether differences between the new and old settlements in the post-resettlement education and age structure have any impact on the estimated causal effects of resettlement. To this end, we use data from the post-WWII censuses and re-estimate matching and $\mathrm{RD}$ estimates on data restricted to the years immediately after these censuses; in these, we control for the share of tertiary- and compulsory-educated residents and the share of population in age brackets between 20-29, 30-39, 40-49, 50-59, and 60-69 years old. According to the results (in Table 6), the estimated effects on emigration and immigration rates decrease only slightly.

Taken together, the matching and RD estimates indicate that differences in emigration rates between the new and old settlements when statistically significant are at approximately 
Table 6: Impact of the resettlement on migration rates controlling for population changes

\begin{tabular}{|c|c|c|c|c|c|c|}
\hline & \multicolumn{6}{|c|}{ Identification strategy } \\
\hline & \multicolumn{3}{|c|}{ Matching strategy } & \multicolumn{3}{|c|}{ RD strategy } \\
\hline & \multicolumn{3}{|c|}{ Matching version } & \multicolumn{3}{|c|}{ RD polynomial } \\
\hline & Version 1 & Version 2 & Version 3 & $1^{\text {st }}$ order & $2^{\text {nd }}$ order & $3^{\text {rd }}$ order \\
\hline & (1) & (2) & (3) & (4) & (5) & (6) \\
\hline & \multicolumn{6}{|c|}{$\begin{array}{l}\text { Dependent variable: } \\
\text { Emigration rate }(\%)\end{array}$} \\
\hline New settlement $(=1)$ & $\begin{array}{c}0.247 \\
(0.181)\end{array}$ & $\begin{array}{l}0.601^{* * *} \\
(0.123)\end{array}$ & $\begin{array}{l}0.611^{* * *} \\
(0.110)\end{array}$ & $\begin{array}{l}0.604^{* * *} \\
(0.099)\end{array}$ & $\begin{array}{l}0.547^{* * *} \\
(0.149)\end{array}$ & $\begin{array}{l}0.570^{* *} \\
(0.213)\end{array}$ \\
\hline Adjusted R2 & 0.077 & 0.167 & 0.167 & 0.132 & 0.132 & 0.132 \\
\hline \multirow[t]{2}{*}{ Observations } & 312 & 970 & 1,190 & 7,577 & 7,577 & 7,577 \\
\hline & \multicolumn{6}{|c|}{$\begin{array}{l}\text { Dependent variable: } \\
\text { Immigration rate }(\%)\end{array}$} \\
\hline New settlement $(=1)$ & $\begin{array}{c}0.306 \\
(0.257)\end{array}$ & $\begin{array}{l}0.592^{* * *} \\
(0.155)\end{array}$ & $\begin{array}{l}0.588^{* * *} \\
(0.146)\end{array}$ & $\begin{array}{l}0.726^{* * *} \\
(0.118)\end{array}$ & $\begin{array}{l}0.642^{* * *} \\
(0.173)\end{array}$ & $\begin{array}{r}0.585^{*} \\
(0.243)\end{array}$ \\
\hline Adjusted R2 & 0.081 & 0.098 & 0.103 & 0.086 & 0.086 & 0.086 \\
\hline \multirow[t]{2}{*}{ Observations } & 312 & 970 & 1,190 & 7,577 & 7,577 & 7,577 \\
\hline & \multicolumn{6}{|c|}{$\begin{array}{c}\text { Dependent variable: } \\
\text { Net immigration rate }(\%)\end{array}$} \\
\hline New settlement $(=1)$ & $\begin{array}{c}0.059 \\
(0.245)\end{array}$ & $\begin{array}{l}-0.009 \\
(0.203)\end{array}$ & $\begin{array}{l}-0.023 \\
(0.184)\end{array}$ & $\begin{array}{c}0.122 \\
(0.137)\end{array}$ & $\begin{array}{c}0.095 \\
(0.197)\end{array}$ & $\begin{array}{c}0.015 \\
(0.277)\end{array}$ \\
\hline Adjusted R2 & 0.113 & 0.083 & 0.097 & 0.073 & 0.073 & 0.073 \\
\hline Observations & 312 & 970 & 1,190 & 7,577 & 7,577 & 7,577 \\
\hline
\end{tabular}

Note: Table reports estimates from Equations (1) and (3) in the main text. Matching estimates: In Version 1 settlements are matched only if they are located less than $5 \mathrm{~km}$ from each other and their population difference is less than 500 inhabitants. In Versions 2 and 3 these maxima are $10 \mathrm{~km}$ and 250 inhabitants, and $10 \mathrm{~km}$ and 500 inhabitants, respectively. All estimates control for pair fixed effects, year fixed effects, $\log$ of altitude, terrain roughness, and log of the distance to the country border as well as the age and education structure of the population. RD strategy: Only settlements within a $15 \mathrm{~km}$ band around the ethnic border are considered. Results control for year fixed effects, a RD polynomial, and region fixed effects, population fixed effect, log of altitude, terrain roughness, and log of the distance to the country border as well as the age and education structure of the population. Symbols represent statistical significance of differences in means between old and new settlements with ${ }^{\dagger}=p<0.1,{ }^{*}=p<0.05,{ }^{* *}=p<0.01,{ }^{* * *}=p<0.001$. Values in brackets are clustered standard errors. 
0.6 percentage points (compared with 0.6 to 0.7 percentage points in the baseline results), and immigration rates differ by 0.6 to 0.7 percentage points (and are thus comparable with the benchmark estimate of 0.5 percentage points). The only outliers are the results of the Version of matching where settlements are allowed to be located at most 5 kilometers from each other and to have had a maximum difference in population of 500 inhabitants; in these, the estimated effects are approximately 0.2 percentage points but statistically insignificant because of the few observations available in this comparison.

In addition, in both identification strategies, the results for net immigration rates are now statistically insignificant. This finding provides further support for the higher net immigration rates in the new settlements (i.e., mainly in the period up to the 1980s) being primarily due to the impact of the resettlement on the population structure of the resettled territories (i.e., associated with the aging of the settlers), and for the higher population churn and the lower attachment to the place of residence being largely independent of the impact of resettlement on the population structure.

\subsection{Values}

Regarding social values, we examine data from a survey on the values of the old (aged 60-74 years) and young (aged 18-29 years) generation in the Czech Republic (Český venkov 2004: život mladých a starých lidi””). We run a linear regression on the responses to the value-related questions in this survey on a dummy variable that takes the value of one if the respondent resided in a new settlement and zero if the respondent resided in an old settlement.

In these regressions we control for gender, age, previous migration, education, labor market status, marital status, household size and settlement size, and county fixed effects. ${ }^{20}$ The results (Table 7) suggest no statistically significant differences in the values between the new and old settlements among the old or young residents. This finding applies to all values except the importance attributed to hobbies by old inhabitants; however, this could just as well be caused by a type II error.

20. Due to the smaller number of settlements covered in this survey neither the matching nor the regression discontinuity design approach is feasible. 
Table 7: Differences in values between new and old settlements

\begin{tabular}{|c|c|c|c|c|c|c|c|c|c|c|}
\hline & \multicolumn{10}{|c|}{ Things and values very important in personal life $(=1)$} \\
\hline & $\begin{array}{c}\text { Nature, } \\
\text { environment }\end{array}$ & $\begin{array}{c}\text { Job, } \\
\text { occupation }\end{array}$ & Relationships & $\begin{array}{c}\text { Faith, } \\
\text { spiritual values }\end{array}$ & Hobbies & Housing & Friendship & Health & $\begin{array}{l}\text { Family life } \\
\text { and children }\end{array}$ & $\begin{array}{c}\text { Material } \\
\text { conditions }\end{array}$ \\
\hline & (1) & (2) & (3) & (4) & (5) & (6) & (7) & (8) & (9) & (10) \\
\hline & \multicolumn{10}{|c|}{ Regression results } \\
\hline New settlement $(=1)$ & $\begin{array}{c}0.049 \\
(0.075)\end{array}$ & $\begin{array}{c}0.113 \\
(0.080)\end{array}$ & $\begin{array}{c}-0.032 \\
(0.084)\end{array}$ & $\begin{array}{c}-0.029 \\
(0.046)\end{array}$ & $\begin{array}{c}0.076 \\
(0.077)\end{array}$ & $\begin{array}{c}0.042 \\
(0.075)\end{array}$ & $\begin{array}{c}0.072 \\
(0.066)\end{array}$ & $\begin{array}{c}-0.046 \\
(0.090)\end{array}$ & $\begin{array}{c}-0.062 \\
(0.087)\end{array}$ & $\begin{array}{c}0.004 \\
(0.088)\end{array}$ \\
\hline Adjusted $\mathrm{R}^{2}$ & 0.039 & 0.050 & 0.043 & 0.039 & 0.021 & 0.018 & 0.037 & 0.044 & 0.226 & 0.016 \\
\hline \multirow[t]{2}{*}{ Observations } & 680 & 680 & 680 & 680 & 680 & 680 & 680 & 679 & 680 & 679 \\
\hline & \multicolumn{10}{|c|}{ Panel B: Old cohort (60-74) } \\
\hline New settlement $(=1)$ & $\begin{array}{c}-0.019 \\
(0.087)\end{array}$ & $\begin{array}{l}0.030 \\
(0.096)\end{array}$ & $\begin{array}{c}-0.045 \\
(0.094)\end{array}$ & $\begin{array}{c}-0.015 \\
(0.080)\end{array}$ & $\begin{array}{l}0.231^{* * *} \\
(0.086)\end{array}$ & $\begin{array}{c}0.006 \\
(0.081)\end{array}$ & $\begin{array}{c}0.004 \\
(0.092)\end{array}$ & $\begin{array}{c}-0.078^{\dagger} \\
(0.045)\end{array}$ & $\begin{array}{c}-0.076 \\
(0.084)\end{array}$ & $\begin{array}{c}0.108 \\
(0.103)\end{array}$ \\
\hline Adjusted $\mathrm{R}^{2}$ & 0.026 & -0.011 & 0.022 & 0.084 & 0.006 & 0.022 & 0.010 & 0.043 & 0.109 & 0.036 \\
\hline \multirow[t]{3}{*}{ Observations } & 611 & 602 & 609 & 608 & 610 & 611 & 609 & 610 & 610 & 610 \\
\hline & \multicolumn{10}{|c|}{ Descriptive statistics } \\
\hline & \multicolumn{10}{|c|}{ Panel C: Young cohort (18-29) } \\
\hline Old settlements & $\begin{array}{c}0.579 \\
(0.020)\end{array}$ & $\begin{array}{c}0.661 \\
(0.019)\end{array}$ & $\begin{array}{c}0.441 \\
(0.020)\end{array}$ & $\begin{array}{c}0.073 \\
(0.011)\end{array}$ & $\begin{array}{c}0.253 \\
(0.018)\end{array}$ & $\begin{array}{c}0.659 \\
(0.019)\end{array}$ & $\begin{array}{c}0.511 \\
(0.020)\end{array}$ & $\begin{array}{c}0.822 \\
(0.016)\end{array}$ & $\begin{array}{c}0.657 \\
(0.019)\end{array}$ & $\begin{array}{c}0.394 \\
(0.020)\end{array}$ \\
\hline \multirow[t]{3}{*}{ New settlements } & 0.591 & 0.750 & 0.443 & 0.057 & 0.250 & 0.727 & 0.534 & 0.747 & 0.602 & 0.398 \\
\hline & $(0.053)$ & $(0.046)$ & $(0.053)$ & $(0.025)$ & $(0.046)$ & $(0.048)$ & $(0.054)$ & $(0.047)$ & $(0.053)$ & $(0.053)$ \\
\hline & \multicolumn{10}{|c|}{ Panel D: Old cohort (60-74) } \\
\hline Old settlements & $\begin{array}{c}0.680 \\
(0.019)\end{array}$ & $\begin{array}{c}0.304 \\
(0.019)\end{array}$ & $\begin{array}{c}0.564 \\
(0.020)\end{array}$ & $\begin{array}{c}0.256 \\
(0.018)\end{array}$ & $\begin{array}{c}0.218 \\
(0.017)\end{array}$ & $\begin{array}{c}0.568 \\
(0.020)\end{array}$ & $\begin{array}{c}0.543 \\
(0.020)\end{array}$ & $\begin{array}{c}0.930 \\
(0.010)\end{array}$ & $\begin{array}{c}0.762 \\
(0.017)\end{array}$ & $\begin{array}{c}0.270 \\
(0.018)\end{array}$ \\
\hline New settlements & $\begin{array}{c}0.674 \\
(0.050)\end{array}$ & $\begin{array}{c}0.287 \\
(0.050)\end{array}$ & $\begin{array}{c}0.506 \\
(0.053)\end{array}$ & $\begin{array}{l}0.227 \\
(0.045)\end{array}$ & $\begin{array}{c}0.295 \\
(0.049)\end{array}$ & $\begin{array}{c}0.607 \\
(0.052)\end{array}$ & $\begin{array}{c}0.568 \\
(0.053)\end{array}$ & $\begin{array}{c}0.932 \\
(0.027)\end{array}$ & $\begin{array}{c}0.670 \\
(0.050)\end{array}$ & $\begin{array}{c}0.386 \\
(0.052)\end{array}$ \\
\hline
\end{tabular}

Table reports estimated coefficients on an indicator variable for new settlements after controlling for settlement (log of altitude, terrain roughness, log of distance to the country border, region fixed effect, and population fixed effect) and personal (age group, education, labor market status, marital status, household size, and for being born in the settlement of residence) characteristics. Standard errors clustered by settlement are reported in parentheses with: ${ }^{\dagger}=p<0.1,{ }^{* *}=p<0.05,{ }^{* * *}=p<0.01$, ${ }^{* * *}=p<0.001$. Descriptive statistics are the mean and the standard deviations (in parentheses). 


\subsection{Election turnout}

Further, we apply the same matching and RD design analyses as aforementioned using voter turnout data in municipal elections at the settlement level as a dependent variable because this variable has often been used as an indicator of overall social capital in the literature (e.g., Knack 1992; Hotchkiss and Rupasingha 2018) ${ }^{21}$. According to the results (Table 8), voter turnout in municipal elections was statistically significantly lower in the new compared with the old settlements. In the RD design this impact ranges on average from 3.0 to 3.5 percentage points. According to the matching estimates, the differences amount to 2.0 to 3.5 percentage points; however, the differences are statistically significant only in cases where the data provides a sufficient number of observations (i.e., in cases where we allow matched settlements to be at most 10 kilometers from each other).

Further, the results of year by year matching and RD design estimates for election turnout (Figure 8) suggest that these differences between the new and old settlements have reduced continuously since the times of the fall of the Iron Curtain and attained a similar value in both types of settlements in the 2010 and 2014 elections. Thus, resettlement also led to a reduced voter turnout in municipal elections, that was, however, not as long lived as the impact on the population churn.

21. In municipal elections citizens are not allowed to vote outside their constituency. This rules out potential bias caused by, e.g., correspondence voting. 
Table 8: Impact of the resettlement on migration rates on election turnout in municipal elections

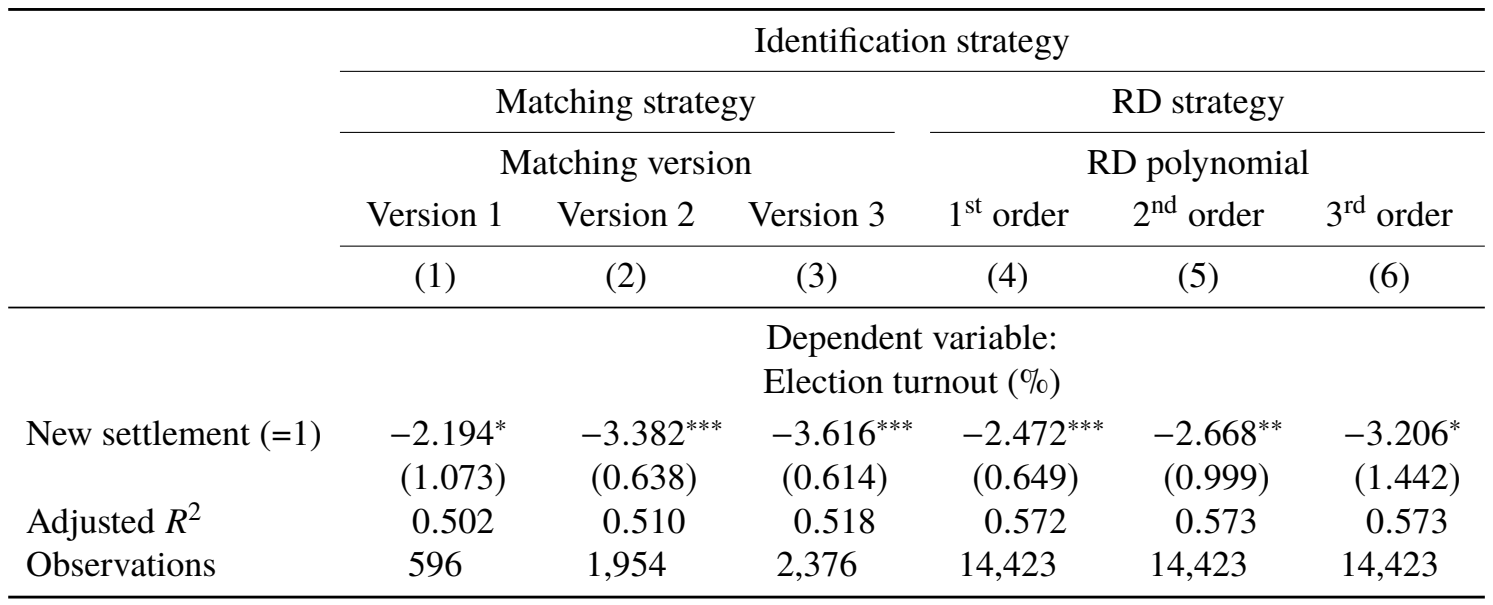

Note: All regressions are based on municipal elections from the period 1990-2014. Matching estimates: In Version 1 settlements are matched only if they are located less than $5 \mathrm{~km}$ from each other and their population difference is less than 500 inhabitants. In Versions 2 and 3 these maxima are $10 \mathrm{~km}$ and 250 inhabitants, and $10 \mathrm{~km}$ and 500 inhabitants, respectively. All estimates control for pair fixed effects, year fixed effects, log of altitude, terrain roughness, and log of the distance to the country border as well as the age and education structure of the population. RD strategy: Only settlements within a $15 \mathrm{~km}$ band around the ethnic border are considered. Results control for year fixed effects, an RD polynomial, and region fixed effects, population fixed effect, log of altitude, terrain roughness, and log of the distance to the country border as well as the age and education structure of the population. Symbols represent statistical significance of differences in means between old and new settlements with ${ }^{\dagger}=p<0.1,{ }^{*}=p<0.05,{ }^{* *}=p<0.01,{ }^{* * *}=p<0.001$. Values in brackets are clustered standard errors. 
Figure 8: Impact of the resettlement on electoral turnout in municipal elections by year

(a) Matching strategy

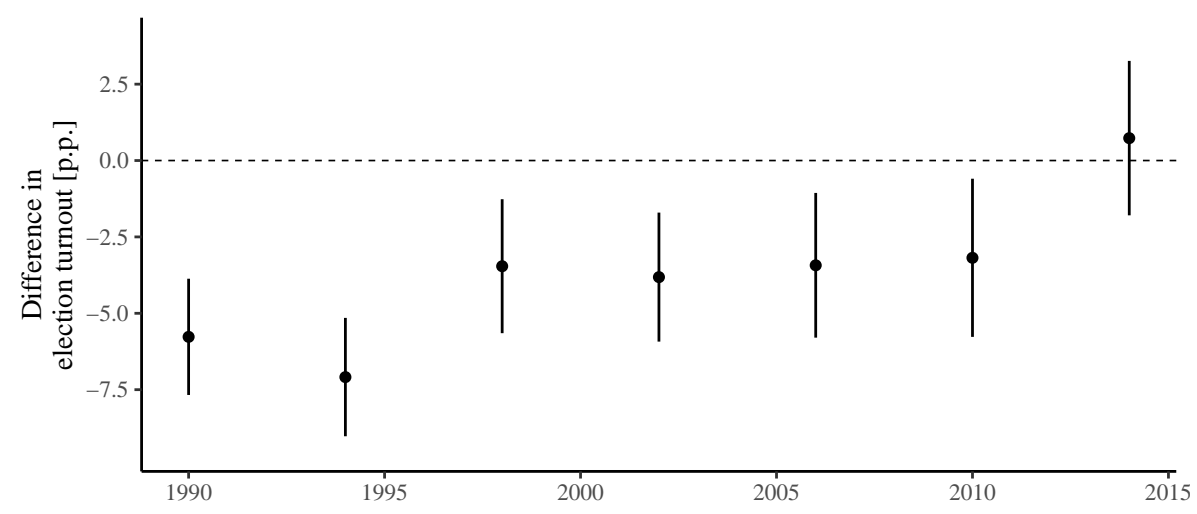

(b) RD strategy

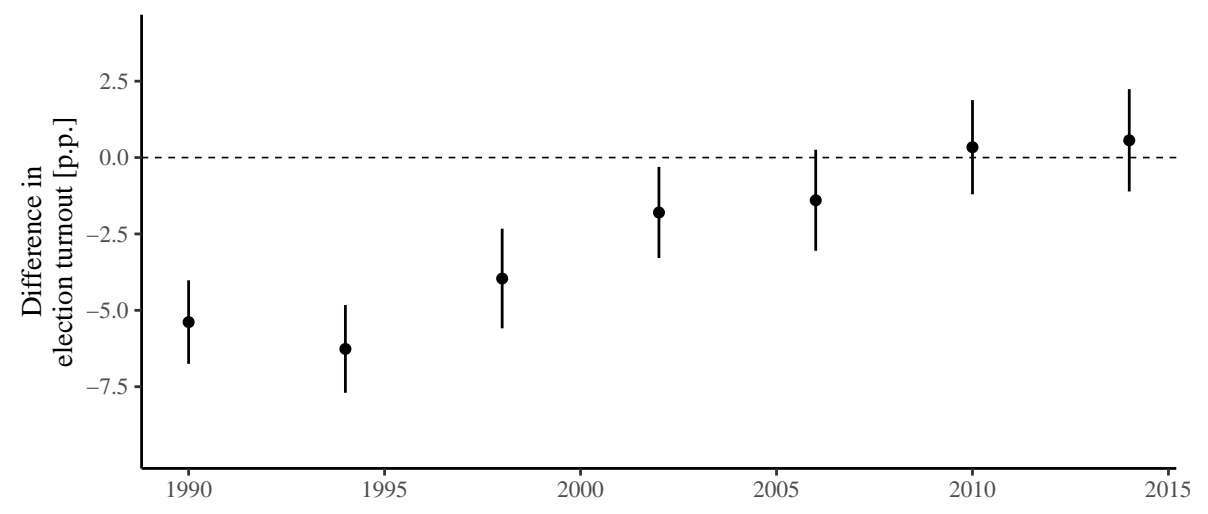

Note: Figure reports estimates of the impact of the resettlement on the electoral turnout in local elections from Equations (2) and (4). Matching estimates are based on Version three of our baseline estimates (i.e., they allow for a maximum geographical distance of $10 \mathrm{~km}$ and difference in population of 500 persons between settlements). All estimates control for pair fixed effects, year fixed effects, log of altitude, terrain roughness, and log of the distance to the country border. In the RD strategy settlements within a $15 \mathrm{~km}$ band around the ethnic border are considered. Results control for the interaction of the year fixed effects with the dummy variable for new settlement, interaction of year fixed effect with a first-order polynomial forcing function, and region fixed effects, year fixed effects, population fixed effect, log of altitude, terrain roughness, and $\log$ of the distance to the country border. Points represent the point estimates and the associated bars the $95 \%$ confidence intervals of the estimates. Standard errors are clustered by settlement. 


\subsection{Club membership, event participation, donations and voluntary work}

Finally, to assess differences in club membership, event participation, donations, and the propensity to participate in voluntary work we use data from the survey "Český venkov 2003 - situace pred vstupem do EU." We use the responses of mayors from the first wave of the survey to a question on the number of events organized by local clubs and green activities (i.e., collective activities to improve the environment and living conditions in the settlement) in their settlement. From the second wave of the survey we consider questions on whether individuals are a member of a club, participated in an event, have made a donation, or have committed to conducting voluntary work. Once more, we regress the responses at the settlement level to these questions on a dummy variable indicating that a particular settlement was a new settlement, and the same settlement-level controls are also used in the remainder of this analysis. For the individual-level data, we additionally control for gender, age, home-ownership status, education, marital status, household size, and labor market status. ${ }^{22}$

The results (Table 9) show statistically significant differences between the new and old settlements in variables associated with the participation in events organized by local clubs, green activities, and club membership in the settlements. These differences are also quantitatively important because they indicate that there are on average 2.8 fewer events organized by clubs and 0.9 fewer green events organized in the new compared with old settlements in 2003 and that the probability to participate in a club or civil society organization is 0.1 to 0.2 percentage points lower in the new compared with the old settlements. The same does not, however, apply to indicators less closely associated with local social capital such as the frequency with which people attend events, provide donations, and participate in voluntary work. Consistent with our hypothesis this implies lower social capital in old settlements in particular when it comes to social capital embedded in clubs and civil society organizations.

22. A regression discontinuity design or matching analysis is infeasible due to the low number of observations. 
Table 9: Differences in events organization, attendance, club membership and charitable activities between new and old settlements

\begin{tabular}{|c|c|c|c|c|c|c|}
\hline & \multicolumn{2}{|c|}{ Panel A: Wave 1} & \multicolumn{4}{|c|}{ Panel B: Wave 2} \\
\hline & $\begin{array}{l}\text { Events } \\
\text { organized by } \\
\text { local clubs (n) }\end{array}$ & $\begin{array}{c}\text { Green } \\
\text { activities } \\
\text { (n) }\end{array}$ & $\begin{array}{c}\text { Club } \\
\text { membership } \\
(=1)\end{array}$ & $\begin{array}{c}\text { Events } \\
\text { attendance } \\
(=1)\end{array}$ & $\begin{array}{l}\text { Donations } \\
\qquad(=1)\end{array}$ & $\begin{array}{c}\text { Voluntary } \\
\text { work } \\
(=1)\end{array}$ \\
\hline & (1) & (2) & (3) & (4) & (5) & (6) \\
\hline & \multicolumn{6}{|c|}{ Regression results } \\
\hline New settlement $(=1)$ & $\begin{array}{c}-2.909^{*} \\
(1.297)\end{array}$ & $\begin{array}{c}-0.882^{* * *} \\
(0.310)\end{array}$ & $\begin{array}{r}-0.150^{\dagger} \\
(0.082)\end{array}$ & $\begin{array}{c}0.003 \\
(0.062)\end{array}$ & $\begin{array}{r}-0.032 \\
(0.083)\end{array}$ & $\begin{array}{r}-0.030 \\
(0.066)\end{array}$ \\
\hline Adjusted $\mathrm{R}^{2}$ & 0.086 & 0.032 & 0.055 & 0.115 & 0.094 & 0.069 \\
\hline \multirow[t]{2}{*}{ Observations } & 1,181 & 1,181 & 1,525 & 1,525 & 1,523 & 1,523 \\
\hline & \multicolumn{6}{|c|}{ Descriptive statistics } \\
\hline Old settlements & $\begin{array}{c}10.598 \\
(0.462)\end{array}$ & $\begin{array}{c}2.233 \\
(0.093)\end{array}$ & $\begin{array}{c}0.428 \\
(0.013)\end{array}$ & $\begin{array}{c}0.596 \\
(0.013)\end{array}$ & $\begin{array}{c}0.586 \\
(0.013)\end{array}$ & $\begin{array}{c}0.248 \\
(0.012)\end{array}$ \\
\hline New settlements & $\begin{array}{c}8.535 \\
(0.802)\end{array}$ & $\begin{array}{c}1.208 \\
(0.177)\end{array}$ & $\begin{array}{c}0.314 \\
(0.035)\end{array}$ & $\begin{array}{c}0.599 \\
(0.037)\end{array}$ & $\begin{array}{c}0.465 \\
(0.038)\end{array}$ & $\begin{array}{c}0.256 \\
(0.033)\end{array}$ \\
\hline
\end{tabular}

Regression results report estimated coefficients on an indicator variable for new settlements. Regressions in panels $\mathrm{A}$ and $\mathrm{B}$ control for the log of altitude, terrain roughness, log of distance to the country border, population fixed effects, and region fixed effects. Settlement-level regressions in the Panel A also control for age structure (shares of 20-29, 30-39, 40-49, 50-59, and 60-69 in total population) and the shares of the low and high educated in population 15+ in 2001. Individual-level regressions in Panel B control for gender, age group, home-ownership status, education, marital status, household size, and labor market status. Values in parentheses are White-Huber standard errors in Panel A, and standard errors are clustered by settlement in Panel B: ${ }^{\dagger}=p<0.1,{ }^{* *}=p<0.05,{ }^{* * *}=p<0.01,{ }^{* * *}=p<0.001$. Descriptive statistics are the mean and the standard deviations (in parentheses) for new and old settlements. 


\section{Conclusions}

In this paper, we exploit the resettlement of the Sudetenland after WWII as a natural experiment to analyze the long-term impact of the destruction of the social structure of a community associated with this resettlement on residential migration. This large and unexpected resettlement involved the relocation of 2 million Czech inhabitants to settlements previously populated by ethnic Germans. Using two identification strategies, we find that resettlement increased emigration rates from the affected settlements by 0.6 to 0.7 percentage points per year (the average emigration rate is $3.8 \%$ ). Immigration rates increased by 0.4 to 0.5 percentage points, and net immigration rates decreased by 0.1 to 0.2 percentage points. These effects were larger at the beginning of the observation period both for emigration and immigration rates, and the statistically significant higher net immigration rates apply only until the mid-1980s. From the mid-1980s to the end of the observation period (2015), no further impact of resettlement on net immigration rates is observed. By contrast, emigration and immigration rates remained at stably and statistically significantly higher levels in the affected settlements. Both emigration and immigration rates in new settlements were still by 0.4 percentage points higher relative to the old settlements in 2015, without there being any indication of a decrease in these differences.

This indicates a much longer-lived impact of resettlement on the population churn than on net immigration rates and can be taken as evidence that even in 2015 the population in resettled settlements was still less attached to their place of residence. Furthermore, the higher population churn survived such important institutional changes as the fall of the communist regime, transition from a planned to a market economy, separation from the Slovak Republic, and accession to the European Union, which occurred in the Czech Republic in that period and are independent of macroeconomic developments in the Czech Republic in that time.

Examining the potential causal mechanisms for this long-run and stable impact of resettlement on the attachment of residents, we find that controlling for differences in population structure of resettled settlements does not reduce our estimated causal effects on emigration and immigration rates significantly. Similarly, inhabitants of resettled settlements share the same values as residents of settlements that were not resettled. They also do not differ in a statistically significant manner in terms of their inclination to give donations, attend social events, and participate in voluntary work but have fewer club memberships and less frequently organize social events. In addition, up until the early 2000s, resettled settlements had lower voter turnout rates in local elections than settlements not resettled. This finding leads us to conclude that lower social capital embedded in local 
clubs and civic organizations in new settlements has been a notable cause for the lower attachment of the population to the resettled settlements.

These findings corroborate previous empirical evidence on the long-term impact that the destruction of the social structures of a region has on its economic, social, and political development. In particular, the finding of higher population churn and lower civic participation in clubs and similar communal activities in the resettled settlements is consistent with a number of recent theoretical and empirical contributions on the role of social capital in shaping migration decisions. These show that if social capital yields utility and is endogenously invested in by the resident population two stable equilibria arise: one with low social capital and high migration and one with high social capital and low migration (Bräuninger and Tolciu 2011 or David et al. 2010). Based on an interpretation of our results from this perspective, the destruction of social capital in new settlements may have moved the resettled settlements to a low social capital and a high migration equilibrium while old settlements continued to be in high social capital and low migration equilibrium. 


\section{References}

Acemoglu, Daron, Tarek A Hassan, and James A Robinson. 2011. "Social structure and development: A legacy of the Holocaust in Russia." The Quarterly Journal of Economics 126 (2): 895-946.

Akbulut-Yuksel, Mevlude, and Mutlu Yuksel. 2015. "The long-term direct and external effects of Jewish Expulsions in Nazi Germany." American Economic Journal: Economic Policy 7 (3): 58-85.

Alexander, Manfred. 2008. Kleine Geschichte der böhmischen Länder. Reclam.

Becker, Sascha O, Katrin Boeckh, Christa Hainz, and Ludger Woessmann. 2015. "The empire is dead, long live the empire! Long-run persistence of trust and corruption in the bureaucracy." The Economic Journal 126 (590): 40-74.

Brakman, Steven, Harry Garretsen, and Marc Schramm. 2004. "The strategic bombing of German cities during World War II and its impact on city growth." Journal of Economic Geography 4 (2): 201-218.

Bräuninger, Michael, and Andreia Tolciu. 2011. "Should I stay or should I go? Regional mobility and social capital." Journal of Institutional and Theoretical Economics JITE 167 (3): 434-444.

Čapka, František, Lubomír Slezák, and Jaroslav Vaculík. 2005. Nové osídlení pohraničí českých zemí po druhé světové válce. Akademické nakladatelství CERM.

CZSO. 2014. Národní struktura obyvatel. Technical report. https://www.czso.cz/documents/ 10180/20551765/170223-14.pdf. Prague: Czech Statistical Office.

Daněk, Petr. 1995. "Towards cultural regionalisation of the Czech Lands: Sudeten half a century after the transfer." Scripta Fac. Brun 25:41-60.

David, Quentin, Alexandre Janiak, and Etienne Wasmer. 2010. "Local social capital and geographical mobility." Journal of Urban Economics 68 (2): 191-204.

Dell, Melissa. 2010. “The persistent effects of Peru's mining mita.” Econometrica 78 (6): 1863-1903.

Dvořák, Tomáš. 2013. Vnitřní odsun 1947-1953: Závěrečná fáze očisty pohraničí v politických a společenských souvislostech poválečného Československa. Brno: Matice Moravská. 
Egger, Peter H, and Andrea Lassmann. 2015. "The causal impact of common native language on international trade: Evidence from a spatial regression discontinuity design.” The Economic Journal 125 (584): 699-745.

Gerlach, David. 2010. "Beyond Expulsion: The Emergence of "Unwanted Elements" in the Postwar Czech Borderlands, 1945-1950." East European Politics and Societies 24 (2): 269-293.

. 2017. The Economy of Ethnic Cleansing: The Transformation of the German-Czech Borderlands after World War II. Cambridge University Press.

Glassheim, Eagle. 2000. "National mythologies and ethnic cleansing: The expulsion of Czechoslovak Germans in 1945." Central European History 33 (4): 463-486.

- 2006. "Ethnic cleansing, communism, and environmental devastation in Czechoslovakia's Borderlands, 1945-1989." The Journal of Modern History 78 (1): 65-92.

Grosfeld, Irena, Alexander Rodnyansky, and Ekaterina Zhuravskaya. 2013. "Persistent antimarket culture: a legacy of the pale of settlement after the holocaust." American Economic Journal: Economic Policy 5 (3): 189-226.

Hotchkiss, Julie L, and Anil Rupasingha. 2018. "Individual Social Captial and Migration.”

Knack, Stephen. 1992. "Civic norms, social sanctions, and voter turnout." Rationality and Society 4 (2): 133-156.

Lee, David S, and Thomas Lemieux. 2010. "Regression discontinuity designs in economics." Journal of economic literature 48 (2): 281-355.

Majerová, Věra, et al. 2003. Český venkov 2003, Situace před vstupem do EU. Prague: PEF CZU Praha.

—. 2004. Český venkov 2004, Život mladých a starých lidí. Prague: PEF CZU Praha. Matějka, Ondřej. 2008. Social Capital in Contemporary Sudetenland, edited by Joseph D Lewandowski and Milan Znoj, 277-293. Newcastle, UK: Cambridge Scholars.

Meixner, Rudolf. 1988. Geschichte der Sudetendeutschen. Nürnberg: Helmut Preussler Verlag.

Oto-Peralías, Daniel, and Diego Romero-Ávila. 2017. "Historical frontiers and the rise of inequality: the case of the frontier of Granada." Journal of the European Economic Association 15 (1): 54-98. 
Radvanovský, Zdeněk. 2001. "Integrationsprobleme bei der Wiederbesiedlung der deutschen Siedlungsgebiete in den böhmischen Ländern nach 1945." In Vorträge der Tagungen des Collegium Carolinum in Bad Wiessee vom 20. bis 22. November 1992 und 19. bis 21. November 1993, 143-161. München, November.

Školl, Jaroslav. 1983. Nové osídlení okresu Břeclav po roce 1945. Mikulov: Okresní archív Břeclav.

Spurný, Matěj. 2011. Nejsou jako my: Česká společnost a menšiny v pohraničí 1945-1960. Praha: Antikomplex.

Staněk, Tomáš. 1991. Odsun Němců z Československa, 1945-1947. Academia.

Testa, Patrick A. 2019. “The Economic Legacy of Expulsion: Lessons from Post-war Czechoslovakia." Manuscript, Department of Economics, University of California, Irvine.

Vaněk, Miroslav. 1996. Nedalo se tady dýchat: Ekologie v českých zemích v letech 1968 až 1989. Praha: Ústav pro soudobé dějiny AV ČR.

Waldinger, Fabian. 2010. "Quality matters: The expulsion of professors and the consequences for PhD student outcomes in Nazi Germany." Journal of Political Economy 118 (4): 787-831.

- 2011. "Peer effects in science: Evidence from the dismissal of scientists in Nazi Germany." The Review of Economic Studies 79 (2): 838-861.

- 2016. "Bombs, brains, and science: The role of human and physical capital for the creation of scientific knowledge." Review of Economics and Statistics 98 (5): 811-831.

Wiedemann, Andreas. 2016. "Pojd's námi budovat pohraničí!": osídlování a proměna obyvatelstva bývalých Sudet 1945-1952. Prague.

Wilson, Margaret FJ, Brian O’Connell, Colin Brown, Janine C Guinan, and Anthony J Grehan. 2007. "Multiscale terrain analysis of multibeam bathymetry data for habitat mapping on the continental slope." Marine Geodesy 30 (1-2): 3-35. 
Old sins cast long shadows: The Long-term impact of the resettlement of the Sudetenland on residential migration

Appendix 
A Appendix: Additional Figures and Tables 
Figure A.1: Origins of settlers in Břeclav area

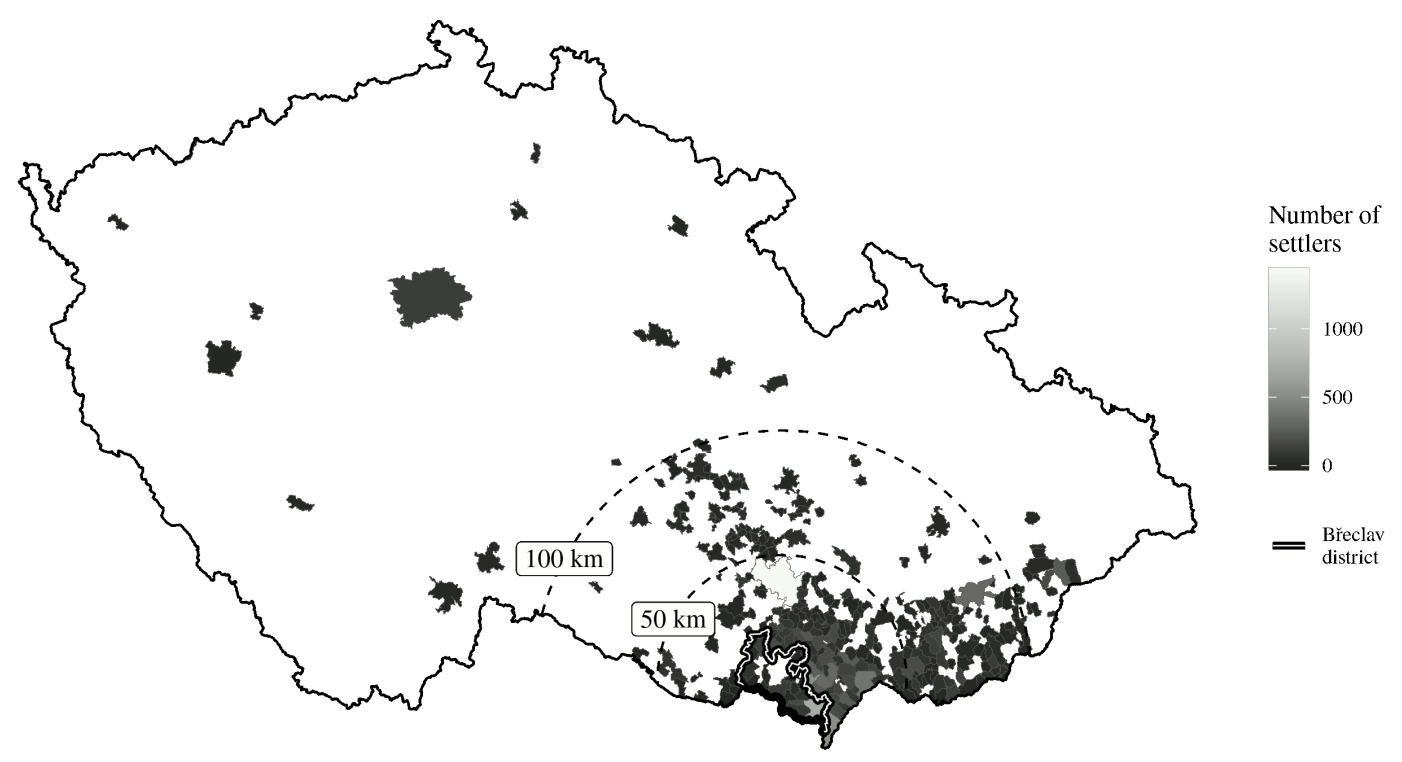

Source: Školl (1983), own elaboration. 
Figure A.2: The ethnic border and district borders

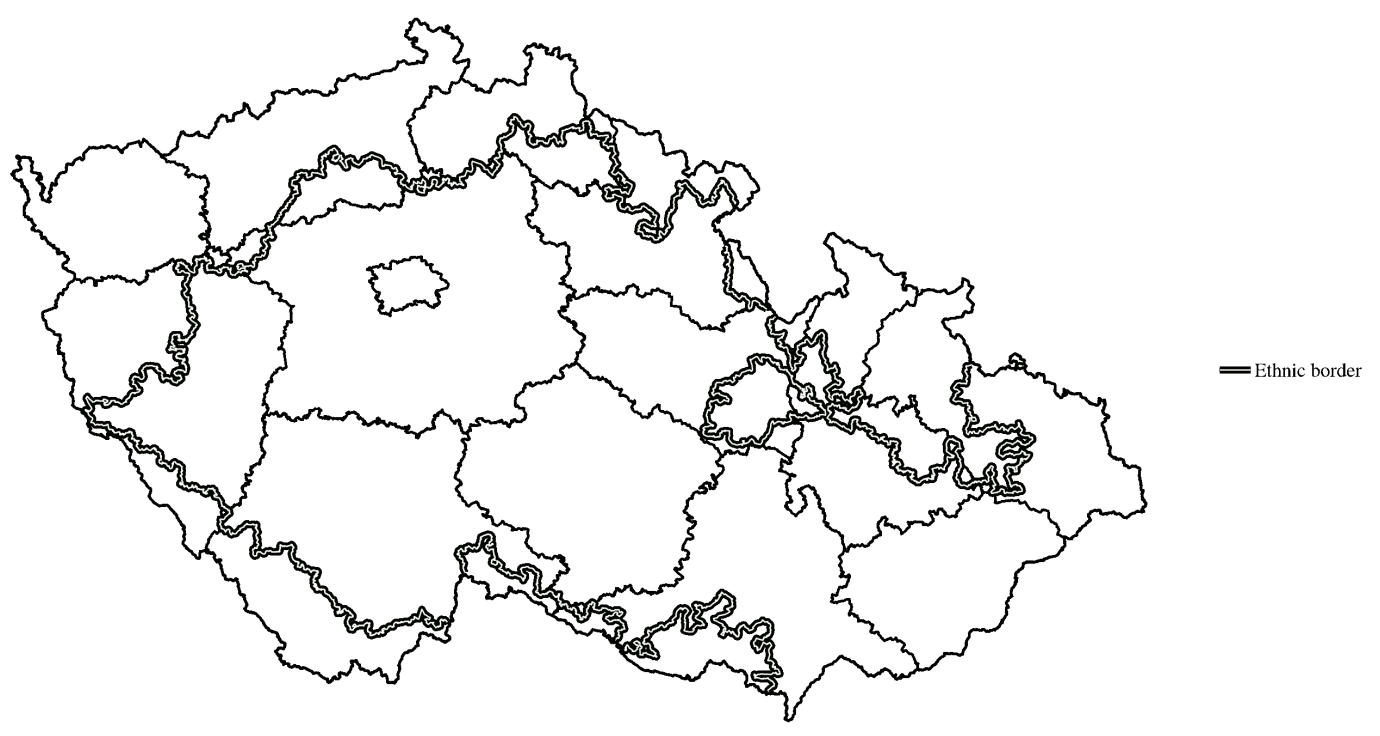

Figure A.3: The ethnic border and border of the German Reich 1938-1945

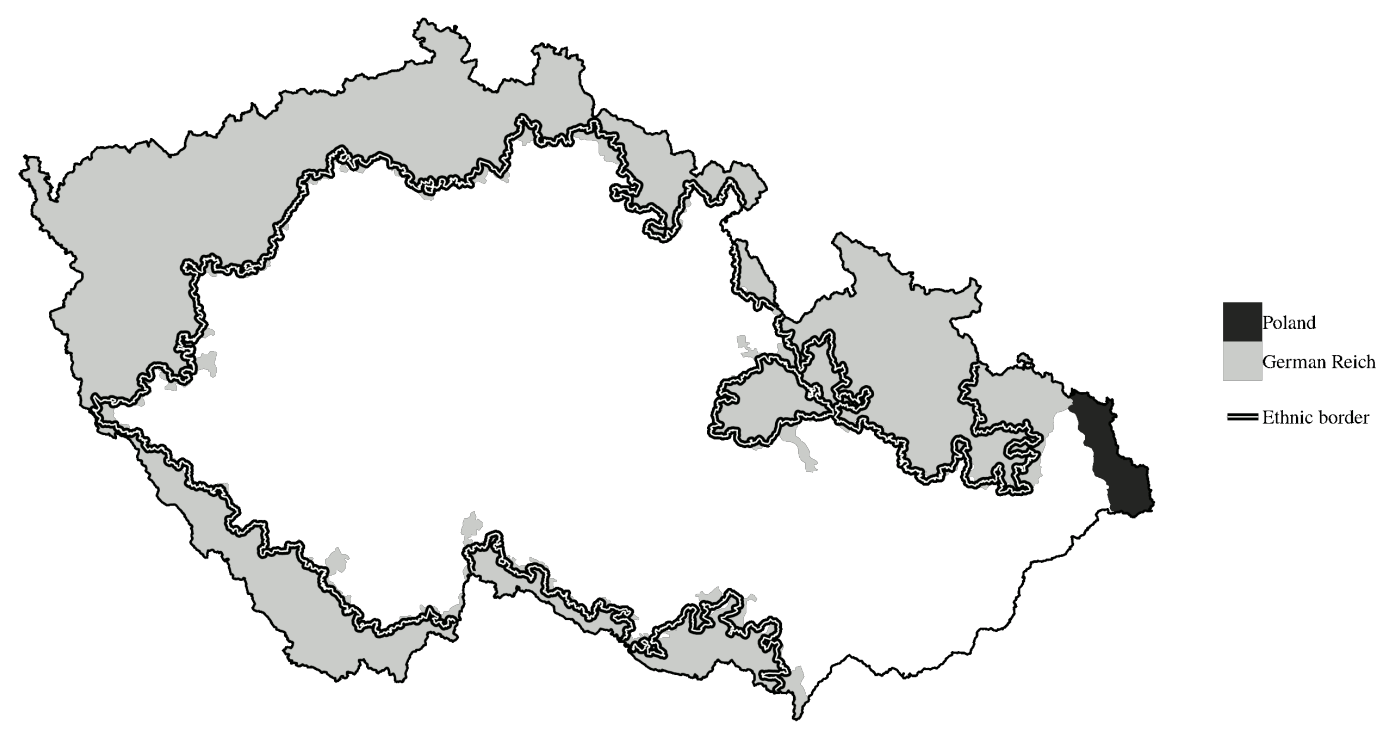

Note: The areas of today's Czech Republic annexed by Poland and the German Reich as a consequence of the Munich Agreement were obtained from the map "Sudetenland" published by Kartographische Anstalt Freytag und Berndt in 1938. 
Table A.1: Resettlement process in Břeclav area: Number and share of settlers by the distance of origin

\begin{tabular}{|c|c|c|c|c|c|c|}
\hline \multirow[t]{3}{*}{ Settlement } & \multicolumn{4}{|c|}{ Settlers from Czech Republic by the distance of origin } & \multirow{2}{*}{$\begin{array}{c}\text { Total } \\
\text { Settlers }\end{array}$} & \multirow{2}{*}{$\begin{array}{c}\text { Total } \\
\text { Population }\end{array}$} \\
\hline & $\leq 5 \mathrm{~km}$ & $\leq 10 \mathrm{~km}$ & $\leq 30 \mathrm{~km}$ & $\leq 100 \mathrm{~km}$ & & \\
\hline & (1) & (2) & (3) & (4) & $(5)$ & (6) \\
\hline Břeclav & $195(4.4 \%)$ & $875(19.5 \%)$ & $1,719(38.4 \%)$ & $2,930(65.5 \%)$ & 4,476 & 11,010 \\
\hline Valtice & $112(5.8 \%)$ & $290(15.1 \%)$ & $712(37.2 \%)$ & $956(49.9 \%)$ & 1,915 & 3,000 \\
\hline Hustopeče & $70(5.0 \%)$ & $349(25.0 \%)$ & $756(54.2 \%)$ & $922(66.1 \%)$ & 1,395 & 2,652 \\
\hline Dolní Dunajovice & $0(0.0 \%)$ & $0(0.0 \%)$ & $302(25.4 \%)$ & $654(55.0 \%)$ & 1,190 & 1,689 \\
\hline Lednice & $126(10.7 \%)$ & $299(25.4 \%)$ & $584(49.5 \%)$ & $792(67.2 \%)$ & 1,179 & 1,740 \\
\hline Pohořelice & $98(10.0 \%)$ & $326(33.4 \%)$ & $728(74.6 \%)$ & $924(94.7 \%)$ & 976 & 2,961 \\
\hline Drnholec & $0(0.0 \%)$ & $0(0.0 \%)$ & $27(2.9 \%)$ & $528(56.4 \%)$ & 937 & 1,484 \\
\hline Mikulov & $0(0.0 \%)$ & $0(0.0 \%)$ & $8(0.9 \%)$ & $444(47.4 \%)$ & 937 & 5,337 \\
\hline Novosedly & $0(0.0 \%)$ & $0(0.0 \%)$ & $25(2.7 \%)$ & $387(41.3 \%)$ & 936 & 1,062 \\
\hline Zaječí & $213(23.3 \%)$ & $389(42.6 \%)$ & $660(72.3 \%)$ & $724(79.3 \%)$ & 913 & 1,214 \\
\hline Popice & $35(3.9 \%)$ & $146(16.3 \%)$ & $640(71.3 \%)$ & $674(75.1 \%)$ & 897 & 979 \\
\hline Vlasatice & $13(1.6 \%)$ & $54(6.5 \%)$ & $107(12.8 \%)$ & $457(54.6 \%)$ & 837 & 988 \\
\hline Pouzdřany & $138(18.7 \%)$ & $177(24.0 \%)$ & $276(37.4 \%)$ & $505(68.4 \%)$ & 738 & 1,067 \\
\hline Sedlec & $0(0.0 \%)$ & $34(5.2 \%)$ & $164(25.3 \%)$ & $405(62.5 \%)$ & 648 & 803 \\
\hline Strachotín & $65(10.0 \%)$ & $65(10.0 \%)$ & $402(62.1 \%)$ & $451(69.7 \%)$ & 647 & 789 \\
\hline Jevišovka & $0(0.0 \%)$ & $0(0.0 \%)$ & $23(3.7 \%)$ & $72(11.5 \%)$ & 627 & 808 \\
\hline Perná & $0(0.0 \%)$ & $0(0.0 \%)$ & $34(5.6 \%)$ & $111(18.3 \%)$ & 608 & 776 \\
\hline Starovice & $0(0.0 \%)$ & $327(55.0 \%)$ & $453(76.1 \%)$ & $468(78.7 \%)$ & 595 & 742 \\
\hline Přítluky & $329(56.9 \%)$ & $419(72.5 \%)$ & $477(82.5 \%)$ & $502(86.9 \%)$ & 578 & 745 \\
\hline Bulhary & $6(1.1 \%)$ & $63(11.2 \%)$ & $204(36.1 \%)$ & $437(77.3 \%)$ & 565 & 708 \\
\hline Horní Věstonice & $0(0.0 \%)$ & $0(0.0 \%)$ & $161(31.1 \%)$ & $348(67.3 \%)$ & 517 & 549 \\
\hline Mušov & $27(5.4 \%)$ & $33(6.5 \%)$ & $129(25.6 \%)$ & $356(70.6 \%)$ & 504 & 559 \\
\hline Březí & $0(0.0 \%)$ & $0(0.0 \%)$ & $54(11.4 \%)$ & $272(57.4 \%)$ & 474 & 1,208 \\
\hline Pavlov & $0(0.0 \%)$ & $0(0.0 \%)$ & $69(15.2 \%)$ & $245(53.8 \%)$ & 455 & 658 \\
\hline Brod nad Dyjí & $0(0.0 \%)$ & $0(0.0 \%)$ & $103(23.4 \%)$ & $275(62.5 \%)$ & 440 & 587 \\
\hline Poštorná & $84(19.2 \%)$ & $122(27.9 \%)$ & $159(36.3 \%)$ & $243(55.5 \%)$ & 438 & 3,073 \\
\hline Nový Přerov & $5(1.2 \%)$ & $5(1.2 \%)$ & $18(4.3 \%)$ & $23(5.4 \%)$ & 423 & 510 \\
\hline Cvrčovice & $42(11.1 \%)$ & $42(11.1 \%)$ & $97(25.7 \%)$ & $138(36.5 \%)$ & 378 & 591 \\
\hline Úvaly & $0(0.0 \%)$ & $0(0.0 \%)$ & $89(25.6 \%)$ & $207(59.7 \%)$ & 347 & n.a. \\
\hline Milovice & $16(4.7 \%)$ & $21(6.2 \%)$ & $114(33.7 \%)$ & $237(70.1 \%)$ & 338 & 425 \\
\hline Klentnice & $0(0.0 \%)$ & $0(0.0 \%)$ & $54(16.4 \%)$ & $245(74.5 \%)$ & 329 & 373 \\
\hline Bavory & $0(0.0 \%)$ & $0(0.0 \%)$ & $31(10.7 \%)$ & $145(49.8 \%)$ & 291 & 342 \\
\hline Dolní Věstonice & $0(0.0 \%)$ & $0(0.0 \%)$ & $99(40.4 \%)$ & $149(60.8 \%)$ & 245 & 412 \\
\hline Dobré Pole & $0(0.0 \%)$ & $0(0.0 \%)$ & $36(15.7 \%)$ & $73(31.9 \%)$ & 229 & 460 \\
\hline Charvatská Nová Ves & $76(34.2 \%)$ & $132(59.5 \%)$ & $144(64.9 \%)$ & $153(68.9 \%)$ & 222 & 1,725 \\
\hline Nová Ves & $120(55.6 \%)$ & $153(70.8 \%)$ & $216(100.0 \%)$ & $279(129.2 \%)$ & 216 & 269 \\
\hline Smolín & $5(2.4 \%)$ & $19(9.3 \%)$ & $31(15.1 \%)$ & $102(49.8 \%)$ & 205 & 304 \\
\hline Nejdek & $8(4.5 \%)$ & $37(20.7 \%)$ & $121(67.6 \%)$ & $136(76.0 \%)$ & 179 & 212 \\
\hline Pasohlávky & $0(0.0 \%)$ & $0(0.0 \%)$ & $31(21.8 \%)$ & $54(38.0 \%)$ & 142 & 282 \\
\hline Nové Mlýny & $4(4.3 \%)$ & $8(8.6 \%)$ & $57(61.3 \%)$ & $57(61.3 \%)$ & 93 & 143 \\
\hline Hlohovec & $3(5.6 \%)$ & $19(35.2 \%)$ & $21(38.9 \%)$ & $25(46.3 \%)$ & 54 & 1,307 \\
\hline Kurdějov & $15(60.0 \%)$ & $16(64.0 \%)$ & $21(84.0 \%)$ & $21(84.0 \%)$ & 25 & 524 \\
\hline Total & $1,805(6.4 \%)$ & $4,420(15.7 \%)$ & $10,156(36.1 \%)$ & $17,126(60.9 \%)$ & 28,138 & 55,067 \\
\hline
\end{tabular}

Source: Školl (1983), own elaboration. 
Table A.2: Resettlement process in Břeclav area: Number and share of settlers from 4 most important settlements of origin within Czech Republic

\begin{tabular}{|c|c|c|c|c|c|c|}
\hline \multirow[t]{3}{*}{ Settlement } & \multicolumn{4}{|c|}{ Settlers from $n$ most important origins } & \multirow{2}{*}{$\begin{array}{c}\text { Total } \\
\text { Settlers }\end{array}$} & \multirow{2}{*}{$\begin{array}{c}\text { Total } \\
\text { Population }\end{array}$} \\
\hline & $n=1$ & $n=2$ & $n=3$ & $n=4$ & & \\
\hline & (1) & (2) & (3) & (4) & (5) & (6) \\
\hline Břeclav & $416(9.3 \%)$ & $677(15.1 \%)$ & $935(20.9 \%)$ & $1,091(24.4 \%)$ & 4,476 & 11,010 \\
\hline Valtice & $125(6.5 \%)$ & $224(11.7 \%)$ & $301(15.7 \%)$ & $367(19.2 \%)$ & 1,915 & 3,000 \\
\hline Hustopeče & $85(6.1 \%)$ & $159(11.4 \%)$ & $229(16.4 \%)$ & $294(21.1 \%)$ & 1,395 & 2,652 \\
\hline Dolní Dunajovice & $122(10.3 \%)$ & $203(17.0 \%)$ & $249(20.9 \%)$ & $291(24.4 \%)$ & 1,190 & 1,689 \\
\hline Lednice & $70(5.9 \%)$ & $120(10.2 \%)$ & $170(14.4 \%)$ & $218(18.5 \%)$ & 1,179 & 1,740 \\
\hline Pohořelice & $131(13.4 \%)$ & $262(26.8 \%)$ & $296(30.3 \%)$ & $330(33.8 \%)$ & 976 & 2,961 \\
\hline Drnholec & $99(10.6 \%)$ & $195(20.8 \%)$ & $237(25.3 \%)$ & $272(29.0 \%)$ & 937 & 1,484 \\
\hline Mikulov & $54(5.7 \%)$ & $92(9.8 \%)$ & $130(13.9 \%)$ & $161(17.2 \%)$ & 937 & 5,337 \\
\hline Novosedly & $88(9.4 \%)$ & $137(14.6 \%)$ & $177(18.9 \%)$ & $216(23.1 \%)$ & 936 & 1,062 \\
\hline Zaječí & $161(17.6 \%)$ & $250(27.4 \%)$ & $302(33.1 \%)$ & $350(38.3 \%)$ & 913 & 1,214 \\
\hline Popice & $123(13.7 \%)$ & $184(20.5 \%)$ & $239(26.6 \%)$ & $293(32.7 \%)$ & 897 & 979 \\
\hline Vlasatice & $48(5.7 \%)$ & $87(10.4 \%)$ & $119(14.2 \%)$ & $150(17.9 \%)$ & 837 & 988 \\
\hline Pouzdřany & $95(12.9 \%)$ & $128(17.3 \%)$ & $161(21.8 \%)$ & $191(25.9 \%)$ & 738 & 1,067 \\
\hline Sedlec & $51(7.9 \%)$ & $91(14.0 \%)$ & $120(18.5 \%)$ & $144(22.2 \%)$ & 648 & 803 \\
\hline Strachotín & $100(15.5 \%)$ & $177(27.4 \%)$ & $242(37.4 \%)$ & $277(42.8 \%)$ & 647 & 789 \\
\hline Jevišovka & $11(1.8 \%)$ & $21(3.3 \%)$ & $29(4.6 \%)$ & $37(5.9 \%)$ & 627 & 808 \\
\hline Perná & $176(28.9 \%)$ & $210(34.6 \%)$ & $233(38.4 \%)$ & $256(42.2 \%)$ & 608 & 776 \\
\hline Starovice & $74(12.4 \%)$ & $146(24.5 \%)$ & $208(35.0 \%)$ & $269(45.2 \%)$ & 595 & 742 \\
\hline Přítluky & $329(56.9 \%)$ & $370(64.0 \%)$ & $393(68.0 \%)$ & $413(71.5 \%)$ & 578 & 745 \\
\hline Bulhary & $41(7.3 \%)$ & $82(14.5 \%)$ & $117(20.7 \%)$ & $152(26.9 \%)$ & 565 & 708 \\
\hline Horní Věstonice & $107(20.7 \%)$ & $207(40.0 \%)$ & $241(46.6 \%)$ & $268(51.8 \%)$ & 517 & 549 \\
\hline Mušov & $38(7.5 \%)$ & $69(13.7 \%)$ & $92(18.3 \%)$ & $114(22.6 \%)$ & 504 & 559 \\
\hline Březí & $34(7.3 \%)$ & $69(14.5 \%)$ & $99(21.0 \%)$ & $130(27.4 \%)$ & 474 & 1,208 \\
\hline Pavlov & $57(12.6 \%)$ & $99(21.9 \%)$ & $119(26.1 \%)$ & $134(29.4 \%)$ & 455 & 658 \\
\hline Brod nad Dyjí & $46(10.4 \%)$ & $88(20.0 \%)$ & $130(29.6 \%)$ & $157(35.7 \%)$ & 440 & 587 \\
\hline Poštorná & $51(11.6 \%)$ & $84(19.2 \%)$ & $109(24.9 \%)$ & $128(29.2 \%)$ & 438 & 3,073 \\
\hline Nový Přerov & $21(5.0 \%)$ & $26(6.1 \%)$ & $31(7.3 \%)$ & $36(8.5 \%)$ & 423 & 510 \\
\hline Cvrčovice & $49(13.0 \%)$ & $72(19.0 \%)$ & $86(22.8 \%)$ & $95(25.1 \%)$ & 378 & 591 \\
\hline Úvaly & $29(8.4 \%)$ & $54(15.6 \%)$ & $78(22.5 \%)$ & $98(28.2 \%)$ & 347 & n.a. \\
\hline Milovice & $33(9.8 \%)$ & $55(16.3 \%)$ & $75(22.2 \%)$ & $93(27.5 \%)$ & 338 & 425 \\
\hline Klentnice & $69(20.9 \%)$ & $103(31.4 \%)$ & $134(40.7 \%)$ & $165(50.0 \%)$ & 329 & 373 \\
\hline Bavory & $73(25.0 \%)$ & $107(36.8 \%)$ & $134(46.0 \%)$ & $153(52.6 \%)$ & 291 & 342 \\
\hline Dolní Věstonice & $42(17.2 \%)$ & $77(31.2 \%)$ & $92(37.5 \%)$ & $103(42.2 \%)$ & 245 & 412 \\
\hline Dobré Pole & $40(17.5 \%)$ & $65(28.4 \%)$ & $77(33.6 \%)$ & $88(38.4 \%)$ & 229 & 460 \\
\hline Charvatská Nová Ves & $55(24.8 \%)$ & $82(36.9 \%)$ & $103(46.4 \%)$ & $122(55.0 \%)$ & 222 & 1,725 \\
\hline Nová Ves & $17(7.9 \%)$ & $34(15.7 \%)$ & $51(23.6 \%)$ & $67(31.0 \%)$ & 216 & 269 \\
\hline Smolín & $28(13.7 \%)$ & $40(19.5 \%)$ & $50(24.4 \%)$ & $57(27.8 \%)$ & 205 & 304 \\
\hline Nejdek & $33(18.4 \%)$ & $53(29.6 \%)$ & $68(38.0 \%)$ & $82(45.8 \%)$ & 179 & 212 \\
\hline Pasohlávky & $19(13.5 \%)$ & $34(24.3 \%)$ & $46(32.3 \%)$ & $54(37.7 \%)$ & 142 & 282 \\
\hline Nové Mlýny & $29(31.2 \%)$ & $37(39.8 \%)$ & $44(47.3 \%)$ & $49(52.7 \%)$ & 93 & 143 \\
\hline Hlohovec & $10(18.5 \%)$ & $14(25.9 \%)$ & $17(31.5 \%)$ & $20(37.0 \%)$ & 54 & 1,307 \\
\hline Kurdějov & $8(32.0 \%)$ & $16(62.6 \%)$ & $20(78.6 \%)$ & $24(94.6 \%)$ & 25 & 524 \\
\hline Total & $3,288(11.7 \%)$ & $5,300(18.8 \%)$ & $6,783(24.1 \%)$ & $8,007(28.5 \%)$ & 28,138 & 55,067 \\
\hline
\end{tabular}

Source: Školl (1983), own elaboration. 
Table A.3: Resettlement process in Břeclav area: Number and share of settlers by country of origin

\begin{tabular}{|c|c|c|c|c|c|c|c|c|c|}
\hline \multirow[t]{2}{*}{ Settlement } & $\begin{array}{c}\text { Czech } \\
\text { Republic }\end{array}$ & Bulgaria & Slovakia & $\begin{array}{l}\text { Soviet } \\
\text { Union }\end{array}$ & Yugoslavia & Austria & Other & $\begin{array}{c}\text { Total } \\
\text { Settlers }\end{array}$ & $\begin{array}{c}\text { Total } \\
\text { Population }\end{array}$ \\
\hline & (1) & (2) & (3) & (4) & (5) & (6) & (7) & (8) & (9) \\
\hline Břeclav & $4,181(93.4 \%)$ & $3(0.1 \%)$ & $0(0.0 \%)$ & $17(0.4 \%)$ & $7(0.2 \%)$ & $62(1.4 \%)$ & $27(0.6 \%)$ & 4,476 & 11,010 \\
\hline Valtice & $1,486(77.6 \%)$ & $7(0.4 \%)$ & $88(4.6 \%)$ & $3(0.2 \%)$ & $17(0.9 \%)$ & $55(2.9 \%)$ & $39(2.0 \%)$ & 1,915 & 3,000 \\
\hline Hustopeče & $1,323(94.8 \%)$ & $1(0.1 \%)$ & $4(0.3 \%)$ & $10(0.7 \%)$ & $6(0.4 \%)$ & $15(1.1 \%)$ & $8(0.6 \%)$ & 1,395 & 2,652 \\
\hline Dolní Dunajovice & $1,102(92.6 \%)$ & $0(0.0 \%)$ & $8(0.7 \%)$ & $13(1.1 \%)$ & $5(0.4 \%)$ & $2(0.2 \%)$ & $1(0.1 \%)$ & 1,190 & 1,689 \\
\hline Lednice & $992(84.1 \%)$ & $7(0.6 \%)$ & $27(2.3 \%)$ & $0(0.0 \%)$ & $50(4.2 \%)$ & $25(2.1 \%)$ & $9(0.8 \%)$ & 1,179 & 1,740 \\
\hline Pohořelice & $809(82.9 \%)$ & $4(0.4 \%)$ & $48(4.9 \%)$ & $61(6.2 \%)$ & $3(0.3 \%)$ & $12(1.2 \%)$ & $11(1.1 \%)$ & 976 & 2,961 \\
\hline Drnholec & $815(87.0 \%)$ & $11(1.2 \%)$ & $77(8.2 \%)$ & $0(0.0 \%)$ & $0(0.0 \%)$ & $31(3.3 \%)$ & $4(0.4 \%)$ & 937 & 1,484 \\
\hline Mikulov & $796(85.0 \%)$ & $2(0.2 \%)$ & $19(2.0 \%)$ & $2(0.2 \%)$ & $20(2.1 \%)$ & $1(0.1 \%)$ & $7(0.7 \%)$ & 937 & 5,337 \\
\hline Novosedly & $785(83.9 \%)$ & $81(8.7 \%)$ & $18(1.9 \%)$ & $0(0.0 \%)$ & $33(3.5 \%)$ & $3(0.3 \%)$ & $4(0.4 \%)$ & 936 & 1,062 \\
\hline Zaječí & $860(94.2 \%)$ & $0(0.0 \%)$ & $15(1.6 \%)$ & $4(0.4 \%)$ & $0(0.0 \%)$ & $9(1.0 \%)$ & $14(1.5 \%)$ & 913 & 1,214 \\
\hline Popice & $873(97.3 \%)$ & $0(0.0 \%)$ & $0(0.0 \%)$ & $19(2.1 \%)$ & $0(0.0 \%)$ & $2(0.2 \%)$ & $2(0.2 \%)$ & 897 & 979 \\
\hline Vlasatice & $676(80.8 \%)$ & $22(2.6 \%)$ & $59(7.0 \%)$ & $32(3.8 \%)$ & $8(1.0 \%)$ & $2(0.2 \%)$ & $3(0.4 \%)$ & 837 & 988 \\
\hline Pouzdřany & $707(95.8 \%)$ & $0(0.0 \%)$ & $4(0.5 \%)$ & $11(1.5 \%)$ & $0(0.0 \%)$ & $0(0.0 \%)$ & $3(0.4 \%)$ & 738 & 1,067 \\
\hline Sedlec & $564(87.0 \%)$ & $0(0.0 \%)$ & $17(2.6 \%)$ & $0(0.0 \%)$ & $46(7.1 \%)$ & $2(0.3 \%)$ & $6(0.9 \%)$ & 648 & 803 \\
\hline Strachotín & $588(90.9 \%)$ & $0(0.0 \%)$ & $12(1.9 \%)$ & $47(7.3 \%)$ & $0(0.0 \%)$ & $1(0.2 \%)$ & $0(0.0 \%)$ & 647 & 789 \\
\hline Jevišovka & $158(25.2 \%)$ & $445(71.0 \%)$ & $5(0.8 \%)$ & $0(0.0 \%)$ & $13(2.1 \%)$ & $0(0.0 \%)$ & $2(0.3 \%)$ & 627 & 808 \\
\hline Perná & $513(84.4 \%)$ & $0(0.0 \%)$ & $4(0.7 \%)$ & $1(0.2 \%)$ & $2(0.3 \%)$ & $1(0.2 \%)$ & $1(0.2 \%)$ & 608 & 776 \\
\hline Starovice & $589(99.0 \%)$ & $0(0.0 \%)$ & $0(0.0 \%)$ & $4(0.7 \%)$ & $0(0.0 \%)$ & $0(0.0 \%)$ & $0(0.0 \%)$ & 595 & 742 \\
\hline Př́ítluky & $561(97.1 \%)$ & $0(0.0 \%)$ & $6(1.0 \%)$ & $0(0.0 \%)$ & $0(0.0 \%)$ & $0(0.0 \%)$ & $2(0.3 \%)$ & 578 & 745 \\
\hline Bulhary & $544(96.3 \%)$ & $0(0.0 \%)$ & $5(0.9 \%)$ & $1(0.2 \%)$ & $0(0.0 \%)$ & $3(0.5 \%)$ & $3(0.5 \%)$ & 565 & 708 \\
\hline Horní Věstonice & $497(96.1 \%)$ & $0(0.0 \%)$ & $8(1.5 \%)$ & $0(0.0 \%)$ & $0(0.0 \%)$ & $4(0.8 \%)$ & $4(0.8 \%)$ & 517 & 549 \\
\hline Mušov & $470(93.3 \%)$ & $10(2.0 \%)$ & $8(1.6 \%)$ & $0(0.0 \%)$ & $2(0.4 \%)$ & $2(0.4 \%)$ & $0(0.0 \%)$ & 504 & 559 \\
\hline Březí & $398(84.0 \%)$ & $0(0.0 \%)$ & $4(0.8 \%)$ & $1(0.2 \%)$ & $18(3.8 \%)$ & $0(0.0 \%)$ & $0(0.0 \%)$ & 474 & 1,208 \\
\hline Pavlov & $398(87.5 \%)$ & $0(0.0 \%)$ & $15(3.3 \%)$ & $0(0.0 \%)$ & $0(0.0 \%)$ & $0(0.0 \%)$ & $4(0.9 \%)$ & 455 & 658 \\
\hline Brod nad Dyjí & $421(95.7 \%)$ & $4(0.9 \%)$ & $15(3.4 \%)$ & $0(0.0 \%)$ & $0(0.0 \%)$ & $0(0.0 \%)$ & $0(0.0 \%)$ & 440 & 587 \\
\hline Poštorná & $400(91.3 \%)$ & $0(0.0 \%)$ & $6(1.4 \%)$ & $4(0.9 \%)$ & $0(0.0 \%)$ & $6(1.4 \%)$ & $1(0.2 \%)$ & 438 & 3,073 \\
\hline Nový Přerov & $91(21.5 \%)$ & $327(77.3 \%)$ & $1(0.2 \%)$ & $0(0.0 \%)$ & $0(0.0 \%)$ & $0(0.0 \%)$ & $1(0.2 \%)$ & 423 & 510 \\
\hline Cvrčovice & $248(65.6 \%)$ & $0(0.0 \%)$ & $23(6.1 \%)$ & $83(22.0 \%)$ & $11(2.9 \%)$ & $1(0.3 \%)$ & $2(0.5 \%)$ & 378 & 591 \\
\hline Úvaly & $333(96.0 \%)$ & $0(0.0 \%)$ & $14(4.0 \%)$ & $0(0.0 \%)$ & $0(0.0 \%)$ & $0(0.0 \%)$ & $0(0.0 \%)$ & 347 & n.a. \\
\hline Milovice & $335(99.1 \%)$ & $0(0.0 \%)$ & $3(0.9 \%)$ & $0(0.0 \%)$ & $0(0.0 \%)$ & $0(0.0 \%)$ & $0(0.0 \%)$ & 338 & 425 \\
\hline Klentnice & $321(97.6 \%)$ & $0(0.0 \%)$ & $0(0.0 \%)$ & $0(0.0 \%)$ & $2(0.6 \%)$ & $0(0.0 \%)$ & $0(0.0 \%)$ & 329 & 373 \\
\hline Bavory & $272(93.5 \%)$ & $0(0.0 \%)$ & $0(0.0 \%)$ & $11(3.8 \%)$ & $8(2.7 \%)$ & $0(0.0 \%)$ & $0(0.0 \%)$ & 291 & 342 \\
\hline Dolní Věstonice & $272(111.0 \%)$ & $0(0.0 \%)$ & $4(1.6 \%)$ & $0(0.0 \%)$ & $4(1.6 \%)$ & $0(0.0 \%)$ & $4(1.6 \%)$ & 245 & 412 \\
\hline Dobré Pole & $176(76.9 \%)$ & $0(0.0 \%)$ & $1(0.4 \%)$ & $0(0.0 \%)$ & $20(8.7 \%)$ & $14(6.1 \%)$ & $0(0.0 \%)$ & 229 & 460 \\
\hline Charvatská Nová Ves & $215(96.8 \%)$ & $0(0.0 \%)$ & $4(1.8 \%)$ & $0(0.0 \%)$ & $0(0.0 \%)$ & $3(1.4 \%)$ & $0(0.0 \%)$ & 222 & 1,725 \\
\hline Nová Ves & $158(73.1 \%)$ & $6(2.8 \%)$ & $17(7.9 \%)$ & $7(3.2 \%)$ & $0(0.0 \%)$ & $0(0.0 \%)$ & $20(9.3 \%)$ & 216 & 269 \\
\hline Smolín & $158(77.1 \%)$ & $0(0.0 \%)$ & $0(0.0 \%)$ & $47(22.9 \%)$ & $0(0.0 \%)$ & $0(0.0 \%)$ & $0(0.0 \%)$ & 205 & 304 \\
\hline Nejdek & $161(89.9 \%)$ & $0(0.0 \%)$ & $7(3.9 \%)$ & $4(2.2 \%)$ & $4(2.2 \%)$ & $0(0.0 \%)$ & $3(1.7 \%)$ & 179 & 212 \\
\hline Pasohlávky & $103(72.5 \%)$ & $0(0.0 \%)$ & $27(19.0 \%)$ & $0(0.0 \%)$ & $0(0.0 \%)$ & $11(7.7 \%)$ & $0(0.0 \%)$ & 142 & 282 \\
\hline Nové Mlýny & $85(91.4 \%)$ & $0(0.0 \%)$ & $5(5.4 \%)$ & $0(0.0 \%)$ & $0(0.0 \%)$ & $1(1.1 \%)$ & $2(2.2 \%)$ & 93 & 143 \\
\hline Hlohovec & $43(79.6 \%)$ & $0(0.0 \%)$ & $1(1.9 \%)$ & $1(1.9 \%)$ & $0(0.0 \%)$ & $0(0.0 \%)$ & $0(0.0 \%)$ & 54 & 1,307 \\
\hline Kurdějov & $117(468.0 \%)$ & $0(0.0 \%)$ & $0(0.0 \%)$ & $0(0.0 \%)$ & $0(0.0 \%)$ & $8(32.0 \%)$ & $0(0.0 \%)$ & 25 & 524 \\
\hline Total & $24,594(90.3 \%)$ & $930(3.4 \%)$ & $579(2.1 \%)$ & $383(1.4 \%)$ & $279(1.0 \%)$ & $276(1.0 \%)$ & $187(0.7 \%)$ & 28,138 & 55,067 \\
\hline
\end{tabular}

Source: Školl (1983), own elaboration. Note: Category "other" covers settlers from Poland, Germany, Romania, France, Hungary, Argentina, United Kingdom, Italy, Norway, Canada, Israel, Ecuador and United States. 
Figure A.4: Discontinuity plots of migration rates and election turnout at the ethnic border

(a) Emigration rate

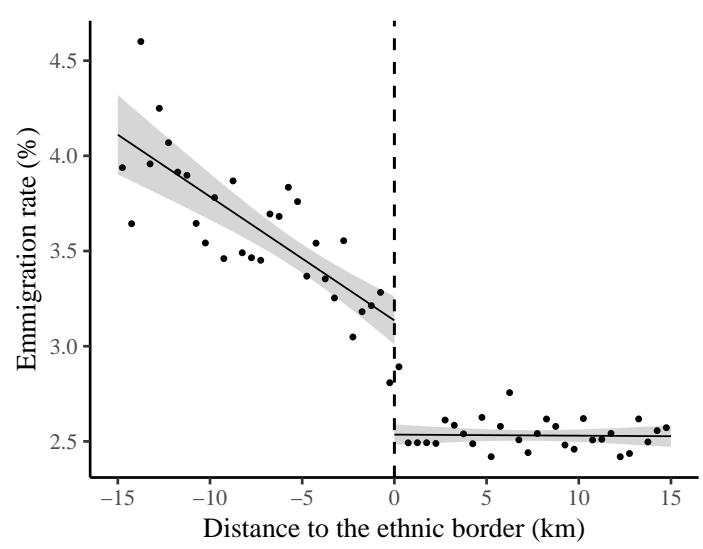

(c) Net immigration rate

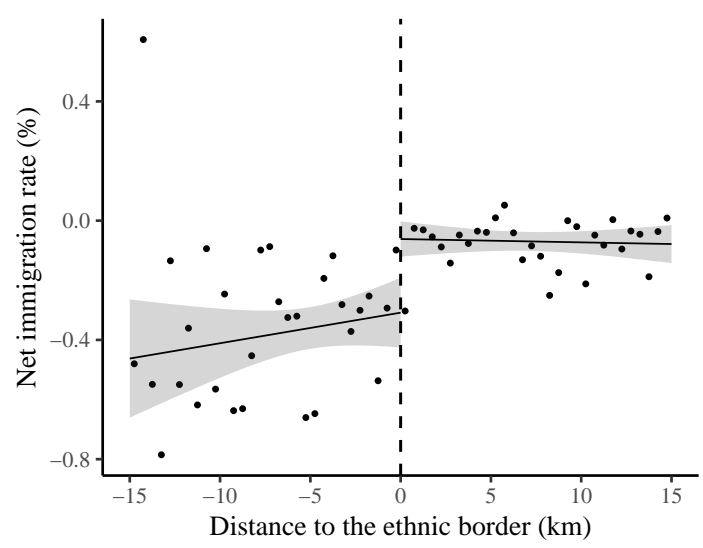

(b) Immigration rate

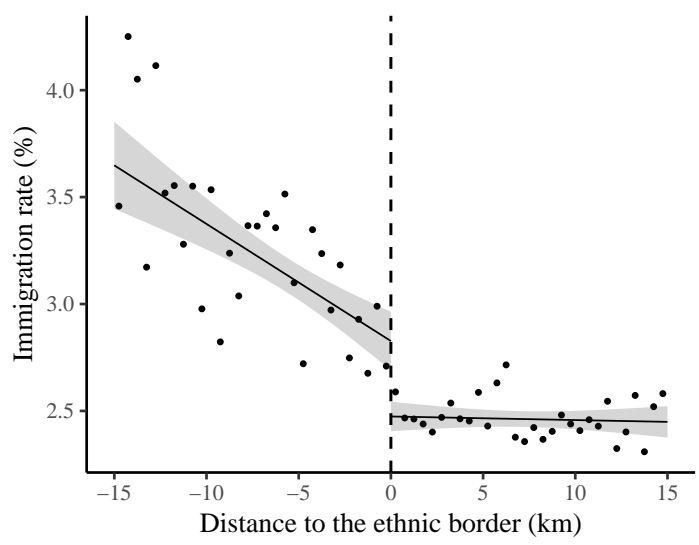

(d) Turnout in municipal elections

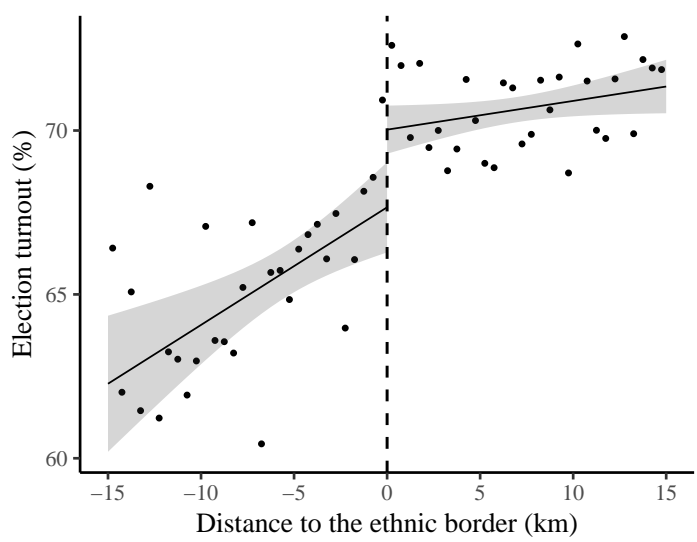

Source: CZSO, SRTM, own calculations.

Note: New settlements have negative distances to the ethnic border, and old settlements have a positive one. Settlements are aggregated to bins of $0.5 \mathrm{~km}$ represented by points. The smoothing lines are parametric linear predictions and shaded areas represent $95 \%$ confidence intervals. 
Table A.4: Descriptive statistics: Estimation samples

\begin{tabular}{|c|c|c|c|c|c|c|c|c|c|c|c|c|c|}
\hline & & \multicolumn{9}{|c|}{ Matching strategy } & \multicolumn{3}{|c|}{ RD strategy } \\
\hline & & \multicolumn{3}{|c|}{ Version 1} & \multicolumn{3}{|c|}{ Version 2} & \multicolumn{3}{|c|}{ Version 3} & \multirow[t]{2}{*}{ New } & \multirow[t]{2}{*}{ Old } & \multirow[t]{2}{*}{ Difference } \\
\hline & & New & Old & Difference & New & Old & Difference & New & Old & Difference & & & \\
\hline & & (1) & (2) & (3) & (4) & (5) & (6) & (7) & (8) & (9) & (10) & (11) & (12) \\
\hline \multicolumn{2}{|l|}{ Settlements (n) } & 46 & 41 & & 147 & 115 & & 179 & 131 & & 402 & 1,706 & \\
\hline Share of ethnic Germans $(\%)$ & 1930 & $\begin{array}{c}93.91 \\
(0.38)\end{array}$ & $\begin{array}{c}1.53 \\
(0.29)\end{array}$ & $92.38^{* 4 *}$ & $\begin{array}{c}95.08 \\
(0.24)\end{array}$ & $\begin{array}{c}1.48 \\
(0.18)\end{array}$ & $93.60^{* * s}$ & $\begin{array}{c}95.16 \\
(0.21)\end{array}$ & $\begin{array}{c}1.65 \\
(0.18)\end{array}$ & $93.51^{* * *}$ & $\begin{array}{c}95.75 \\
(0.13)\end{array}$ & $\begin{array}{c}0.85 \\
(0.04)\end{array}$ & $94.90^{s s s}$ \\
\hline \multicolumn{2}{|l|}{ Population (n) } & $\begin{array}{l}817.98 \\
(75.93)\end{array}$ & $\begin{array}{c}846.20 \\
(70.68)\end{array}$ & -28.22 & $\begin{array}{l}785.47 \\
(49.27)\end{array}$ & $\begin{array}{c}831.89 \\
(56.54)\end{array}$ & -46.42 & $\begin{array}{l}881.35 \\
(52.20)\end{array}$ & $\begin{array}{c}911.02 \\
(62.55)\end{array}$ & -29.67 & $\begin{array}{r}1,412.60 \\
(65.18)\end{array}$ & $\begin{array}{r}1,181.55 \\
(89.85)\end{array}$ & $231.05^{*}$ \\
\hline \multirow[t]{5}{*}{ Emigration rate (\%) } & 1971-1979 & $\begin{array}{c}4.09 \\
(0.10)\end{array}$ & $\begin{array}{c}3.09 \\
(0.08)\end{array}$ & $1.00^{* * *}$ & $\begin{array}{l}4.43 \\
(0.06)\end{array}$ & $\begin{array}{c}3.10 \\
(0.05)\end{array}$ & $1.33^{* * s}$ & $\begin{array}{c}4.49 \\
(0.06)\end{array}$ & $\begin{array}{c}2.95 \\
(0.05)\end{array}$ & $1.54^{* * *}$ & $\begin{array}{c}4.76 \\
(0.04)\end{array}$ & $\begin{array}{c}3.15 \\
(0.01)\end{array}$ & $1.61^{s * s}$ \\
\hline & 1980-1989 & $\begin{array}{c}3.35 \\
(0.11)\end{array}$ & $\begin{array}{c}2.90 \\
(0.08)\end{array}$ & $0.45^{* * *}$ & $\begin{array}{l}3.52 \\
(0.07)\end{array}$ & $\begin{array}{c}2.70 \\
(0.05)\end{array}$ & $0.81^{* * *}$ & $\begin{array}{c}3.61 \\
(0.06)\end{array}$ & $\begin{array}{l}2.65 \\
(0.04)\end{array}$ & $0.96^{* * *}$ & $\begin{array}{l}4.12 \\
(0.04)\end{array}$ & $\begin{array}{c}2.79 \\
(0.01)\end{array}$ & $1.34^{s s s}$ \\
\hline & 1990-1999 & $\begin{array}{c}2.78 \\
(0.08)\end{array}$ & $\begin{array}{c}2.21 \\
(0.06)\end{array}$ & $0.57^{* * *}$ & $\begin{array}{l}2.77 \\
(0.05)\end{array}$ & $\begin{array}{c}2.26 \\
(0.04)\end{array}$ & $0.50^{* * z}$ & $\begin{array}{c}2.80 \\
(0.04)\end{array}$ & $\begin{array}{c}2.30 \\
(0.04)\end{array}$ & $0.51^{* * *}$ & $\begin{array}{c}2.99 \\
(0.03)\end{array}$ & $\begin{array}{c}2.29 \\
(0.01)\end{array}$ & $0.70^{s s s}$ \\
\hline & 2000-2009 & $\begin{array}{l}2.58 \\
(0.07)\end{array}$ & $\begin{array}{l}2.08 \\
(0.06)\end{array}$ & $0.50^{* * *}$ & $\begin{array}{c}2.69 \\
(0.05)\end{array}$ & $\begin{array}{l}2.10 \\
(0.04)\end{array}$ & $0.59^{* * *}$ & $\begin{array}{l}2.72 \\
(0.04)\end{array}$ & $\begin{array}{l}2.11 \\
(0.04)\end{array}$ & $0.61^{* * *}$ & $\begin{array}{c}2.93 \\
(0.03)\end{array}$ & $\begin{array}{c}2.21 \\
(0.01)\end{array}$ & $0.72^{s s s}$ \\
\hline & 2010-2015 & $\begin{array}{c}2.45 \\
(0.09)\end{array}$ & $\begin{array}{l}2.24 \\
(0.07)\end{array}$ & 0.21 & $\begin{array}{c}2.80 \\
(0.06)\end{array}$ & $\begin{array}{l}2.24 \\
(0.05)\end{array}$ & $0.55^{* * 8}$ & $\begin{array}{c}2.82 \\
(0.05)\end{array}$ & $\begin{array}{c}2.33 \\
(0.05)\end{array}$ & $0.49^{* * *}$ & $\begin{array}{c}3.04 \\
(0.04)\end{array}$ & $\begin{array}{c}2.36 \\
(0.01)\end{array}$ & $0.68^{2 s s}$ \\
\hline \multirow[t]{5}{*}{ Immigration rate $(\%)$} & 1971-1979 & $\begin{array}{c}2.72 \\
(0.12)\end{array}$ & $\begin{array}{c}1.69 \\
(0.07)\end{array}$ & $1.03^{* * *}$ & $\begin{array}{l}2.53 \\
(0.07)\end{array}$ & $\begin{array}{c}1.95 \\
(0.05)\end{array}$ & $0.58^{* * *}$ & $\begin{array}{c}2.71 \\
(0.06)\end{array}$ & $\begin{array}{c}2.00 \\
(0.05)\end{array}$ & $0.71^{* * *}$ & $\begin{array}{c}3.08 \\
(0.04)\end{array}$ & $\begin{array}{c}2.18 \\
(0.02)\end{array}$ & $0.90^{s s z}$ \\
\hline & 1980-1989 & $\begin{array}{r}2.44 \\
(0.11)\end{array}$ & $\begin{array}{l}2.17 \\
(0.09)\end{array}$ & 0.26 & $\begin{array}{l}2.41 \\
(0.06)\end{array}$ & $\begin{array}{l}2.12 \\
(0.05)\end{array}$ & $0.29^{* * *}$ & $\begin{array}{r}2.51 \\
(0.06)\end{array}$ & $\begin{array}{l}2.17 \\
(0.05)\end{array}$ & $0.34^{* * *}$ & $\begin{array}{r}2.89 \\
(0.04)\end{array}$ & $\begin{array}{l}2.21 \\
(0.02)\end{array}$ & $0.68^{s s s}$ \\
\hline & 1990-1999 & $\begin{array}{c}2.39 \\
(0.10)\end{array}$ & $\begin{array}{c}2.29 \\
(0.08)\end{array}$ & 0.11 & $\begin{array}{l}2.64 \\
(0.06)\end{array}$ & $\begin{array}{l}2.36 \\
(0.05)\end{array}$ & $0.28^{* * z}$ & $\begin{array}{l}2.68 \\
(0.05)\end{array}$ & $\begin{array}{l}2.45 \\
(0.05)\end{array}$ & $0.24^{* *}$ & $\begin{array}{l}2.98 \\
(0.04)\end{array}$ & $\begin{array}{c}2.31 \\
(0.01)\end{array}$ & $0.67^{5 s 8}$ \\
\hline & 2000-2009 & $\begin{array}{c}3.04 \\
(0.10)\end{array}$ & $\begin{array}{l}2.64 \\
(0.08)\end{array}$ & $0.40^{* *}$ & $\begin{array}{c}3.27 \\
(0.06)\end{array}$ & $\begin{array}{c}2.63 \\
(0.05)\end{array}$ & $0.63^{* * *}$ & $\begin{array}{c}3.25 \\
(0.05)\end{array}$ & $\begin{array}{c}2.74 \\
(0.05)\end{array}$ & $0.51^{* * *}$ & $\begin{array}{c}3.35 \\
(0.04)\end{array}$ & $\begin{array}{c}2.81 \\
(0.02)\end{array}$ & $0.54^{s s s}$ \\
\hline & 2010-2015 & $\begin{array}{c}3.10 \\
(0.12)\end{array}$ & $\begin{array}{c}2.51 \\
(0.11)\end{array}$ & $0.59^{* * *}$ & $\begin{array}{c}3.40 \\
(0.07)\end{array}$ & $\begin{array}{l}2.67 \\
(0.07)\end{array}$ & $0.73^{* * *}$ & $\begin{array}{c}3.35 \\
(0.07)\end{array}$ & $\begin{array}{l}2.65 \\
(0.06)\end{array}$ & $0.70^{* * *}$ & $\begin{array}{c}3.33 \\
(0.04)\end{array}$ & $\begin{array}{c}2.79 \\
(0.02)\end{array}$ & $0.55^{s s s}$ \\
\hline \multirow[t]{5}{*}{ Net immigration rate (\%) } & 1971-1979 & $\begin{array}{c}-1.37 \\
(0.14)\end{array}$ & $\begin{array}{c}-1.40 \\
(0.10)\end{array}$ & 0.03 & $\begin{array}{c}-1.90 \\
(0.08)\end{array}$ & $\begin{array}{c}-1.16 \\
(0.07)\end{array}$ & $-0.75^{* * *}$ & $\begin{array}{c}-1.78 \\
(0.07)\end{array}$ & $\begin{array}{c}-0.95 \\
(0.06)\end{array}$ & $-0.83^{* * * *}$ & $\begin{array}{c}-1.68 \\
(0.05)\end{array}$ & $\begin{array}{c}-0.97 \\
(0.02)\end{array}$ & $-0.71^{s s 8}$ \\
\hline & 1980-1989 & $\begin{array}{c}-0.91 \\
(0.12)\end{array}$ & $\begin{array}{c}-0.72 \\
(0.10)\end{array}$ & -0.19 & $\begin{array}{c}-1.11 \\
(0.08)\end{array}$ & $\begin{array}{c}-0.59 \\
(0.06)\end{array}$ & $-0.52^{* * *}$ & $\begin{array}{c}-1.10 \\
(0.07)\end{array}$ & $\begin{array}{c}-0.48 \\
(0.06)\end{array}$ & $-0.62^{* * * *}$ & $\begin{array}{c}-1.23 \\
(0.05)\end{array}$ & $\begin{array}{c}-0.58 \\
(0.02)\end{array}$ & $-0.65^{5 * 8}$ \\
\hline & 1990-1999 & $\begin{array}{c}-0.39 \\
(0.12)\end{array}$ & $\begin{array}{c}0.08 \\
(0.10)\end{array}$ & $-0.47^{* *}$ & $\begin{array}{c}-0.13 \\
(0.07)\end{array}$ & $\begin{array}{c}0.10 \\
(0.06)\end{array}$ & $-0.23^{*}$ & $\begin{array}{c}-0.12 \\
(0.06)\end{array}$ & $\begin{array}{c}0.15 \\
(0.06)\end{array}$ & $-0.27^{* *}$ & $\begin{array}{c}-0.01 \\
(0.04)\end{array}$ & $\begin{array}{c}0.02 \\
(0.02)\end{array}$ & -0.03 \\
\hline & $2000-2009$ & $\begin{array}{c}0.45 \\
(0.11)\end{array}$ & $\begin{array}{c}0.56 \\
(0.09)\end{array}$ & -0.10 & $\begin{array}{c}0.58 \\
(0.07)\end{array}$ & $\begin{array}{c}0.53 \\
(0.06)\end{array}$ & 0.05 & $\begin{array}{c}0.53 \\
(0.06)\end{array}$ & $\begin{array}{c}0.62 \\
(0.06)\end{array}$ & -0.09 & $\begin{array}{c}0.42 \\
(0.04)\end{array}$ & $\begin{array}{c}0.60 \\
(0.02)\end{array}$ & $-0.18^{2 s z}$ \\
\hline & 2010-2015 & $\begin{array}{c}0.65 \\
(0.14)\end{array}$ & $\begin{array}{c}0.28 \\
(0.12)\end{array}$ & $0.38^{*}$ & $\begin{array}{c}0.60 \\
(0.08)\end{array}$ & $\begin{array}{c}0.43 \\
(0.07)\end{array}$ & 0.18 & $\begin{array}{c}0.53 \\
(0.07)\end{array}$ & $\begin{array}{c}0.31 \\
(0.07)\end{array}$ & $0.21^{*}$ & $\begin{array}{c}0.29 \\
(0.05)\end{array}$ & $\begin{array}{c}0.42 \\
(0.02)\end{array}$ & $-0.13^{*}$ \\
\hline
\end{tabular}

Note: Columns (1), (2), (4), (5), (7), (8), (10), and (11) contain means and standard errors (in parentheses). Columns (3), (6), (9), and (12) contain differences in means with ${ }^{\dagger}=p<0.1,{ }^{*} *=p<0.05,{ }^{*} * *=p<0.01,{ }^{*} * *=p<0.001$. 
Table A.5: Descriptive statistics for turnout in municipal elections

\begin{tabular}{ccccc}
\hline \multirow{2}{*}{ Elections } & \multicolumn{3}{c}{ Settlements } & \multirow{2}{*}{$\begin{array}{c}\text { Difference } \\
\end{array}$} \\
\cline { 2 - 4 } & All & New & Old & $(2)-(3)$ \\
\cline { 2 - 4 } & $(1)$ & $(2)$ & $(3)$ & $(4)$ \\
\hline \multirow{2}{*}{1990} & 85.72 & 78.22 & 87.59 & $-9.37^{* * *}$ \\
& $(0.14)$ & $(0.36)$ & $(0.15)$ & \\
1994 & 78.18 & 70.05 & 80.36 & $-10.31^{* * *}$ \\
& $(0.13)$ & $(0.40)$ & $(0.13)$ & \\
1998 & 67.37 & 61.13 & 69.36 & $-8.23^{* * *}$ \\
& $(0.17)$ & $(0.50)$ & $(0.18)$ & \\
2002 & 66.17 & 62.44 & 67.59 & $-5.14^{* * *}$ \\
& $(0.16)$ & $(0.46)$ & $(0.17)$ & \\
2006 & 63.27 & 59.93 & 64.53 & $-4.59^{* * *}$ \\
& $(0.16)$ & $(0.48)$ & $(0.17)$ & \\
2010 & 63.41 & 61.34 & 64.42 & $-3.08^{* * *}$ \\
& $(0.15)$ & $(0.46)$ & $(0.17)$ & \\
2014 & 60.62 & 58.37 & 61.65 & $-3.27^{* * *}$ \\
& $(0.16)$ & $(0.47)$ & $(0.17)$ & \\
\hline
\end{tabular}

Note: Columns (1) to (3) contain means and standard errors (in parentheses). Columns (4) contains difference in means with ${ }^{\dagger}=p<0.1,{ }^{*} *=p<0.05,{ }^{*} * *=p<0.01,{ }^{*} * *=p<0.001$. 


\section{References}

Školl, Jaroslav. 1983. Nové osídlení okresu Břeclav po roce 1945. Mikulov: Okresní archív Břeclav. 


\section{B Appendix: Description of data set and merging definitions of communities}

\section{B.1 Migration data}

Data on permanent residence changes within a year was obtained from the website of the Czech Statistical Office (CZSO, https://www.czso.cz/csu/czso/databaze-demografickychudaju-za-obce-cr, last accessed April $4^{\text {th }}$ 2019). These data are compiled from administrative historical records on annual residence changes from 1971 to 2015 by the CZSO. Issues related to changing definitions of borders and territories of settlements are not applicable as CZSO matches them to a consistent data set throughout. The data report the number of people who move in and out of a settlement per year and provide information on the population of a settlement on January $1^{\text {st }}$ of a year. The latter are imputed by CZSO using the last census and annual migration, mortality and natality statistics. The emigration and immigration rates as well as the net immigration rates are used as dependent variables and are defined as the number of residential moves across settlement borders over a year in percent of the population on January $1^{\text {st }}$ of the year.

The data are not a balanced panel because some records were lost prior to their digitization. The number of missing observations is highest in the late 1980s. In this period observations on only $66 \%$ of the settlements are available. Data availability swiftly improves after the fall of the communist regime in 1989. As of the year $199296.7 \%$ of the data are observed and this ratio has grown ever since. Throughout the main part of the paper we use the maximum number of observations possible and thus focus on unbalanced panel data. We address issues relating to missing observations in additional robustness checks, where we present results based on a balanced panel (see Appendix C).

Furthermore, in processing the data we remove outliers by removing the top $1 \%$ of observations with respect to emigration and immigration rates that may be due to large region-specific shocks (such as e.g. the destruction of a number of settlements due to open pit lignite mining in the Northwest of the Czech Republic - see Vaněk 1996). In our robustness checks in Appendix $\mathrm{C}$ we show that this has only minor impacts on the estimated causal effects and if anything increases them. This implies that by omitting outliers, estimates are more conservative.

\section{B.2 Census Data}

The key source of historical demographic data of settlements is the publicly available database "Historický lexikon obcí" (available at ast accessed April $4^{\text {th }} 2019$ ). The database 
is compiled and maintained by the CZSO. It contains settlement level data from general censuses on the total population going back to 1869 using the definition of settlements in 2011. This data is our source of information on the population and the number of houses in a settlement in 1930 .

Unfortunately, data on the ethnic Germans in a settlement, which was contained in the 1930 census and is based on a question on the language spoken in the household was, not digitized. We therefore inputted this data from the printed statistical overviews of the 1930 census published in the 1930s for the 11,797 settlements reported in the 1930 census. These settlements do not accord with the definition of the 6,258 settlements in 2011, that are the observational units for all other data. To derive consistent data we therefore applied the same aggregation rules as used by the CZSO in the construction of time series for the "Historický lexikon obcí" and aggregated pre-WWII data to the 2011 settlements. ${ }^{23}$ Using these aggregation rules we succeeded in matching 6168 settlements $(98.6 \%)$ with their 1930 counterparts. 4,210 of these settlements were matched 1 to 1 , and 865 settlements were matched 2 to 1 . Only 307 current settlements consist of more than five 1930 settlements with the maximum number of settlements being found in today's Prague, the country capital, which consisted of 60 historical settlements in 1930.

In our robustness checks we also use data from the decennial population censuses held since 1980. These are the only source on the age and highest completed education of the population of the settlements. The post-WWII general censuses were held in 1950, 1961, 1970, 1980, 1991, 2001, and 2011. Data on the age and education structure at settlement level are available only for 1980 onward because non-digitized records from the previous censuses were lost to a flood in 2002. We therefore obtained the 2011 census data at the CZSO website (https://www.czso.cz/csu/czso/otevrena_data_pro_vysledky_scitani_lidu_ domu_a_bytu_2011_sldb_2011, last accessed April 4 ${ }^{\text {th }}$ 2019), while data from the 1980, 1991 and 2001 censuses aggregated on the level of 2011 settlements were provided to us by the CZSO upon request.

\section{B.3 Data on election turnout}

Data on election turnout for all municipal elections from 2006 to 2014, was downloaded from the official website for election results run by CZSO (https://www.volby.cz/opendata/ opendata.htm), last accessed April $4^{\text {th }} 2019$ ). For earlier elections the data were provided by CZSO upon request. These data contain the number of eligible voters as well as the

23. The necessary aggregation rules were kindly provided by the CZSO. They are based on tracking individual neighborhoods. For example, if a settlement was divided and merged with multiple settlements the aggregation rules associate the historical records of the settlement with a settlement which absorbed the largest neighborhood. By applying these rules the CZSO can construct long-term time-series on population for current settlements. 
number of ballots cast in all the free municipal elections with voluntary voting held in today's Czech Republic since 1990 for each settlement. They can therefore be used to calculate turnout rates. These are defined as the share of votes cast in percent of the eligible voters for each election. This measure is highly reliable, as voting outside the community in which voters are registered as residents is not possible in municipal elections in the Czech Republic.

\section{B.4 Data on the resettlement of Břeclav area}

There is no comprehensive data set available on the resettlement process due to its often chaotic nature. To our knowledge the study by Školl (1983)) on the resettlement of the Břeclav area, South Moravia, is the only data source covering a compact region. This study presents data on the resettlement collected from two principal sources: individual 1950 census questionnaires, and records on the land redistribution. Školl's study contains basic information on origins of settlers. For the settlers from today's Czech Republic he lists individual settlements of the origin while for settlers from Slovakia and foreign countries the study contains only districts or country of origin. The presented data sometimes report only information on the number of families that moved and sometimes only the number of persons, while in some instances ( $12 \%$ of all cases) it contains both families and persons. We use these overlaps to impute the number of persons moving based on the average family size (3.8 individuals) to estimate the number of moving persons for all records where this information is missing in the original data.

\section{B.5 Survey data on social capital}

The paper also uses two surveys on the social values and social capital in the Czech Republic. While several surveys in the Czech Republic include questions on local social capital and various values, to the best of our knowledge, only these two provide geolocated respondents at a settlement level and thus allow to determine whether respondents lived in new or old settlements.

\section{B.5.1 Survey “Český venkov 2004: život mladých a starých lidî”}

Data on social values is taken from the survey "Český venkov 2004: život mladých a starých lidî” (Majerová et al. 2004), which was conducted among young (aged 18-29) and old (aged 60-74) respondents in small settlements (with less than 2000 inhabitants) in 2004 using a standardized questionnaire. Data are available from the Czech Social Science Data Archive (http://archiv.soc.cas.cz/en, last accessed April $4^{\text {th }}$ 2019). They contain observations on 751 young respondents and on 767 old respondents. 
We exclude respondents living in settlements with a population in excess of 2,000 inhabitants according to the 2001 census ( 12 young respondents and 7 old respondents) and with a self-reported age outside the range declared by the survey definition (4 young respondents older than 29 and 17 old respondents younger than 60) from the sample. This leaves us with 735 young and 738 old respondents. Young respondents are drawn from 275 and old respondents from 278 different settlements. The geographical distribution of the settlements and settlement types covered are reported in Figure B.1.

The questions we use asked respondents on their on their values. These were elicited through the battery of questions listed in Table B.1. As respondents evaluated all listed values independently the answers tend to be strongly skewed towards positive evaluations (i.e. "Very important" and "Rather important") with "Very important" being chosen in $51 \%$ cases by young and in $52 \%$ by the old group (see Figure B.2). The importance of spiritual values is the only significant exception from the pattern as only $7 \%$ of young respondents consider them being "Very important" (see Table 7). Therefore, in the main part of the paper these variables are encoded as an indicator variable that takes on a value of 1 if a respondent answered a question with "Very important" and zero else. We, however, conducted robustness checks with linear regressions using the full set of values for responses. These robustness checks suggest that our choice of coding has few consequences for the qualitative results (see Appendix C below). 
Table B.1: Questions used from survey "Český venkov 2004: život mladých a starých lidí"

\begin{tabular}{|c|c|}
\hline \multicolumn{2}{|c|}{ Wording of the question } \\
\hline English & Czech (original) \\
\hline $\begin{array}{l}\text { In the following questions, we will focus on your } \\
\text { personal values and goals. }\end{array}$ & $\begin{array}{l}\text { V následujicích otázkách se zaměřime na Vaše } \\
\text { životní hodnoty a cíle. }\end{array}$ \\
\hline $\begin{array}{l}\text { People in their lives value some things more and } \\
\text { some things less. How important are following } \\
\text { things in your life? Please, assign to each } \\
\text { of listed values an importance for your life } \\
\text { nowadays. Please, try to use the whole scale } \\
\text { from } 1 \text { to } 4 \text { from the CARD while evaluating. }\end{array}$ & $\begin{array}{l}\text { Lidé si ve svém životě některých věcí cení více, } \\
\text { některých méně. Jak důležité jsou následujicí } \\
\text { věci pro Váš osobní život? Přiřadte prosím } \\
\text { každé z vyjmenovaných hodnot důležitost, kterou } \\
\text { jim ve svém současném životě přikládáte. Při } \\
\text { hodnocení podle KARTY se, prosím, snažte } \\
\text { využivat celou stupnici od jednička do čtyřky. }\end{array}$ \\
\hline CARD: & KARTA: \\
\hline 1. Very important & 1. Velmi důležité \\
\hline 2. Rather important & 2. Spíše důležité \\
\hline 3. Rather unimportant & 3. Spíše nedůležité \\
\hline 4. Not important at all & 4. Zcela nedi̊ležité \\
\hline VALUES: & HODNOTY: \\
\hline 1. Nature, environment & 1. Příroda, životní prostředí \\
\hline 2. Job, occupation & 2. Práce, zaměstnání \\
\hline 3. Relationships & 3. Mezilidské vztahy \\
\hline 4. Faith, spiritual values & 4. Víra, duchovní hodnoty \\
\hline 5. Interests, hobbies & 5. Zájmy, koníčky \\
\hline 6. Housing & 6. Bydlení \\
\hline 7. Friendship & 7. Přátelství, parta \\
\hline 8. Health status & 8. Zdravotní stav \\
\hline 9. Family life, children & 9. Rodinný život, děti \\
\hline 10. Material conditions & 10. Materiální podmínky \\
\hline
\end{tabular}

Source: "Český venkov 2004: ̌̌ivot mladých a starých lidí" (Majerová et al. 2004) 
Figure B.1: Location of respondents by settlement type in "Český venkov 2004: život mladých a starých lidí"
(a) Young respondents

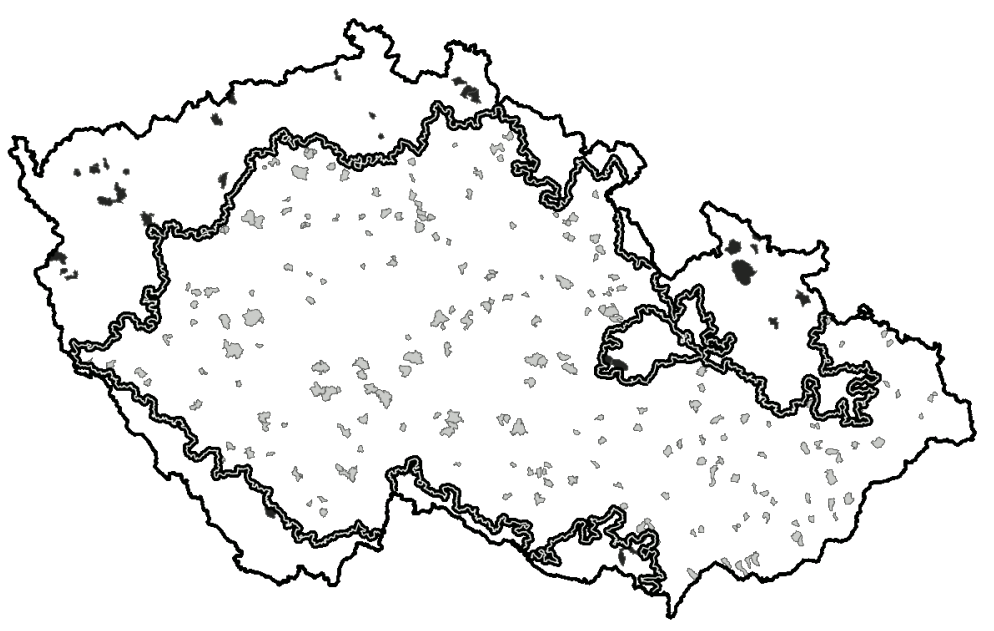

Share of ethnic

Germans (\%)

(b) Old respondents

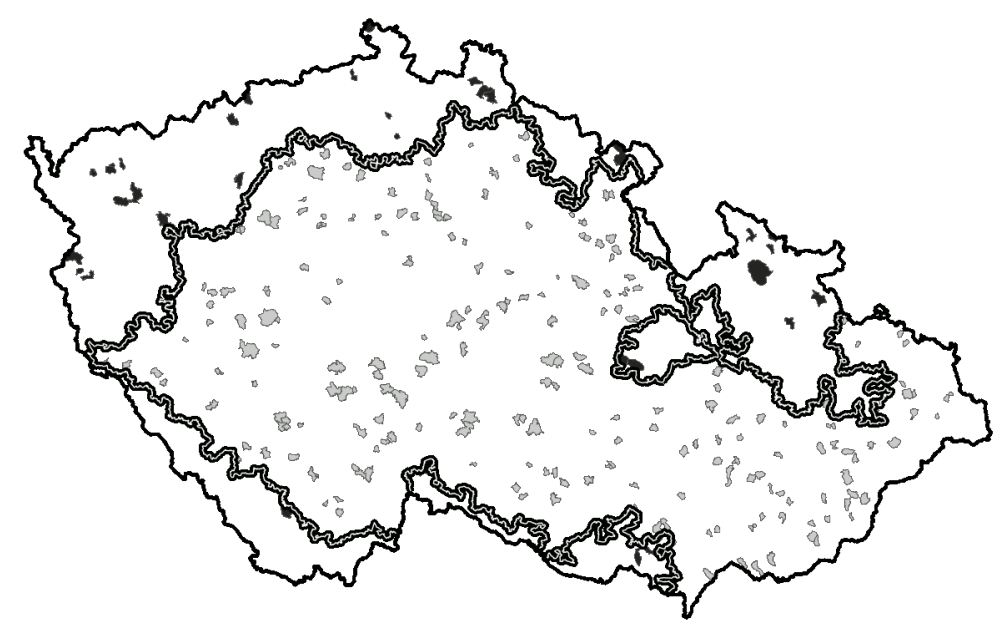

Share of ethnic

Germans (\%)

$(90,100]$ New settlements

$[0,10]$ Old settlements

Ethnic border

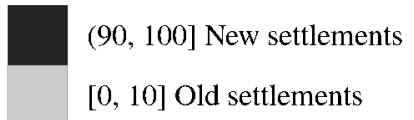

Source: "Český venkov 2004: život mladých a starých lidí" (Majerová et al. 2004), own calculations 
Figure B.2: Distribution of the responses to value questions in "Český venkov 2004: život mladých a starých lidí"

(a) Young respondents

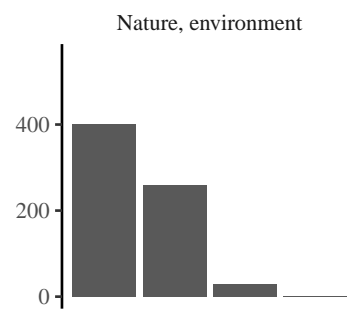

Relationships

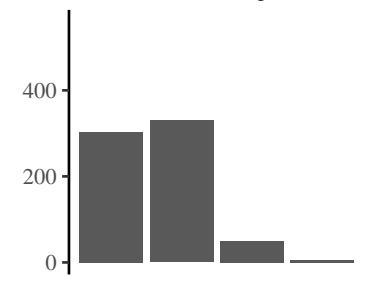

Hobbies

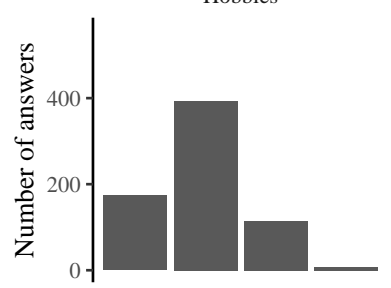

Friendship

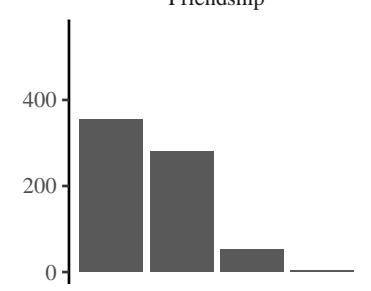

Family life and children

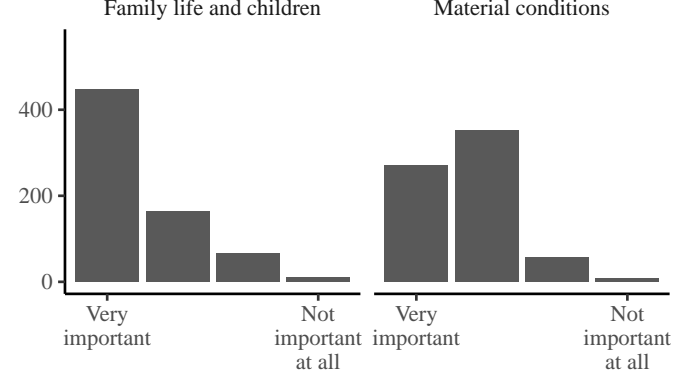

(b) Old respondents

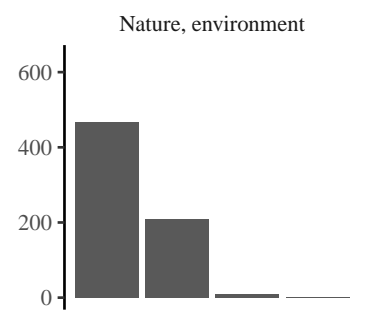

Relationships

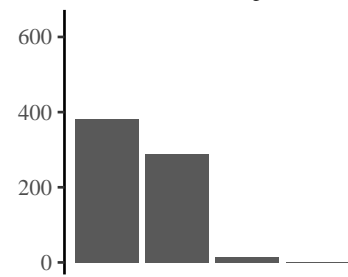

Hobbies

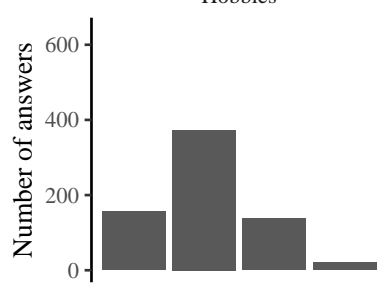

Friendship
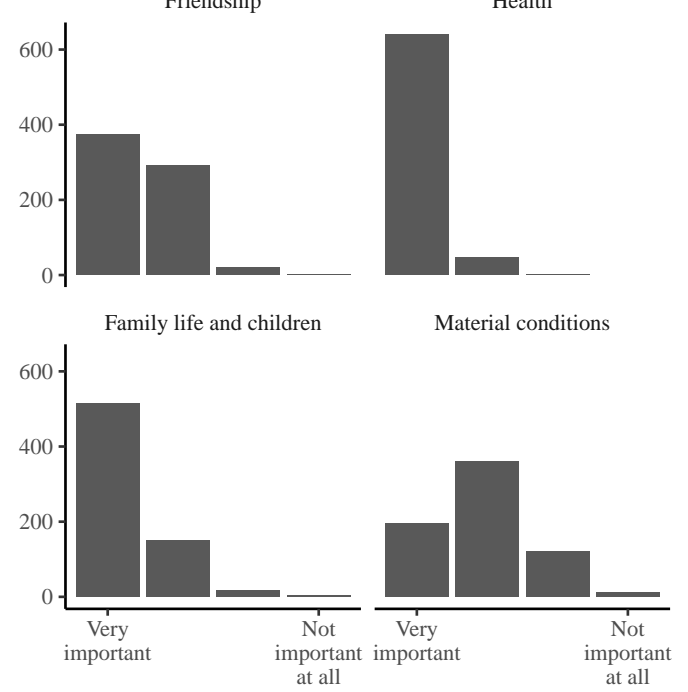

Source: "Český venkov 2004: život mladých a starých lidí" (Majerová et al. 2004), own calculations 


\section{B.5.2 Survey “Český venkov 2003: situace před vstupem do EU”}

The second survey used is the survey "Český venkov 2003: situace pred vstupem do EU" (Majerová et al. 2003). It too was conducted in settlements with less than 2,000 inhabitants in 2003. In its first wave this survey asked mayors of settlements on the number of events organized by local clubs and green activities in their settlement, while in the second wave individuals were asked on whether they are member of a club, participated in an event, have made donation or have committed to conduct voluntary work. We use this survey to evaluate the stock of local social capital in the settlements of the Czech Republic. Data from both waves of the survey can be downloaded from the Czech Social Science Data Archive (http://archiv.soc.cas.cz/en, last accessed April $4^{\text {th }}$ 2019).

The first wave was a correspondence expert opinion survey. In this 2,000 mayors of small settlements (with up to 2000 inhabitants) were asked to assess various characteristics of their settlement. 1,324 (66\%) of the mayors participated. From these we exclude 37 settlements with a population above the declared threshold of 2,000 inhabitants according to the 2001 population census. This leaves us with 1,287 usable observations (see top panel of Figure B.3 for their spatial distribution and settlement types).

We focus on two questions asked in this first wave. The first is the reported number of events organized by local clubs; the second is the number of "green activities". For the number of events, mayors were asked to report the number of events organized by rather broad categories of clubs: Voluntary firefighters, sport clubs, hunters, breeders, Red cross, women union, and others. The survey used the following question:

“Označte spolky a zájmová sdružení, které aktivně působí ve Vaši obci a napište počet akcí, které daný spolek pořádal pro veřejnost za poslední rok."

"Choose clubs and voluntary organizations, which are active in your village and fill in the number of public events the club organized in the last year."

We use the reported number of events as a dependent variable.

For "green activities" - i.e. collective activities aimed to improve the environment and living conditions in the settlement (e.g. "spring cleaning", football field reconstruction, etc.) with the participation of locals - mayors were asked:

"Pořádají se u Vás akce pro zvelebování obce, kterých se účastní obyvatelé obce?"

"Are there green activities in your village, which locals participate in?"

If respondents answered this question affirmatively they were also required to list the number of events held. We used this number as the dependent variable in the estimates. 
Figure B.3: Location of respondents by settlement type in "Český venkov 2003: situace před vstupem do EU"

(a) First Wave (mayors)

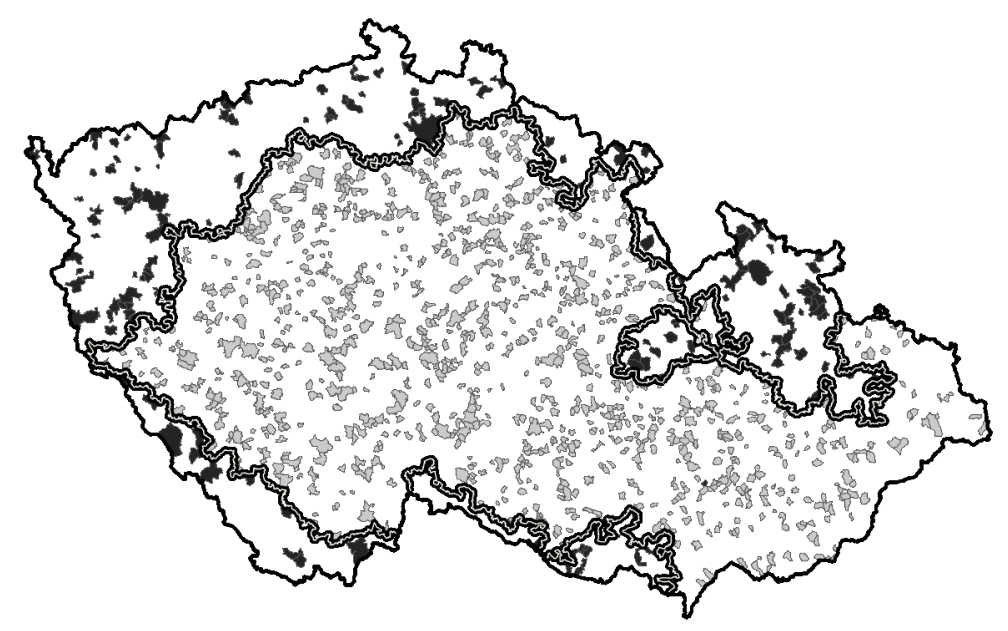

Share of ethnic

Germans (\%)

(b) Second Wave (residents)

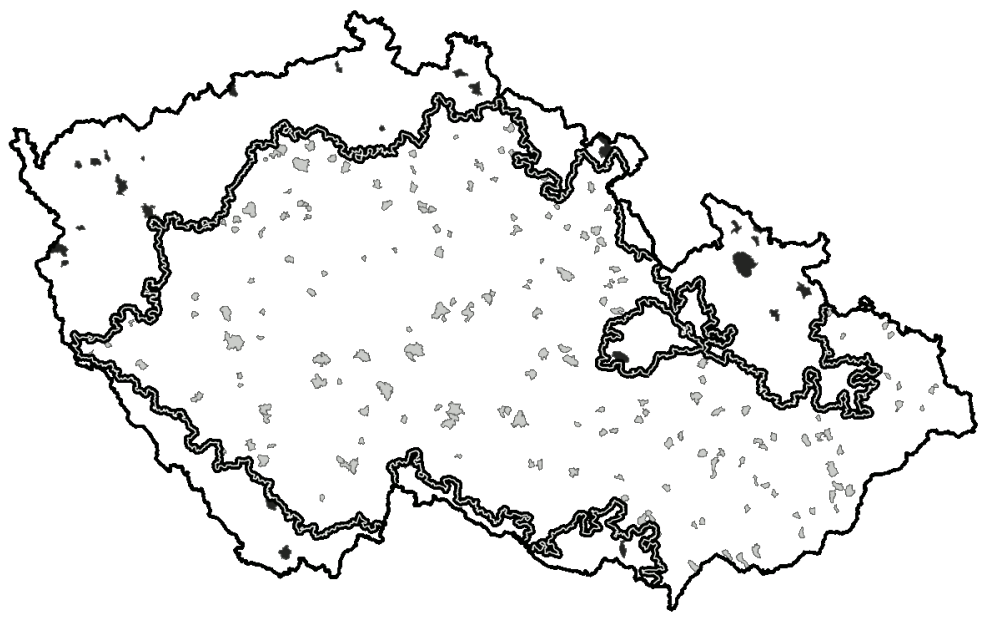

Share of ethnic

Germans $(\%)$

$[0,10]$ Old settlements

Ethnic border

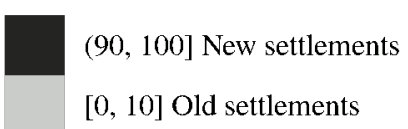

Source: "Český venkov 2003: situace před vstupem do EU" (Majerová et al. 2003), own calculations 
The second wave of the survey focused on individuals living in a selection of small settlements in the Czech Republic. Interviews were conducted among 1,634 respondents. We exclude 27 respondents from settlements with a population above the declared threshold (of 2,000) in the 2001 census. This leaves us with 1,617 observations living in 223 different settlements (see bottom panel of Figure B.3 for their spatial distribution and settlements).

The first question we use, addresses the "use" of voluntary organizations and explicitly focuses on the settlement of residence by the respondent and members of his/her household:

"Využíváte vy nebo jiní členové domácnosti - spolky, zájmová sdružení v obci?"

"Do you, or any member of your household, use clubs or voluntary organizations in your village?"

The response to this question could be "Yes" or "No". The verb "využívat" (to use) in the original Czech wording of the question is not commonly used in this context. We interpret it as a broader term covering not only a membership but also not binding interactions - such as playing football on a club field without being an organized club member. It, therefore, addresses the nature of social capital as it captures interactions with fellow villagers. We encoded positive responses with a value of 1 and negative ones with a value of zero.

The other questions used, by contrast, focus on general charitable and social activities not necessarily related to the settlement of residence. They aim at eliciting information on general activities such as social events attendance, donation on charitable activities and volunteering. In addition, the question on volunteering explicitly asks respondents to take into account activities outside the settlement of residence. The wording of these questions is the following:

"Využíváte vy nebo jiní členové domácnosti - společenské akce (disco, plesy, zábavy)?”

"Do you, or any member of your household, attend social events (festivals, balls, etc.)?"

"Zapojil(a) jste se v roce 2002 jako dobrovolník do nějaké akce (nejen v obci)?”

“Did you volunteer for an event in 2002 (not only in your village)?”

"Poskytl(a) jste v roce 2002 dar na dobročinné účely?"

"Did you make a donation on charitable activities in 2002?"

The first two questions could be answered by "Yes" or "No" only and were thus encoded by an indicator variable that takes on the value of 1 for positive and zero for negative 
responses. The last question could be answered by "Yes, in kind and money", "Yes, in kind", "Yes in money" and "No". Here we encoded all positive responses (irrespective of whether they were in kind, in money or both) with one and a negative response with zero.

\section{B.5.3 Representativity of Questionnaires}

These questionnaires focus on a rather specific sample of settlements (settlements with 2,000 or less inhabitants). This raises obvious concerns about the representativity of this questionnaire. While we have no way to deal with this issue, we checked on the distribution of settlement size in 2001 among our matched settlements, the settlements in the proximity of the ethnic border, and our overall sample. This check suggests that settlements with 2,000 inhabitants or less account for $90 \%$ of the settlements in the Czech Republic and host $26 \%$ of the population. Similarly, such settlements account for $98 \%$ of the matched settlements in the Version 3 of the matching estimates and $90 \%$ of their population. Furthermore small settlements account for $92 \%$ of the new and old settlements within 15 kilometers band around the ethnic border used in RD estimates and $45 \%$ of the population of these settlements. Thus, while clearly not representative of the Czech Republic, the Sudetenland or the matched population, the data is at least representative of a large share of the affected area. 


\section{References}

Majerová, Věra, et al. 2003. Český venkov 2003, Situace před vstupem do EU. Prague: PEF CZU Praha.

—. 2004. Český venkov 2004, Život mladých a starých lidí. Prague: PEF CZU Praha.

Školl, Jaroslav. 1983. Nové osídlení okresu Břeclav po roce 1945. Mikulov: Okresní archív Břeclav.

Vaněk, Miroslav. 1996. Nedalo se tady dýchat: Ekologie v českých zemích v letech 1968 až 1989. Praha: Ústav pro soudobé dějiny AV ČR. 


\section{Appendix: Robustness tests}

We present results of robustness tests presented in Table 5 and an additional robustness test for regressions in Table 7.

1. We use the 1950 population as a matching and control variable.

2. We conduct the RD analysis and define treated settlements as settlements with a share of ethnic Germans of $50 \%$ or more and all others as a control group.

3. We check that the results are not due to historical institutional differences arising from the times when the Sudetenland belonged to German Reich (i.e., from 1938 to 1945) by focusing only on matches where both old and new settlements were located in the German Reich

4. We exclude the settlements located in the northeast of the Czech Republic characterized by a large number of ethnic border irregularities.

5. We use a balanced panel dataset.

6. We include outliers omitted in the previous analysis.

7. We Estimate linear regressions of the social value data with this encoded on a scale from 1 to 4 to ensure that our change of coding has no effects on results

\section{C.1 Robustness test 1: The 1950 population as a matching and control variable}

In the baseline specification we use 1930 population for matching and population fixed effects in RD estimates. The 1930 population is clearly exogenous to the resettlement process, but it may be a bad proxy for the development infrastructure and other man-made amenities as settlement sizes of former German settlements changed substantially between 1930 and the post-resettlement period. To address this concern we re-estimate matching and RD analysis using 1950 population as a matching variable and for population fixed effects specification.

In the matching estimates (Table C.1), coefficients for emigration and immigration as well as net immigration rates change by less than 0.1 percentage points throughout and also maintain their significance levels. Similarly, in the RD analysis (Table C.1) coefficients change by less than 0.1 relative to the baseline results reported in the main part of the paper. 
Table C.1: Robustness test 1: The 1950 population as a matching and control variable

\begin{tabular}{|c|c|c|c|c|c|c|}
\hline & \multicolumn{6}{|c|}{ Identification strategy } \\
\hline & \multicolumn{3}{|c|}{ Matching strategy } & \multicolumn{3}{|c|}{ RD strategy } \\
\hline & \multicolumn{3}{|c|}{ Matching version } & \multicolumn{3}{|c|}{ RD polynomial } \\
\hline & Version 1 & Version 2 & Version 3 & $1^{\text {st }}$ order & $2^{\text {nd }}$ order & $3^{\text {rd }}$ order \\
\hline & (1) & (2) & (3) & (4) & (5) & (6) \\
\hline & \multicolumn{6}{|c|}{$\begin{array}{l}\text { Dependent variable: } \\
\text { Emigration rate }(\%)\end{array}$} \\
\hline New settlement $(=1)$ & $\begin{array}{l}0.609^{* * *} \\
(0.073)\end{array}$ & $\begin{array}{l}0.711^{* * *} \\
(0.046)\end{array}$ & $\begin{array}{l}0.758^{* * *} \\
(0.042)\end{array}$ & $\begin{array}{l}0.712^{* * *} \\
(0.062)\end{array}$ & $\begin{array}{l}0.692^{* * *} \\
(0.090)\end{array}$ & $\begin{array}{l}0.600^{* * *} \\
(0.130)\end{array}$ \\
\hline Adjusted R2 & 0.207 & 0.234 & 0.231 & 0.169 & 0.169 & 0.169 \\
\hline Observations & 3,690 & 13,094 & 14,682 & 82,388 & 82,388 & 82,388 \\
\hline & \multicolumn{6}{|c|}{$\begin{array}{l}\text { Dependent variable: } \\
\text { Immigration rate }(\%)\end{array}$} \\
\hline New settlement $(=1)$ & $\begin{array}{l}0.480^{* * *} \\
(0.076)\end{array}$ & $\begin{array}{l}0.451^{* * *} \\
(0.063)\end{array}$ & $\begin{array}{l}0.509^{* * *} \\
(0.047)\end{array}$ & $\begin{array}{l}0.549^{* * *} \\
(0.071)\end{array}$ & $\begin{array}{l}0.482^{* * *} \\
(0.103)\end{array}$ & $\begin{array}{l}0.420^{* *} \\
(0.148)\end{array}$ \\
\hline Adjusted R2 & 0.109 & 0.131 & 0.127 & 0.088 & 0.088 & 0.088 \\
\hline \multirow[t]{2}{*}{ Observations } & 3,690 & 13,094 & 14,682 & 82,388 & 82,388 & 82,388 \\
\hline & \multicolumn{6}{|c|}{$\begin{array}{c}\text { Dependent variable: } \\
\text { Net immigration rate }(\%)\end{array}$} \\
\hline New settlement $(=1)$ & $\begin{array}{c}-0.129^{* *} \\
(0.047)\end{array}$ & $\begin{array}{l}-0.260^{* * *} \\
(0.063)\end{array}$ & $\begin{array}{l}-0.249^{* * *} \\
(0.044)\end{array}$ & $\begin{array}{c}-0.163^{* *} \\
(0.062)\end{array}$ & $\begin{array}{r}-0.210^{*} \\
(0.090)\end{array}$ & $\begin{array}{l}-0.180 \\
(0.126)\end{array}$ \\
\hline Adjusted R2 & 0.119 & 0.138 & 0.131 & 0.097 & 0.097 & 0.097 \\
\hline Observations & 3,690 & 13,094 & 14,682 & 82,388 & 82,388 & 82,388 \\
\hline
\end{tabular}

Note: Estimates from Equations (1) and (3) in the main text. Matching estimates: In Version 1 settlements are matched only if they are located less than $5 \mathrm{~km}$ from each other and their population difference is less than 500 inhabitants. In Versions 2 and 3 these maxima are $10 \mathrm{~km}$ and 250 inhabitants, and $10 \mathrm{~km}$ and 500 inhabitants, respectively. All estimates control for pair fixed effects, year fixed effects, log of altitude, terrain roughness, and log of the distance to the country border. RD strategy: Only settlements within a $15 \mathrm{~km}$ band around the ethnic border are considered. Results control for year fixed effects, an RD polynomial, and region fixed effects, population fixed effect, $\log$ of altitude, terrain roughness, and log of the distance to the country border. Symbols represent statistical significance of differences in means between old and new settlements with ${ }^{\dagger}=p<0.1,{ }^{*}=p<0.05,{ }^{* *}=p<0.01,{ }^{* * *}=p<0.001$. Values in brackets are clustered standard errors. 


\section{C.2 Robustness test 2: Focusing on all settlements in the RD analysis}

Another concern with the RD strategy is that we focus only on settlements which either had a $90 \%$ German speaking majority in the German part of the country or a $90 \%$ Czech speaking majority in the Czech speaking part of the country. This means we omit 466 (18\%) settlements from our data (see Figure 2 in the main part of the paper). This could imply that RD estimates may be influenced by a few outliers located directly at the border. To check on this issue, we added another robustness check where we define treated group as settlements with a majority (more than 50\%) of ethnic Germans and the rest of settlements as a control group. The disadvantage of this approach is that this may lead to a comparison of settlements at the border, that were only marginally differently affected by resettlement. The advantage is that now virtually all settlements in the 15 kilometer band around the ethnic border are included in the analysis.

The results of this robustness check (reported in Table C.2) once more indicate a high consistency with the results reported in the main part of the paper. According to the results the impact of resettlement on emigration and immigration rates as well as net immigration rates changes by less than 0.1 throughout. 
Table C.2: Robustness test 2: Focusing on all settlements in the RD analysis

\begin{tabular}{lccc}
\hline & \multicolumn{3}{c}{ Polynomial forcing function } \\
\cline { 2 - 4 } & $1^{\text {st }}$ order & $2^{\text {nd }}$ order & $3^{\text {rd }}$ order \\
\cline { 2 - 4 } & $(1)$ & $(2)$ & $(3)$ \\
\hline \multicolumn{4}{c}{ Dependent variable: } \\
New settlement $(=1)$ & $0.653^{* * *}$ & $0.542^{* * *}$ & $0.504^{* * *}$ \\
& $(0.043)$ & $(0.063)$ & $(0.089)$ \\
Adjusted R2 & 0.190 & 0.190 & 0.190 \\
Observations & 101,139 & 101,139 & 101,139 \\
& \multicolumn{3}{c}{ Dependent variable: } \\
New settlement $(=1)$ & $0.435^{* * *}$ & $0.359^{* * *}$ & $0.371^{* * *}$ \\
& $(0.049)$ & $(0.071)$ & $(0.101)$ \\
Adjusted R2 & 0.095 & 0.095 & 0.095 \\
Observations & 101,139 & 101,139 & 101,139 \\
& \multicolumn{3}{c}{ Dependent variable: } \\
Net & \multicolumn{4}{c}{ Immigration rate $(\%)$} \\
New settlement $(=1)$ & $-0.218^{* * *}$ & $-0.183^{* *}$ & -0.133 \\
Adjusted R2 & $(0.044)$ & $(0.065)$ & $(0.092)$ \\
Observations & 0.094 & 0.094 & 0.094 \\
& 101,139 & 101,139 & 101,139 \\
\hline
\end{tabular}

Note: Estimates from Equation (3) in the main text. Only settlements within a $15 \mathrm{~km}$ band around the ethnic border are considered. Results control for year fixed effects, an RD polynomial, and region fixed effects, population fixed effect, log of altitude, terrain roughness, and $\log$ of the distance to the country border. Symbols represent statistical significance of differences in means between old and new settlements with $\dagger=p<0.1,{ }^{*}=p<0.05,{ }^{* *}=p<0.01,{ }^{* * *}=p<0.001$. Values in brackets are clustered standard errors. 


\section{C.3 Robustness test 3: Impact of institutional differences}

To check whether results are related to historical differences that arose when the Sudetenland belonged to German Reich (i.e. from 1938 to 1945) rather than the subsequent resettlement we conducted matching estimates using only those matches where both old and new settlements were located in the German Reich from 1938 to $1945 .{ }^{24}$ In this way we ensure that the matched old and new settlements were both operating under the same institutional setting before, during and after WWII. ${ }^{25}$ These restrictions severely reduce the number of observations. Results (reported in Table C.3), however, indicate that emigration rates among the new settlements located in the German Reich from 1938 to 1945 were by in average 0.9 percentage points and immigration rates were by 0.6 percentage points higher than among the old settlements located in the German Reich from 1938 to 1945 . Net immigration also has a statistically significantly negative coefficient. This suggests that net immigration rates fell by -0.3 percentage points as a reaction to resettlement in the average of the years 1971 to 2015 .

Table C.3: Robustness test 3: Impact of institutional differences

\begin{tabular}{lccc}
\hline & \multicolumn{3}{c}{ Dependent variable } \\
\cline { 2 - 4 } & $\begin{array}{c}\text { Emigration } \\
\text { rate (\%) }\end{array}$ & $\begin{array}{c}\text { Immigration } \\
\text { rate (\%) }\end{array}$ & $\begin{array}{c}\text { Net } \\
\text { immigration } \\
\text { rate (\%) }\end{array}$ \\
\cline { 2 - 4 } & $(1)$ & $(2)$ & $(3)$ \\
\hline New settlement (=1) & $0.915^{* * *}$ & $0.529^{* * *}$ & $-0.386^{* * *}$ \\
Adjusted R2 & $(0.065)$ & $(0.084)$ & $(0.070)$ \\
Observations & 0.234 & 0.123 & 0.108 \\
\hline
\end{tabular}

Note: Estimates from Equation (1) in the main text. Settlements are matched only if they are located less than $10 \mathrm{~km}$ from each other and their population difference is less than 500 inhabitants. All estimates control for pair fixed effects, year fixed effects, log of altitude, terrain roughness, and log of the distance to the country border. Symbols represent statistical significance of differences in means between old and new settlements with ${ }^{\dagger}=p<0.1,{ }^{*}=p<0.05,{ }^{* *}=p<0.01,{ }^{* * *}=p<0.001$. Values in brackets are clustered standard errors.

24. This robustness check is based on Version 3 of the matching estimates, where city pairs are allowed to be at most 10 kilometers from each other and have a maximum difference in population of 500 persons.

25. The opposite option of using settlements that both remained under Czech rule is not open to us, as there are only very few such pairs of settlements. 


\section{C.4 Robustness test 4: Exclusion of a part of ethnic border characterized by a large number of irregularities}

One of the issues with using the RD strategy is that throughout history (with the exception of the time from 1938 to 1945) a well-defined border between the Czech and German parts of today's Czech Republic did not exist and that the ethnic border between the two parts of the country is marked by a number of irregularities such as ethnic enclaves. To provide some evidence of the potential impact of these irregularities, we omitted settlements from the Northeast part of the Czech Republic characterized by a very ragged ethnic border. ${ }^{26}$

The exclusion of these settlements from the sample has virtually no impact on the estimated effects in $\mathrm{RD}$ analysis (see Table C.4). In the $\mathrm{RD}$ regression the estimated impact of resettlement on the emigration rate is now still 0.6 to 0.7 percentage points, as in the baseline specification, the estimated impact of the emigration rate also remains unchanged at 0.5 percentage points. The impact on net immigration is, however, insignificant. This is in line with other results in the main part of the paper and suggests that results for net immigration rates are somewhat less robust (and limited only to the 1980s) than those pertaining to and net immigration rates.

Figure C.1: Settlements within $15 \mathrm{~km}$ to the ethnic border after omitting Northeast part of the Czech Republic

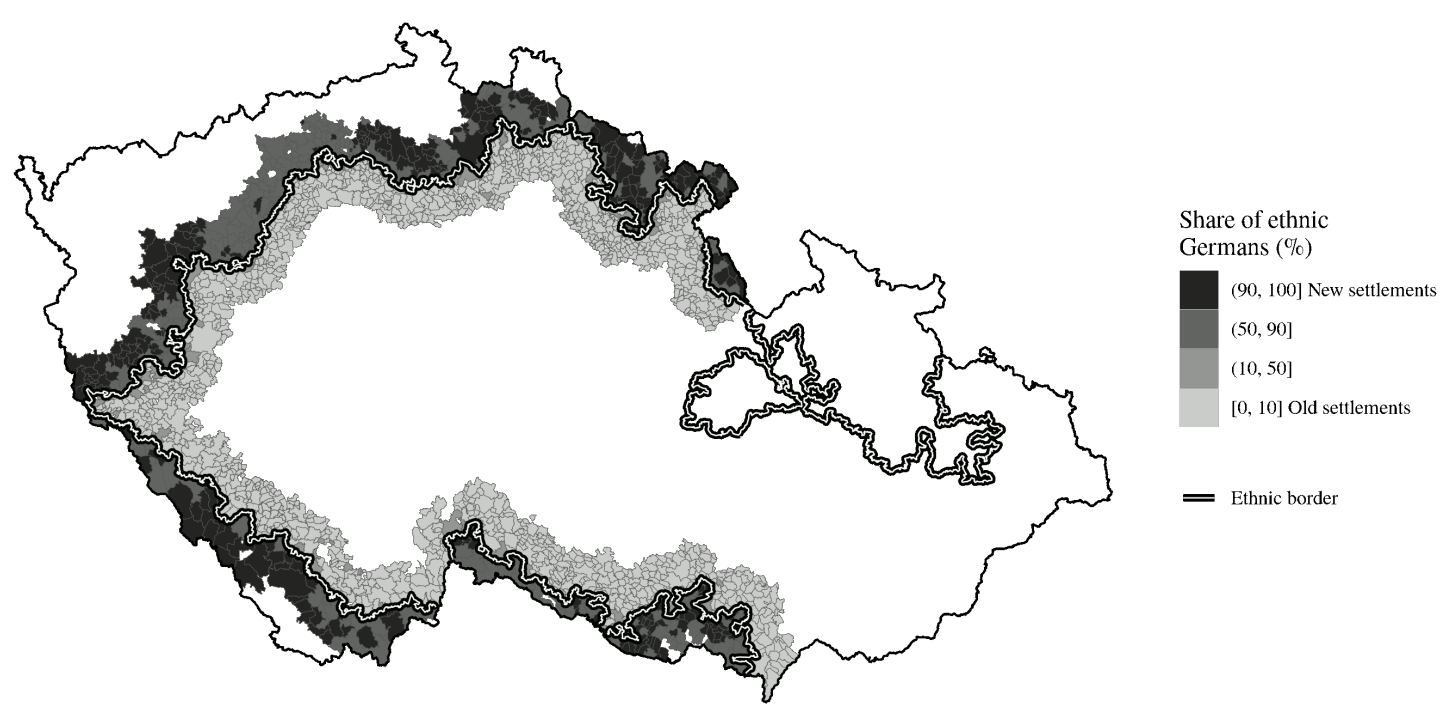

26. For the sample of settlements, included in this robustness check, after the exclusion of Northern Moravia see Figure C.1. 
Table C.4: Robustness test 4: Exclusion of a part of ethnic border characterized by a large number of irregularities

\begin{tabular}{lccc}
\hline & \multicolumn{3}{c}{ Polynomial forcing function } \\
\cline { 2 - 4 } & $1^{\text {st }}$ order & $2^{\text {nd }}$ order & $3^{\text {rd }}$ order \\
\cline { 2 - 4 } & $(1)$ & $(2)$ & $(3)$ \\
\hline \multicolumn{4}{c}{ Dependent variable: } \\
Emigration rate (\%) \\
New settlement (=1) & $0.744^{* * *}$ & $0.655^{* * *}$ & $0.569^{* *}$ \\
Adjusted R2 & $(0.081)$ & $(0.123)$ & $(0.180)$ \\
Observations & 0.152 & 0.152 & 0.152 \\
& 57,763 & 57,763 & 57,763 \\
& \multicolumn{3}{c}{ Dependent variable: } \\
New settlement $(=1)$ & $0.547^{* * *}$ & $0.463^{* * *}$ & $0.501^{*}$ \\
Adjusted R2 & $(0.093)$ & $(0.140)$ & $(0.205)$ \\
Observations & 0.082 & 0.082 & 0.082 \\
& 57,763 & 57,763 & 57,763 \\
& \multicolumn{3}{c}{ Dependent variable: } \\
New settlement $(=1)$ & $-0.197^{*}$ & -0.192 & -0.067 \\
Adjusted R2 & $(0.080)$ & $(0.120)$ & $(0.171)$ \\
Observations & 0.091 & 0.091 & 0.091 \\
& 57,763 & 57,763 & 57,763 \\
\hline
\end{tabular}

Note: Estimates from Equation (3) in the main text. Only settlements within a $15 \mathrm{~km}$ band around the ethnic border are considered. Results control for year fixed effects, an RD polynomial, and region fixed effects, population fixed effect, log of altitude, terrain roughness, and $\log$ of the distance to the country border. Symbols represent statistical significance of differences in means between old and new settlements with $\dagger=p<0.1,{ }^{*}=p<0.05,{ }^{* *}=p<0.01,{ }^{* * *}=p<0.001$. Values in brackets are clustered standard errors. 


\section{C.5 Robustness test 5: Using balanced panel data set}

As noted in the main part of the paper and detailed in Appendix B, we use unbalanced panel data on the settlements to include the maximum number of observations possible. Focusing on this unbalanced data may lead to biased results if there are systematic difference in missing observations of new and old settlements. Since such selectivity cannot be entirely precluded we repeat estimates using a balanced panel of settlements. This was constructed by using only those settlements for which annual observations are available for all years from 1971 to 2015.

Table C. 5 shows the results for the causal impact of resettlement on residential migration based on the matching and RD identification strategies. These results are highly consistent with those reported in the main part of the paper. The matching estimates for the effects on emigration and immigration rates differ by less than 0.1 percentage points from those reported in the main part of the paper. The effects for net immigration rates are, however, statistically insignificant, (except in Version 3 of the results) but quantitatively they very similar to the results reported in the main part of the paper.

$\mathrm{RD}$ analysis results for emigration and immigration rates as well as net immigration rates, are also very similar to results reported in the main part of the paper. The estimated treatment effects once more differ by less than 0.1 percentage points from those in the main part of the paper. 
Table C.5: Robustness test 5: Using balanced panel data set

\begin{tabular}{|c|c|c|c|c|c|c|}
\hline & \multicolumn{6}{|c|}{ Identification strategy } \\
\hline & \multicolumn{3}{|c|}{ Matching strategy } & \multicolumn{3}{|c|}{ RD strategy } \\
\hline & \multicolumn{3}{|c|}{ Matching version } & \multicolumn{3}{|c|}{ RD polynomial } \\
\hline & Version 1 & Version 2 & Version 3 & $1^{\text {st }}$ order & $2^{\text {nd }}$ order & $3^{\text {rd }}$ order \\
\hline & (1) & (2) & (3) & (4) & (5) & (6) \\
\hline & \multicolumn{6}{|c|}{$\begin{array}{l}\text { Dependent variable: } \\
\text { Emigration rate }(\%)\end{array}$} \\
\hline New settlement $(=1)$ & $\begin{array}{l}0.596^{* * *} \\
(0.084)\end{array}$ & $\begin{array}{l}0.636^{* * *} \\
(0.073)\end{array}$ & $\begin{array}{l}0.785^{* * *} \\
(0.055)\end{array}$ & $\begin{array}{l}0.828^{* * *} \\
(0.078)\end{array}$ & $\begin{array}{l}0.784^{* * *} \\
(0.115)\end{array}$ & $\begin{array}{l}0.666^{* * *} \\
(0.166)\end{array}$ \\
\hline Adjusted R2 & 0.214 & 0.241 & 0.251 & 0.212 & 0.212 & 0.212 \\
\hline Observations & 1,860 & 5,556 & 7,044 & 57,974 & 57,974 & 57,974 \\
\hline & \multicolumn{6}{|c|}{$\begin{array}{l}\text { Dependent variable: } \\
\text { Immigration rate }(\%)\end{array}$} \\
\hline New settlement $(=1)$ & $\begin{array}{l}0.471^{* * *} \\
(0.073)\end{array}$ & $\begin{array}{l}0.512^{* * *} \\
(0.079)\end{array}$ & $\begin{array}{l}0.471^{* * *} \\
(0.096)\end{array}$ & $\begin{array}{l}0.478^{* * *} \\
(0.080)\end{array}$ & $\begin{array}{l}0.465^{* * *} \\
(0.115)\end{array}$ & $\begin{array}{r}0.395^{*} \\
(0.172)\end{array}$ \\
\hline Adjusted R2 & 0.128 & 0.109 & 0.148 & 0.094 & 0.094 & 0.095 \\
\hline \multirow[t]{2}{*}{ Observations } & 1,860 & 5,556 & 7,044 & 57,974 & 57,974 & 57,974 \\
\hline & \multicolumn{6}{|c|}{$\begin{array}{c}\text { Dependent variable: } \\
\text { Net immigration rate }(\%)\end{array}$} \\
\hline New settlement $(=1)$ & $\begin{array}{l}-0.125 \\
(0.067)\end{array}$ & $\begin{array}{l}-0.124 \\
(0.066)\end{array}$ & $\begin{array}{l}-0.314^{* * *} \\
(0.090)\end{array}$ & $\begin{array}{l}-0.350^{* * *} \\
(0.068)\end{array}$ & $\begin{array}{l}-0.318^{* *} \\
(0.103)\end{array}$ & $\begin{array}{c}-0.271 \\
(0.143)\end{array}$ \\
\hline Adjusted R2 & 0.120 & 0.145 & 0.159 & 0.101 & 0.101 & 0.101 \\
\hline Observations & 1,860 & 5,556 & 7,044 & 57,974 & 57,974 & 57,974 \\
\hline
\end{tabular}

Note: Estimates from Equations (1) and (3) in the main text. Matching estimates: In Version 1 settlements are matched only if they are located less than $5 \mathrm{~km}$ from each other and their population difference is less than 500 inhabitants. In Versions 2 and 3 these maxima are $10 \mathrm{~km}$ and 250 inhabitants, and $10 \mathrm{~km}$ and 500 inhabitants, respectively. All estimates control for pair fixed effects, year fixed effects, log of altitude, terrain roughness, and log of the distance to the country border. RD strategy: Only settlements within a $15 \mathrm{~km}$ band around the ethnic border are considered. Results control for year fixed effects, an RD polynomial, and region fixed effects, population fixed effect, $\log$ of altitude, terrain roughness, and log of the distance to the country border. Asterisks represent statistical significance of differences in means between old and new settlements with ${ }^{*}=p<0.05,{ }^{* *}=p<0.01,{ }^{* * *}=p<0.001$. Values in brackets are clustered standard errors. 


\section{C.6 Robustness test 6: Including outliers}

In the main part of the paper we excluded the top $1 \%$ of all observations in terms of emigration and immigration rates to avoid using implausible values caused by unobserved shocks. ${ }^{27}$ Our motivation for this was that both the matching results (due to the low number of observations) and the RD estimates (due to few observations directly at the border) may be very sensitive to such outliers. We therefore estimated the matching as well as the RD estimates with and without eliminating such outliers.

Table C.6 presents the results of the matching estimates when including outliers. These suggest that the average effect size increases slightly when including the outliers. Emigration rates from new settlements increased by 0.7 to 0.9 percentage points and statistically significantly (relative to 0.6 to 0.7 percentage points per year in the baseline results). Immigration rates to the new settlements from other regions were, however, also statistically significantly (by 0.6 to 0.7 percentage points, relative to 0.5 percentage points in the baseline results) higher in the new than the old settlements. Net immigration rates, by contrast, although lower in average in the new settlements, do not differ statistically significantly from those of the old settlements in all estimated versions except for Version 3.

Similarly results of the RD analysis (see Table C.6) indicate that depending on the functional form of the RD polynomial, emigration rates were by 0.6 and 0.9 percentage points and statistically significantly higher in new than in old settlements. This is only slightly higher than the 0.6 to 0.7 percentage points in the baseline estimates. The results also suggest that immigration rates to the new settlements from other regions were by 0.4 to 0.7 percentage points and statistically significantly higher in all estimates than in old settlements (rather than 0.4 to 0.5 percentage point in the baseline results). Finally, also the estimated effect of resettlement on net immigration rates are mostly negative but lack statistical significance throughout.

27. Vaněk (1996) discusses an example of such a when he states that 116 settlements were destroyed due to lignite mining in Northwest part of the Czech Republic. 
Table C.6: Robustness test 6: Including outliers

\begin{tabular}{|c|c|c|c|c|c|c|}
\hline & \multicolumn{6}{|c|}{ Identification strategy } \\
\hline & \multicolumn{3}{|c|}{ Matching strategy } & \multicolumn{3}{|c|}{ RD strategy } \\
\hline & \multicolumn{3}{|c|}{ Matching version } & \multicolumn{3}{|c|}{ RD polynomial } \\
\hline & Version 1 & Version 2 & Version 3 & $1^{\text {st }}$ order & $2^{\text {nd }}$ order & $3^{\text {rd }}$ order \\
\hline & (1) & (2) & (3) & (4) & (5) & (6) \\
\hline & \multicolumn{6}{|c|}{$\begin{array}{l}\text { Dependent variable: } \\
\text { Emigration rate }(\%)\end{array}$} \\
\hline New settlement $(=1)$ & $\begin{array}{l}0.707^{* * *} \\
(0.096)\end{array}$ & $\begin{array}{l}0.850^{* * *} \\
(0.074)\end{array}$ & $\begin{array}{l}0.838^{* * *} \\
(0.061)\end{array}$ & $\begin{array}{l}0.884^{* * *} \\
(0.083)\end{array}$ & $\begin{array}{l}0.670^{* * *} \\
(0.124)\end{array}$ & $\begin{array}{l}0.561^{* *} \\
(0.177)\end{array}$ \\
\hline Adjusted R2 & 0.177 & 0.206 & 0.201 & 0.160 & 0.160 & 0.160 \\
\hline Observations & 3,414 & 10,896 & 13,392 & 83,849 & 83,849 & 83,849 \\
\hline & \multicolumn{6}{|c|}{$\begin{array}{l}\text { Dependent variable: } \\
\text { Immigration rate }(\%)\end{array}$} \\
\hline \multirow[t]{2}{*}{ New settlement $(=1)$} & $0.608^{* * *}$ & $0.747^{* * *}$ & $0.585^{* * *}$ & $0.717^{* * *}$ & $0.523^{* * *}$ & $0.412^{*}$ \\
\hline & $(0.088)$ & $(0.091)$ & $(0.085)$ & $(0.100)$ & $(0.139)$ & $(0.197)$ \\
\hline Adjusted R2 & 0.099 & 0.112 & 0.112 & 0.068 & 0.068 & 0.068 \\
\hline \multirow[t]{2}{*}{ Observations } & 3,414 & 10,896 & 13,392 & 83,849 & 83,849 & 83,849 \\
\hline & \multicolumn{6}{|c|}{$\begin{array}{c}\text { Dependent variable: } \\
\text { Net immigration rate }(\%)\end{array}$} \\
\hline New settlement $(=1)$ & $\begin{array}{l}-0.099 \\
(0.053)\end{array}$ & $\begin{array}{l}-0.103 \\
(0.070)\end{array}$ & $\begin{array}{l}-0.252^{* * *} \\
(0.068)\end{array}$ & $\begin{array}{c}-0.167^{*} \\
(0.084)\end{array}$ & $\begin{array}{l}-0.147 \\
(0.120)\end{array}$ & $\begin{array}{l}-0.149 \\
(0.157)\end{array}$ \\
\hline Adjusted R2 & 0.107 & 0.108 & 0.108 & 0.073 & 0.073 & 0.073 \\
\hline Observations & 3,414 & 10,896 & 13,392 & 83,849 & 83,849 & 83,849 \\
\hline
\end{tabular}

Note: Estimates from Equations (1) and (3) in the main text. Matching estimates: In Version 1 settlements are matched only if they are located less than $5 \mathrm{~km}$ from each other and their population difference is less than 500 inhabitants. In Versions 2 and 3 these maxima are $10 \mathrm{~km}$ and 250 inhabitants, and $10 \mathrm{~km}$ and 500 inhabitants, respectively. All estimates control for pair fixed effects, year fixed effects, log of altitude, terrain roughness, and log of the distance to the country border. RD strategy: Only settlements within a $15 \mathrm{~km}$ band around the ethnic border are considered. Results control for year fixed effects, an RD polynomial, and region fixed effects, population fixed effect, $\log$ of altitude, terrain roughness, and log of the distance to the country border. Symbols represent statistical significance of differences in means between old and new settlements with ${ }^{\dagger}=p<0.1,{ }^{*}=p<0.05,{ }^{* *}=p<0.01,{ }^{* * *}=p<0.001$. Values in brackets are clustered standard errors. 


\section{C.7 Robustness Check 7: Estimation of values data using the full set of values for responses}

As a final robustness check we conducted a linear regressions analysis of the values data used in the main part of the paper using the full set of values for responses. These robustness checks suggest that our choice of coding has few consequences for the quantitative results (see Table C.7). The estimated coefficients once more remain insignificant in most cases. The only exceptions being hobbies, health and material conditions in the old cohort. As also found in the main part of the paper the older cohort in new settlements puts a higher value on the importance of hobbies. Furthermore, in contrast to the results in the main part of the paper, the same applies to the importance of material conditions, while the importance given to health is lower in the new settlements. 
Table C.7: Estimation of values data using the full set of values for responses

\begin{tabular}{|c|c|c|c|c|c|c|c|c|c|c|}
\hline & \multicolumn{10}{|c|}{$\begin{array}{l}\text { Dependent variable: } \\
\text { Things and values very important in personal life (Likert scale, } 4 \text { = "Very important", } 1 \text { = "Not important at all") }\end{array}$} \\
\hline & $\begin{array}{c}\text { Nature, } \\
\text { environment }\end{array}$ & $\begin{array}{c}\text { Job, } \\
\text { occupation }\end{array}$ & Relationships & $\begin{array}{c}\text { Faith, } \\
\text { spiritual values }\end{array}$ & Hobbies & Housing & Friendship & Health & $\begin{array}{l}\text { Family life } \\
\text { and children }\end{array}$ & $\begin{array}{c}\text { Material } \\
\text { conditions }\end{array}$ \\
\hline & (1) & (2) & (3) & (4) & (5) & (6) & (7) & (8) & (9) & (10) \\
\hline \multicolumn{11}{|c|}{ Panel A: Young cohort (18-29) } \\
\hline New settlement $(=1)$ & $\begin{array}{l}0.048 \\
(0.106)\end{array}$ & $\begin{array}{c}0.107 \\
(0.091)\end{array}$ & $\begin{array}{c}0.019 \\
(0.117)\end{array}$ & $\begin{array}{c}-0.120 \\
(0.163)\end{array}$ & $\begin{array}{c}0.130 \\
(0.117)\end{array}$ & $\begin{array}{c}0.058 \\
(0.079)\end{array}$ & $\begin{array}{c}0.039 \\
(0.098)\end{array}$ & $\begin{array}{c}-0.074 \\
(0.113)\end{array}$ & $\begin{array}{c}-0.150 \\
(0.149)\end{array}$ & $\begin{array}{c}0.143 \\
(0.102)\end{array}$ \\
\hline Observations & 680 & 680 & 680 & 680 & 680 & 680 & 680 & 679 & 680 & 679 \\
\hline \multicolumn{11}{|c|}{ Panel A: Young cohort (18-29) } \\
\hline New settlement $(=1)$ & $\begin{array}{c}-0.041 \\
(0.114)\end{array}$ & $\begin{array}{c}0.112 \\
(0.235)\end{array}$ & $\begin{array}{c}-0.212 \\
(0.137)\end{array}$ & $\begin{array}{c}-0.154 \\
(0.181)\end{array}$ & $\begin{array}{r}0.320^{*} \\
(0.153)\end{array}$ & $\begin{array}{c}-0.021 \\
(0.099)\end{array}$ & $\begin{array}{c}-0.030 \\
(0.107)\end{array}$ & $\begin{array}{c}-0.082^{\dagger} \\
(0.046)\end{array}$ & $\begin{array}{c}-0.104 \\
(0.103)\end{array}$ & $\begin{array}{r}0.302^{*} \\
(0.141)\end{array}$ \\
\hline Adjusted R2 & 0.030 & 0.013 & 0.017 & 0.091 & 0.002 & 0.013 & 0.012 & 0.040 & 0.125 & 0.048 \\
\hline Observations & 611 & 602 & 609 & 608 & 610 & 611 & 609 & 610 & 610 & 610 \\
\hline
\end{tabular}

Table reports estimated coefficients on an indicator variable for new settlements after controlling for settlement (log of altitude, terrain roughness, log of distance to the country border, region fixed effect, and population fixed effect) and personal (age group, education, labor market status, marital status, household size, and for being born in the settlement of residence) characteristics. Standard errors clustered by settlement are reported in parentheses are : ${ }^{\dagger}=p<0.1,{ }^{* *}=p<0.05,{ }^{* * *}=p<0.01$, ${ }^{* * *}=p<0.001$. Descriptive statistics are the mean and the standard deviations (in parentheses). 


\section{References}

Vaněk, Miroslav. 1996. Nedalo se tady dýchat: Ekologie v českých zemích v letech 1968 až 1989. Praha: Ústav pro soudobé dějiny AV ČR. 


\section{MUNI Econ Working Paper Series (since 2018)}

2019-07 Guzi, M., Huber, P., Mikula, Š. (2019). Old sins cast long shadows: The Long-term impact of the resettlement of the Sudetenland on residential migration. MUNI ECON Working Paper n. 2019-07. Brno: Masaryk University. https://doi.org/10.5817/WP_MUNI_ECON_2019-07

2019-06 Mikula, M., Montag, J. 2019. Does homeownership hinder labor market activity? Evidence from housing privatization and restitution in Brno. MUNI ECON Working Paper n. 2019-06. Brno: Masaryk University. https://doi.org/10.5817/WP_MUNI_ECON_2019-06

2019-05 Krčál, O., Staněk, R., Slanicay, M. 2019. Made for the job or by the job? A lab-in-the-field experiment with firefighters. MUNI ECON Working Paper n. 2019-05. Brno: Masaryk University. https://doi.org/10.5817/WP_MUNI_ECON_2019-05

2019-04 Bruni, L., Pelligra, V., Reggiani, T., Rizzolli, M. 2019. The Pied Piper: Prizes, Incentives, and Motivation Crowding-in. MUNI ECON Working Paper n. 2019-04. Brno: Masaryk University. https://doi.org/10.5817/WP_MUNI_ECON_2019-04

2019-03 Krčál, O., Staněk, R., Karlínová, B., Peer, S. 2019. Real consequences matters: why hypothetical biases in the valuation of time persist even in controlled lab experiments. MUNI ECON Working Paper n. 2019-03. Brno: Masaryk University. https://doi.org/10.5817/WP_MUNI_ECON_2019-03

2019-02 Corazzini, L., Cotton, C., Reggiani, T., 2019. Delegation And Coordination With Multiple Threshold Public Goods: Experimental Evidence. MUNI ECON Working Paper n. 2019-02. Brno: Masaryk University. https://doi.org/10.5817/WP_MUNI_ECON_2019-02

2019-01 Fišar, M., Krčál, O., Staněk, R., Špalek, J. 2019. The Effects of Staff-rotation in Public Administration on the Decision to Bribe or be Bribed. MUNI ECON Working Paper n. 2019-01. Brno: Masaryk University. https://doi.org/10.5817/WP_MUNI_ECON_2019-01

2018-02 Guzi, M., Kahanec, M. 2018. Income Inequality and the Size of Government: A Causal Analysis. MUNI ECON Working Paper n. 2018-02. Brno: Masaryk University. https://doi.org/10.5817/WP_MUNI_ECON_2018-02

2018-01 Geraci, A., Nardotto, M., Reggiani, T., Sabatini, F. 2018. Broadband Internet and Social Capital. MUNI ECON Working Paper n. 2018-01. Brno: Masaryk University. https://doi.org/10.5817/WP_MUNI_ECON_2018-01

ISSN electronic edition 2571-130X

MUNI ECON Working Paper Series is indexed in RePEc:

https://ideas.repec.org/s/mub/wpaper.html 